UNIVERSIDADE DE SÃO PAULO

FACULDADE DE FILOSOFIA, LETRAS E CIÊNCIAS HUMANAS DEPARTAMENTO DE LETRAS CLÁSSICAS E VERNÁCULAS

\title{
OS ANOS DE APRENDIZADO MODERNISTA DE CARLOS DRUMMOND DE ANDRADE
}

GABRIEL PROVINZANO GONÇALVES DA SILVA

SÃO PAULO

2018 
UNIVERSIDADE DE SÃO PAULO

FACULDADE DE FILOSOFIA, LETRAS E CIÊNCIAS HUMANAS DEPARTAMENTO DE LETRAS CLÁSSICAS E VERNÁCULAS

\section{OS ANOS DE APRENDIZADO MODERNISTA DE CARLOS DRUMMOND DE ANDRADE}

GABRIEL PROVINZANO GONÇALVES DA SILVA

Dissertação de Mestrado apresentada ao Programa de Pós-Graduação da Literatura Brasileira do Departamento de Letras Clássicas e Vernáculas da Faculdade de Filosofia, Letras e Ciências Humanas da Universidade de São Paulo.

ORIENTADOR: PROF. DR. IVAN FRANCISCO MARQUES

SÃO PAULO

2018 
Nome: Gabriel Provinzano Gonçalves da Silva

Título: Os anos de aprendizado modernista de Carlos Drummond de Andrade

Dissertação apresenta ao Programa de Pós-Graduação da Literatura Brasileira do Departamento de Letras Clássicas e Vernáculas da Faculdade de Filosofia, Letras e Ciências Humanas da Universidade de São Paulo, para a obtenção do título de Mestre em Letras.

Banca examinadora: 


\title{
RESUMO
}

O trabalho procura reconstituir a produção de Carlos Drummond de Andrade da década de 20 a partir da análise de três eixos interligados: a pesquisa estética em diálogo cerrado com o Modernismo, a investigação da subjetividade e o cadente debate sobre o nacionalismo da época. Trata-se, assim, de propor um percurso mais ou menos contínuo que permita interrogar como esses aspectos foram sendo progressivamente conquistados e articulados pelo poeta mineiro ao longo dos anos 20 e como culminaram em seu primeiro livro, Alguma poesia, de 1930. A hipótese desenvolvida é de que a trajetória resultante da conquista desses aspectos e da publicação do seu livro de estreia representou um momento importante em que ele assimilou influências, experimentou procedimentos e decantou temas. O trabalho visa a sugerir, desse modo, a formação poética do Autor, detendo-se no contexto em que estava inserido e a partir do qual construiu sua obra. A fim de discutir a especificidade desta, o argumento se organiza no sentido compará-la aos desdobramentos do Modernismo do mesmo período.

Palavras-chave: Modernismo brasileiro; Carlos Drummond de Andrade; Alguma poesia.

\begin{abstract}
The work seeks to reconstitute the production of Carlos Drummond de Andrade of the decade of 20 from the analysis of three interconnected axes: the aesthetic research in closed dialogue with the Modernism, the investigation of the subjectivity and the cadent debate on the nationalism of the time. It is a question of proposing a more or less continuous course that allows us to question how these aspects were progressively conquered and articulated by the poet throughout the 1920s and culminated in his first book, Alguma poesia. The hypothesis developed is that the trajectory resulting from the conquest of these aspects and the publication of his debut book represented an important moment in which he assimilated influences, tried procedures and themes. The work aims to suggest the poetic formation of the Author, stopping in the context in which he was inserted and from which he constructed his work. In order to discuss its specificity, the argument is organized to compare it with the developments of Modernism of the same period.
\end{abstract}

Keywords: Brazilian Modernism; Carlos Drummond de Andrade; Alguma poesia. 


\section{SUMÁRIO}

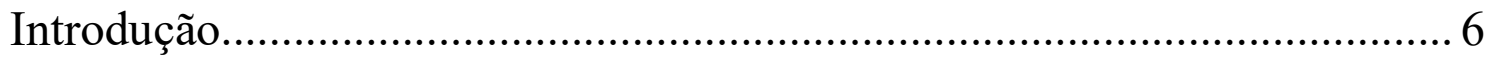

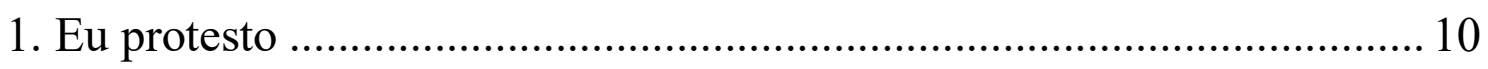

2. Eu não disse ao senhor que não sou senão poeta? ................................. 27

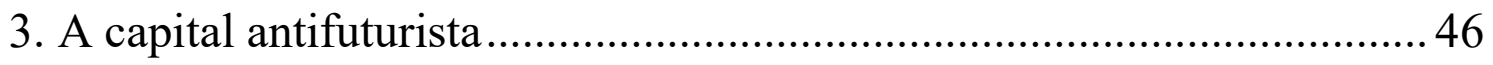

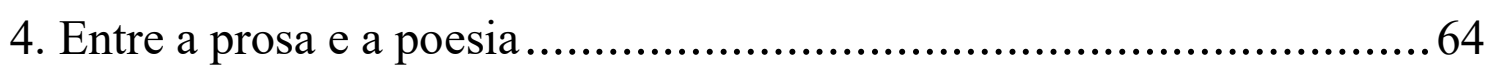

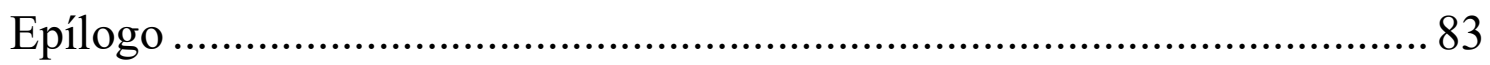

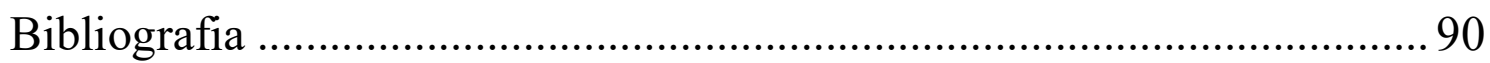




\section{INTRODUÇÃO}

Há oitenta e tantos anos, um jovem poeta mineiro entusiasmado com o Modernismo e já relativamente conhecido pela sua colaboração em jornais e revistas publicava, depois de um período de pelo menos seis anos, em que se acumularam dificuldades práticas e dúvidas pessoais, o seu primeiro livro, Alguma poesia, em 1930. As páginas a seguir tentam reconstruir e historicizar essa trajetória cheia de idas e vindas, analisando seus lances decisivos. A hipótese desenvolvida nelas é de que esse intervalo que se inicia digamos com a primeira carta enviada a Mário de Andrade, em 1924, e que se encerra aproximadamente um ano depois da publicação de seu livro de estreia, com a entrevista concedida ao jornal A pátria, em 1931 - constitui o cerne da temporada de formação do poeta Carlos Drummond de Andrade, como ele próprio, aliás, assumiria. De fato, o intervalo que separa o provinciano remetente que começa a se corresponder com o autor de Paulicéia desvairada do consolidado poeta modernista entrevistado em 1931 (chamado pelo jornal de "um dos epígonos do modernismo nas terras inconfidentes") é bastante movimentado. Nele assistimos, de um lado, ao árduo aprendizado das palavras e técnicas, à exploração desbragada de procedimentos e temas e à difícil assimilação das influências externas, sobretudo a de Mário; e de outro, correlatamente, aos desdobramentos do debate modernista, com sua dinâmica aceleradíssima, na passagem da década de 20 para a de 30. Acompanhar esse movimento de mão dupla significa, portanto, tentar desvendar os nexos entre a experiência poética mais íntima e o aceso debate da época, buscando por eventuais refrações, confluências e divergências, latentes ou manifestas, desse processo tortuoso. Trata-se de sugerir, não um desenvolvimento linear, mas um percurso mais ou menos contínuo de soluções e impasses dentro da produção de Drummond entre a década de 20 e o começo da de 30. Este trabalho propõe, em suma, uma coerência possível para o que o próprio poeta mineiro chamou de "dez anos de lirismo desenfreado" ${ }^{1}$.

Esse percurso, tal como o concebemos, está intimamente atrelado à investigação da subjetividade. Como veremos, essas questões permeiam a produção de Drummond do

\footnotetext{
${ }^{1}$ Lélia Coelho (org.), Carlos \& Mário: correspondência entre Carlos Drummond de Andrade - inédita e Mário de Andrade: 1924-1945. Rio de Janeiro: Bem-Te-Vi, 2002, p. 263.
} 
período e atravessam o conjunto de Alguma poesia, que foi o resultado da arrumação desses escritos. Na verdade, a preocupação com essas questões se articulou com a intensa experimentação formal e temática promovida pelo poeta mineiro nessa época, compondo uma aventura poética em que se combinaram a sondagem da interioridade e a pesquisa estética - e é nessa combinação justamente que reside a afinidade profunda entre o poeta e o Modernismo, daí a pertinência de analisá-los em conjunto. Tentar apreender a articulação entre o egotismo enraizado da produção de Drummond e as conquistas modernistas exige interrogar as mediações existentes entre a formação poética dele, de um lado, e a do próprio Modernismo, de outro, com ganhos para a compreensão de ambos. Esta perspectiva dupla também permite discutir o individualismo do Autor. Como procuraremos argumentar, o seu individualismo equivale, não a isolamento ou alheamento, mas a um modo peculiar de diálogo com autores e questões. De fato, o individualismo do poeta mineiro se determinou como tal a partir da interlocução criteriosa, da polêmica acirrada e do atrito. Ele se define, assim, em confronto com a alteridade, que está entranhada como uma mediação necessária para sua própria constituição. Ou seja, embora se defina como a diferença da algo que lhe é externo, a identidade depende em última análise deste para se afirmar. Daí que nosso Autor tenha participado ativamente do debate modernista do período, por meio de intervenções em jornais - duas são analisadas neste trabalho, "Ta'i!", artigo de 1925 publicado no "Mês modernista", e a entrevista de 1931 - e, de maneira mais mediada, de poemas - os estudados, por serem os mais significativos para os nossos objetivos, são "Explicação", de 1926, "Belo Horizonte", de 1927, "Jardim da praça da Liberdade", de 1926, e "Outubro 1930", de 1931. Apesar de serem de naturezas muito distintas entre si - além deles, recorremos a trechos da correspondência, a elementos da biografia, a dados e a livros da época -, esses textos se constelam, formando uma trajetória em que a pesquisa estética se entronca com a da subjetividade e em que o diálogo com o Modernismo está cifrado concretamente.

Esse diálogo se estreitou progressivamente ao longo da segunda metade da década de 20. A despeito da afinidade profunda, Drummond não nasceu modernista, mas se tornou modernista à medida que se aproximou de Mário de Andrade e da catequese promovida por este via correspondência. Com efeito, as cartas de Mário foram decisivas para que o poeta mineiro abandonasse o universalismo abstrato da juventude e se convertesse ao modernismo e - com muitas ressalvas - ao nacionalismo. Mais à frente nos 
deteremos nesse processo, mas, por agora, importa assinalar que ele trouxe consigo um ingrediente novo para o lirismo do poeta mineiro: a investigação da nacionalidade. Quer dizer, à pesquisa estética e à sondagem da subjetividade se somou o interesse pelo país de origem, que até então inexistia devido ao seu afetado cosmopolitismo. A investigação da nacionalidade constitui, como se sabe, um tópico modernista central e estava, naquele momento em particular, na agenda do dia. Portanto, ao adentrar o debate em torno do nacionalismo, Drummond se colocava do lado de dentro do arraial modernista, como participante de um grande diálogo com seus pares. A mudança teve consequências importantes para sua obra da época, na medida em que a investigação da nacionalidade foi incorporada, não como elemento externo, mas interno, tendo se associado intimamente às pesquisas subjetivas e estéticas. Ou seja, nosso Autor procurou sintonizar a experimentação estética à busca pelas raízes nacionais e estas à identidade individual, armando entre elas uma homologia fundada no gauchismo do poeta e de seu verso (seco, duro e antimelódico), de um lado, e nas singularidades do Brasil, muito distinto dos países europeus que nos serviam de modelo, de outro. Através dessa curiosa homologia, Drummond pôde internalizar as contradições objetivas do seu país para reinventá-las liricamente no âmbito literário. Como veremos, essas contradições foram acessadas por ele através da exploração em profundidade da incipiente modernidade mineira em que estava inserido. Tratava-se, assim, de um processo de particularização, construído com o recurso, de um lado, a elementos autobiográficos e, de outro, ao ritmo pachorrento e tedioso da modernização mineira em que estava localizado. Por meio dessa junção delicada e nada óbvia, Drummond equacionou a subjetividade irredutível, a pesquisa estética e a impregnação nacional, o que constitui um dos alicerces e uma das forças da sua obra da época.

Tentar compreender os anos de formação de Drummond e as raízes do seu primeiro lirismo representou para esta pesquisa um aprendizado difícil e lento que só foi possível graças à ajuda recebida ao longo do processo. Para conclui-la, eu fui beneficiado com uma bolsa de estudos concedida pela CAPES e tive a boa sorte de contar com o diálogo e com a compreensão de muita gente, que preciso agradecer:

Ao meu orientador, Ivan Francisco Marques, exemplo crítico, pelo diálogo franco e pela paciência com meus atrasos; 
A Iumna Maria Simon e a Simone Rossinetti Rufinoni, pela participação na banca, pela leitura atenciosa, pelas sugestões e críticas;

Ao Vinicius Dantas, pelas conversas tão breves quanto instigantes;

Ao Paulo Ramos, pela escuta afiada;

Ao Marcos, Luiz, Euclides, Lucas, Hugo, Natália, Vitor, Antônio, Clarisse, Ivan, Raúl, Rafael, Mariana, Tainá, Lucas Martins, Ricardo, Iara, Gabriela, Marianne, Guilhermy, Guilherme, Vitão, pela amizade, pelos botecos e cervejas;

Ao Homero, Henrique e Elisa, pela astrologia, pelos carnavais e pela viagem inesquecível;

Aos moradores João Vitor, Bruna, Henrique e Gabrielle, por fazerem da nossa casa a nossa casa;

À minha irmã Stella, pela parceria no Edifício Isaura;

Ao meu pai e à minha mãe, pelo apoio incondicional;

$\mathrm{A} \mathrm{Ju}$, pelo encontro inesperado, mas fulminante, com amor;

À minha avô Nice, in memoriam. 


\section{CAPÍTULO 1}

\section{EU PROTESTO (1925)}

"Ta'i!" foi publicado no jornal carioca $A$ noite em 29 de dezembro de 1925. Embora hoje esteja praticamente esquecido, o artigo é peça importante porque representa uma virada dentro da formação de Drummond, pois, a despeito da sua tibieza, ele formula pela primeira vez questões e problemas que ocuparam seu Autor ao longo de toda a segunda década de 20 e que estão no centro do seu livro de estreia, Alguma poesia, de 1930. Trata-se, assim, da primeira tentativa sistemática de encarar a problemática posta em pauta pelo Modernismo e a todo vapor naquele momento. Nesse sentido, as suas inconsistências - que certamente contribuíram para o seu esquecimento precoce - são reveladoras das dificuldades e dúvidas do poeta mineiro diante do debate modernista. Voltar a elas, portanto, pode ser um bom ponto de partida para refazer o percurso do poeta mineiro ao longo dos anos 20.

"Ta'i!" foi a terceira colaboração do Autor ao chamado "Mês modernista", uma espécie de dossiê da literatura modernista, em que, além de Drummond, colaboraram Mário de Andrade, Sérgio Milliet, Martins de Almeida, Manuel Bandeira e Prudente de Morais, neto. A ideia de criação do "Mês modernista" partiu do então diretor do jornal, Viriato Correia, escritor ligado ao Parnasianismo que, a pretexto de entrevistar Mário em dezembro do mesmo ano (a entrevista resultante seria a célebre "Assim falou o papa do futurismo"), propôs a este a criação de um "Mês futurista" - nome pelo qual o Modernismo era conhecido na época sobretudo entre seus detratores. Apesar da provocação implícita do título, Mário se empolgou com a proposta, mas exigiu a troca do nome do mensário, pois não aceitava escrever com a "taboleta" de futurista. O jornal então cedeu à exigência do escritor, porém anunciou a empreitada como o "mês modernista que ia ser futurista" para não perder a piada. Ao que consta, Mário foi o responsável por definir os nomes dos participantes. E de fato, a opção por nomes de diferentes regiões do país - Mário e Sérgio Milliet de São Paulo; Manuel Bandeira e Prudente de Morais, neto do Rio de Janeiro; Drummond e Martins de Almeida de Minas Gerais - parece ter tido o objetivo de reunir uma amostragem nacional do Modernismo, que àquela altura não estava mais restrito a São Paulo e ao Rio de Janeiro e que, pelo contrário, se irradiara para diferentes regiões do país. Indiretamente, a opção atesta a vitalidade do Modernismo, o 
qual, apesar de muito restrito, já começava a alcançar escritores de diferentes localidades. $\mathrm{Na}$ verdade, o episódio como um todo sugere uma mudança sensível na forma como o movimento era visto fora do diminuto circuito de simpatizantes. O convite do jornal a um grupo de jovens escritores que se identificavam como modernistas não deixa de ser um indício de que, naquele momento, a recusa violenta dos primeiros anos da década de 20 dera lugar a uma curiosidade não completamente destituída de escárnio e de má vontade. Exemplo dessa atitude ambígua, o mais provável é que o jornal carioca estivesse menos interessado na produção desses autores do que em um eventual escândalo, que pudesse alavancar as tiragens e impulsionar as vendas, haja vista suas manchetes escarninhas e sensacionalistas.

Mário sabia de tudo isso, mas pensava que os modernistas poderiam aproveitar a oportunidade para expressarem suas posições e publicarem seus escritos. Pragmático, ele queria usar para a causa modernista o jornal que os queria usar para fabricar escândalos e vender mais. Nas cartas que enviou a Drummond convidando-o e insistindo para que aceitasse a proposta, o autor de Paulicéia desvairada reconheceu o aspecto de caçoada do convite, mas diminuiu sua importância para valorizar a liberdade para colaborar com o que quisesse e os "cobres" que a colaboração renderia. O lado financeiro deve ter pesado, porque nenhum dos colaboradores do "Mês modernista" - nem mesmo Mário de Andrade, o mais conhecido entre eles - vivia naquele momento do que escrevia, cada um tocando a literatura paralelamente a outras funções, e que quase todos publicariam nos anos seguinte livros às próprias custas, devido às dificuldades para editar, - fato provavelmente decisivo para a aceitação do convite. No caso de Drummond, tratava-se de um "moço pessoalmente sem meios"2, que, embora trabalhasse como jornalista no Diário de Minas, ainda vivia da mesada do pai e que custearia com dinheiro do próprio bolso a publicação do seu primeiro livro, Alguma poesia, cinco anos depois. Os interesses envolvidos no episódio não poderiam ser mais desencontrados. Do lado do jornal, tratavase de tentar faturar em cima da fama polêmica dos escritores modernistas; e do lado destes, tratava-se de aproveitar a oportunidade inédita de publicarem seus escritos e de serem pagos por isso. Para medir o ineditismo do episódio, vale lembrar que o dinheiro da colaboração foi o primeiro relacionado à literatura que receberam, por exemplo,

\footnotetext{
${ }^{2}$ Lélia Coelho (org.), Carlos \& Mário: correspondência entre Carlos Drummond de Andrade - inédita - $e$ Mário de Andrade: 1924-1945. Rio de Janeiro: Bem-Te-Vi, p. 132.
} 
Drummond $^{3}$ e Manuel Bandeira ${ }^{4}$, então com quarenta anos e com três livros publicados (!). O comportamento do jornal, enfim, espelha a desconfiança com que os modernistas eram encarados pelo público mais amplo de leitores da época (que, por sua vez, também era minoritário em relação ao número de analfabetos) e dá a ver o isolamento em que produziram suas obras, vistas como manifestações excêntricas e arbitrárias, porque descoladas do restante da sociedade.

Em "Ta'i!", Drummond - anunciado como "um dos generais do futurismo de Minas" - assume a provocação do jornal e forja um tom desabusado em que se misturam polêmica e galhofa. O parágrafo de abertura é um petardo de picardia:

Me parece que o modernismo brasileiro precisa abandonar de todo o respeito de papão da tradição (não confundir com Capão da traição). Vou dizer porque. Evidentemente, não posso negar o passado: um enforcado não pode negar a corda que lhe aperte o pescoço. Mas tenho o direito de declarar que a corda está apertando demais, puxa! E que o melhor é cortá-la duma vez. A boa gente do passadismo não deixa a tradição descansar... E tradição pr'aqui, tradição pr'acolá... E vai o modernismo faz uma bruta espinafração com os bonecos bobos e bambos do passadismo e depois põe a mão no queixo, imaginando: "É... na tradição não convém mexer não. Tão mofina coitadinha!" E toca a ajeitar o fiozinho escasso da pobre, com medo que ele estique e arrebente. Tomara que arrebentasse! $!^{5}$

\footnotetext{
${ }^{3}$ Em nota anexada à edição da correspondência com Mário que organizou, Drummond diria sobre a remuneração: "também para mim os duzentos mil-réis ganhos com a colaboração na Noite, durante quatro semanas, eram novidade extraordinária, o que explica o meu açodamento em embolsá-los". Id., Ibid., p. 186.

${ }^{4}$ Manuel Bandeira lembraria do episódio nos seguintes termos: "a princípio não quis aceitar o convite, porque me pareceu que a gente d'A Noite, cujo diretor na ocasião era Viriato Correia, ia apresentar-nos um pouco como o Sarrasani exibia no circo os seus elefantes ensinados. Mário respondeu-me: "Vocês estão fazendo chiquê [sic] com A Noite. Aceitem isso logo! Liberdade de escrever o que quiser. Eu pretendo pedacinhos vivos, porém sem importância, é lógico. Importância de meia coluna. Acho que vocês devem aceitar". Afinal concordei em colaborar e a respeito dos elefantes Mário me escreveu: "Se você me dá os elefantes do Circo Sarrasani pra mim, faço uma das meias colunas com isso. É um bom jeito de mostrar que a gente não cai na esparrela e em última análise nada mais somos que elefantes ensinados, nós artistas. Deixe de ser historiento, que é isso mesmo!". Não levei muito a sério o 'Mês Modernista': o que fiz foi me divertir ganhando cinquenta mil-réis por semana, o primeiro dinheiro que me rendeu a literatura". Manuel Bandeira, "Itinerário de Passárgada". In: _. Poesia completa e prosa. Rio de Janeiro: Editora Nova Aguilar, 1985, p. 77. Vale lembrar que Mário efetivamente aproveitaria os elefantes em uma de suas colaborações. Cf. Mário de Andrade, " Monólogo dum elefante do circo Sarrasani". In: Marta Rosseti Batista, Telê Porto Ancona Lopez e Yone Soares de Lima (orgs.), op. cit., pp. 247-248.

${ }^{5}$ Carlos Drummond de Andrade, “Ta'i!". In: Marta Rosseti Batista, Telê Porto Ancona Lopez e Yone Soares de Lima (orgs.), Brasil: $1^{\circ}$ Tempo Modernista - 1917/29, São Paulo: Instituto de Estudos Brasileiros, 1972, p. 258.
} 
O parágrafo se inicia com um pronome oblíquo que é um desafio às normas gramaticais e que é só a primeira das suas excentricidades. Ele se caracteriza por uma ânsia de transgredir normas e confrontar modelos que resulta na mistura peculiar de provocação e confusão que o define. É o que ocorre, por exemplo, na primeira oração com o uso da preposição "de" antes do complemento de objeto direto "papão da tradição". O uso gera uma dificuldade de compreensão, pois obscurece a relação existente entre os termos "respeito" e "papão da tradição". Quer dizer, a preposição isolada não permite saber se o "respeito" é $d o$ "papão da tradição", isto é, se tem o sentido de pertencer a este ou se o verbo "respeitar" está usado como sinônimo de "recear" e quer dizer algo como: o modernismo brasileiro deveria abandonar de todo o receio de ser um papão da tradição (neste caso, haveria a elipse do verbo "ser"). A construção é ambígua, porque comporta duas leituras distintas. Com essa ambiguidade, tratava-se de contrariar a correção gramatical e, por extensão, os modelos retóricos e acadêmicos vigentes e contra os quais o Modernismo se rebelou - aí a convergência profunda entre o artigo e o movimento. No plano do léxico, esse espírito polêmico se expressa na escolha de termos inusitados, o mais gritante dos quais é o "papão da tradição". A presença do termo oriundo do universo infantil gera um efeito cômico que dá o tom descontraído do artigo. É por isso que a referência ao Capão da traição logo na sequência surpreende, visto que se trata de um conhecido (e sangrento) episódio da história nacional que nada tem a ver com papões e afins. No contexto, a referência funciona como um alerta para que seu leitor não confundisse "papão da tradição" com "Capão da traição", por causa da semelhança fonética existente entre eles. Porém, a sua presença é estranha, porque se choca com termos de origem muito distintas, configurando uma mistura incongruente e confusa. Essa aproximação de termos de campos tão distintos acaba desnorteando o seu leitor, que não sabe exatamente do que trata o artigo.

Na segunda oração, o Autor - consciente provavelmente da confusão - se propõe a explicar o que afirmara apenas de maneira atabalhoada na primeira: "vou dizer porque [sic]". Porém, a conjugação do verbo na primeira pessoa do singular (que faz pensar em uma certa arbitrariedade da argumentação), de um lado, e o uso do termo "porque" no lugar do esperado "por quê", de outro, põem a explicação sob suspeita. E realmente, a explicação dada é inusitada porque consiste em uma comparação. Drummond usa a imagem de um enforcado, a quem se compara por se sentir asfixiado pela tradição. Mas, embora anticonvencional e, nesse sentido, interessante, a imagem não contribui muito 
para explicar o que o Autor efetivamente entendia por tradição e qual seria sua função, ficando no nível muito geral de que não deveria asfixiar ou imobilizar o presente. Vista de hoje, a impressão que fica é a de uma polêmica divertida, mas superficial e, em certo sentido, até calculada, pois ia de encontro aos interesses do jornal. Não obstante, a polêmica armada no artigo também tinha um papel estratégico em outro sentido, porque tocava no nervo do candente debate modernista da época, que era justamente a questão da tradição brasileira. Ao abordá-la, mesmo que canhestramente, Drummond se inseria no intenso empenho modernista de discutir e reavaliar a cultura brasileira. "Ta'i!" entroncava, por esse lado, no esforço de escritores como Oswald de Andrade e Mário de Andrade, que vinham tentando criar uma tradição nacional e moderna que não abstraísse completamente o passado, até porque este não fora superado e andava de mãos dadas com o presente - vale lembrar que a efervescência da cidade de São Paulo nos anos 20 estava diretamente relacionada à alta do café no mercado externo, cuja aristocracia fazia parte dos círculos modernistas. Mas, apesar de igualmente extraordinárias, as saídas aventadas por Oswald e Mário diferiam bastante.

Com a publicação de Pau Brasil, também de 1925, Oswald de Andrade inventou uma solução estética e cultural para o Brasil. No livro, o dado local é violentamente desrecalcado e incorporado aos poemas. Ou melhor, a sua matéria-prima é obtida "mediante duas operações: a justaposição de elementos próprios ao Brasil-Colônia e ao Brasil burguês, e a elevação do produto - desconjuntado por definição - à dignidade de alegoria do país"6. Ou seja, a persistência de elementos do Antigo Regime colonial misturados com a vida cotidiana representa do ponto de vista pau-brasil, não dilaceramento ou dualidade, mas uma imagem outra do progresso, sui generis e "inocente"7, pois nele convivem passado, presente e futuro. Essa convivência reúne, portanto, coordenadas opostas: o país é atrasado e, por isso mesmo, é moderno. A poesia pau-brasil desarma, assim, todos os antagonismo e conflitos, transformando-os em outras tantas vantagens de um país conciliador e apaziguado. O progresso à brasileira reside precisamente nesse congraçamento entre os contrários; entre colonizadores e colonizados; mulatos, brancos e negros; motorneiros, bacharéis e carroceiros; choferes e

\footnotetext{
${ }^{6}$ Roberto Schwarz, "A carroça, o bonde e o poeta modernista", in: Que horas são?. São Paulo: Companhia das Letras, 2002, p. 24. O argumento do parágrafo se apoia nos ensaios de Schwarz e de Vinicius Dantas. Cf. Vinicius Dantas, "Oswald de Andrade e a poesia". In: Novos Estudos. São Paulo: CEBRAP, no 30, julho 1991, pp. 191-203.

${ }^{7}$ Roberto Schwarz, op. cit., p. 24.
} 
procissões; prostitutas e famílias; cidadezinhas históricas de Minas e postes da Light; enfim, entre modernidade e atraso em todas as suas variações. Esta a "inversão positivadora"8 $^{8}$ que determina o tratamento simpático e familiar, engraçado e condescendente da matéria brasileira. Nesse sentido, o encanto natural e simples da linguagem dos poemas do livro - livre dos "cipós da metrificação" e munida da "contribuição milionária de todos os erros"9 - reflete a convivência harmoniosa dos contrários, os quais se encontram cordialmente na prosa dos primeiros cronistas, no âmbito da colocação pronominal, no bonde, em fazendas, diante de campos atávicos etc., mas também no espaço urbano, em particular em São Paulo, cidade cuja representação foi importantíssima dentro do Modernismo, sobretudo nos primeiros anos, como se sabe.

Mário também estava naquele momento matutando em uma modernidade que afinasse com sua "pátria tão despatriada"10 ${ }^{10} \mathrm{Na}$ entrevista que concedeu a Viriato Correia no mesmo jornal onde alguns dias depois saiu "Ta'i!", sentenciara:

$$
\begin{aligned}
& \text { nós só seremos de deveras uma Raça o dia em que nos } \\
& \text { tradicionalizarmos integralmente e só seremos uma Nação quando } \\
& \text { enriquecermos a humanidade com um contingente original e nacional } \\
& \text { de cultura }{ }^{11} \text {. }
\end{aligned}
$$

Ou seja, como na operação pau-brasil - mas sem o triunfalismo desta -, tratava-se de imaginar um progresso avesso à norma, além de mais humano, de acordo com as singularidades do país e com suas tradições íntimas, populares e unânimes, para que não precisassem ser condenadas à extinção. A ideia de progresso idealizada por Mário naquele momento como que dependia, portanto, de uma volta ao passado e da tradicionalização deste, com o que emergiria a consciência nacional a qual nos facultaria a entrada no mundo moderno. Logo, ao invés de uma posição subalterna resignada a copiar a cultura de outros países, o que Mário estava propondo era uma profunda viravolta, a que não faltava a nota otimista: para ingressar na modernidade, dependíamos da constituição de uma identidade própria, que por sua vez estava ligada ao passado do país, e não de

\footnotetext{
${ }^{8}$ Vinicius Dantas, "Oswald de Andrade e a poesia", cit., p. 197.

${ }^{9}$ Oswald de Andrade, Pau Brasil, São Paulo: Globo, 2004, p. 29.

${ }^{10}$ Expressão cunhada por Mário no poema "Louvação da tarde". Cf., "Louvação da tarde". In: Mário de Andrade, Poesias completas. Edição crítica de Diléia Zanotto Manfio, Belo Horizonte; São Paulo: Itatiaia; Editora da Universidade de São Paulo, 1987, p. 145.

${ }^{11}$ Mário de Andrade, “Assim falou o papa do Futurismo (1925)”. In: Marta Rosseti Batista, Telê Porto Ancona Lopez e Yone Soares de Lima (orgs.), op. cit., p. 236.
} 
macaquear o que nos vinha de fora. Tratava-se, enfim, de uma visão tradicionalista do progresso, mas que nem por isso se opunha à influência estrangeira, que se assimilada criticamente poderia contribuir para o alargamento do país.

Mário estava pensando - aliás, como Oswald - em termos de uma identidade nacional, da qual "nossas pequenas mas nobres tradições"12 ${ }^{12}$ seriam partes constitutivas. Tomando o concerto das nações como um sistema mundial de contribuições nacionais, o autor de Remate de males defendia que só seríamos uma Nação (com maiúscula!) quando fôssemos capazes de enriquecer a humanidade com um contingente original de cultura, daí a necessidade de sistematizar e tradicionalizar o passado, isto é, de referi-lo ao presente. Já o sentido antitradicional dado por ele à tradição se devia às carências do país, razão também pela qual o ímpeto de prolongá-la vinha acompanhado desde dentro da defesa da liberdade em relação a ela, o que explica a intensa experimentação que Mário promoveu ao longo de toda sua vida e obra ${ }^{13}$. O esforço tanto de Mário quanto de Oswald neste momento era, em última análise, portanto, o ajuste ou a conciliação entre o passado e o presente a fim de integrar culturalmente o país. Em ambos, porém, a tentativa não ia sem ambiguidades. Trocando em miúdos, é claro que, de um lado, a hipótese de um nacionalismo que se fecundasse com a influência europeia sem abrir mão da herança herdada do passado e, de outro, o ato de desrecalcar e articular elementos até então abafados pelo bom gosto parnasiano e de modo mais amplo pela ideologia colonialista, atribuindo-lhes ademais enérgico sinal positivo, constituem plataformas de onde era possível criticar a norma burguesa, ainda mais no contexto tacanho dos anos 20 , com o que se inserem inequivocamente no campo crítico. Mas também é impossível hoje ignorar

\footnotetext{
12 A expressão é do próprio Mário e é citada por Vinicius Dantas. Cf. "Desmanchando o naturalismo: capítulos obscuríssimos da crítica de Mário e Oswald". In: Novos Estudos. São Paulo: CEBRAP, n 57, julho 2000, p. 23.

${ }^{13}$ Para o comentário de Schwarz sobre o sentido da tradição em Mário, Roberto Schwarz, "Os sete fôlegos de um livro". In: __, Sequências Brasileiras: ensaios, São Paulo: Companhia das Letras, 1999, p. 48. Para medir o anti-tradicionalismo de Mário, vale a pena compará-lo com o tradicionalismo de Gilberto Freyre: "Gilberto, preso à sociedade açucareira do Nordeste, prefere defender a tradição, afirmando que o caminho da modernidade está na sabedoria portuguesa de equilibrar os antagonismos e conservar os elementos e as transformações "que atuaram de modo criador no desenvolvimento nacional". Interpreta a realidade social como "participante íntimo e ativo dos valores do grupo" - mas acrescenta com cautela - "criticamente e também com simpatia humana". Constrói a imagem do Brasil através da vivência regional e aceita, de bom grado, que o classifiquem como um "realista romântico". Mário, ao contrário, procura evocar ou reviver o passado sem o transformar numa visão saudosista; sabe o quanto ele pesa em nossos gestos, mas prefere tradicioná-lo em valor atuante e referido ao presente. Não é um aristocrata, mas um homem comum, urbano, pragmático, que insiste em se confessar sem memória - pessoal ou de grupo - para dissolver melhor as particularidades locais numa concepção ampla de nacionalismo". Gilda de Mello e Souza, "O mestre de Apipucos e o turista aprendiz". In: _, A ideia e o figurado. São Paulo: Livraria Duas Cidades/Editora 34, 2005 , p. 51.
} 
o que há de ingênuo, no caso de Mário, na aposta num progresso que nos aproximaria de um idealizado passado pré-burguês e que daria continuidade às suas tradições, e de problemático, no de pau-brasil, na utopia de um projeto sustentando valorização do café na bolsa. Há, em resumo, algo de inocente nas ideias de progresso aventadas por Mário e Oswald, embora com uma diferença de graus evidente. Com efeito, a forma angustiada e aporética com que a questão aparece na obra de Mário em geral (mas não em "Assim falou o papa do futurismo", cujo otimismo reflete o mesmo clima de época que está presente na proposta de Oswald) é bastante diversa da euforia com que a poesia pau-brasil avaliava a permanência de estruturas derivadas do nosso patriarcado rural.

Não menos ambígua era a relação do autor de "Ta'i!" com a tradição e com o passado. No artigo publicado em $A$ Noite, Drummond articula o ataque ao passadismo e à tradição - que, para ele, compunham uma só e mesma coisa - a uma inusitada defesa do princípio da evolução e do Modernismo, que encarnaria esse princípio. Segundo ele, "graças a Deus" não existia uma tradição brasileira e, portanto, não fazia sentido se prender e medir por escritores e modelos do passado. O que de fato existia era, de um lado, a cultura popular - verdadeiramente nacional e por isso valiosa - e, de outro, o "nosso fenômeno literário" - a seu ver, todo errado e chocho, o que fica claro já ao se referir ao conjunto da literatura brasileira como um fenômeno, frisando sua falta de organicidade. Graças a essa concepção, a reflexão sobre a tradição em "Ta'i!", ao invés de assumir o sentido de uma falta ou de um déficit, aparece destituída de sua carga negativa e ganha contornos auspiciosos, em um tom que lembra muito o de Mário na entrevista "Assim falou o papa do futurismo". O tratamento dado à questão no artigo é lépido e engraçado, como se nosso Autor vislumbrasse nessa ausência, não o drama com o qual o intelectual brasileiro tinha necessariamente que se haver, mas a garantia de liberdade para criar uma tradição autêntica, livre de constrangimentos passadistas e inspirada nas criações populares. A posição do Autor no artigo, mais do que ecletismo, reúne elementos contraditórios, porque se se declara anti-passadista e anti-tradicionalista, ele não rejeita completamente o passado ("sofro a pressão atmosférica do passado"); e se se confessa evolucionista, ele reconhece em seguida que o evolucionismo também é um passadismo, o que a rigor deveria desautorizá-lo ("ao princípio dissolvente da tradição devemos opor o princípio construtivo de evolução. Não me digam que também é passadismo. Eu sei que é"). Menos do que problemas - o que certamente também eram, mas não para o próprio Autor, que os testava no grande laboratório que foi "Ta'i!" - esse vaivém estava na raiz da 
posição que o jovem Drummond estava tentando elaborar e que era diversa tanto das convencionais (o tradicionalismo ou o evolucionismo estritos, por exemplo) quanto das de Mário ou de Oswald, como se experimentasse - salvo engano - pela primeira vez a oscilação entre o respeito discreto à obra dos antepassados e a blague ou a ironia; entre a tradição popular e a literária; entre o evolucionismo e o passadismo; entre a influência europeia e a defesa de uma arte autenticamente nacional - oscilações que vão reaparecer com insistência em seus escritos da segunda metade da década de 20.

Mário percebeu a singularidade de "Ta'i!" e em carta a Drummond de janeiro de 1926 o criticou:

do seu último [artigo] gostei menos. Discordo de você sobre tradição. Isto é, não sei se discordo propriamente. Meia coluna vi que não dava bem pra você esclarecer bem o conceito de tradição e o emprego dela que repudiava. Você leu a minha entrevista n'A Noite? Lá estabeleci a maneira de tradição pra qual sou favorável. Que emprego e que aliás você também emprega e nem que não queira há de sentir fatalmente, como prova o "Sabará"14.

Com a franqueza habitual e programática, Mário discordava do amigo, sem tentar impor a ele o seu próprio tradicionalismo anti-tradicional - que, no entanto, era uma das influências do artigo. A despeito das diferenças, a grande influência de "Ta'i!" eram as cartas de Mário e, em particular, a sua entrevista para $A$ noite. Na verdade, a questão da tradição e do nacionalismo constituía uma velha querela entre os amigos, tamanha eram as discordâncias sobre o tema quando do começo da correspondência. Com efeito, na primeira carta que enviou ao amigo, em 28 de outubro de 1924 (praticamente um ano antes do artigo, portanto), Drummond, então um provinciano e petulante poeta de 22 anos, distinguia ser brasileiro de ser nacionalista:

estou convencido que a questão da literatura no Brasil é uma questão de coragem intelectual. Ou por outra: é preciso convencer-se a gente de que é brasileiro! E ser brasileiro é uma coisa única no mundo; é de uma originalidade delirante. Não confundir com nacionalismo ${ }^{15}$.

Ou seja, embora estivesse convencido de que era necessário se assumir como brasileiro -

\footnotetext{
${ }^{14}$ Lélia Coelho (org.), op. cit., p. 180.

${ }^{15}$ Id., Ibid., p. 40.
} 
o que era menos óbvio do que parece, se lembrarmos a afetação e a artificialidade de boa parte da nossa vida literária do começo do século -, nosso Autor ainda tinha dúvidas sobre como e se valia mesmo a pena sê-lo não só porque achava "lastimável essa história de nascer entre paisagens incultas e sob céus pouco civilizados"16, como também porque tomava o nacionalismo no sentido então corrente do termo, isto é, como sinônimo de ufanismo e de patriotismo ("entendo por nacionalismo: ter princípios; fazer estatutos sobre o amor da pátria, etc." ${ }^{17}$ ) - daí dizer coisas como "cheirando a nacionalismo, acabouse: eu protesto". Drummond tomava o nacionalismo e o universalismo como opostos, o que o fazia recusar o primeiro e escolher o segundo, pensando optar assim por uma liberdade espiritual, por um cosmopolitismo que não estava inserido em lugar nenhum ("é que nasci em Minas, quando devera nascer (...) em Paris. O meio em que vivo me é estranho: sou um exilado"18). No fundo, porém, tratava-se de uma posição despaisada (como a chamou Mário) e descolada do país de origem, porque vexada com o atraso deste, que refratava as soluções das vanguardas com as quais sonhava o jovem poeta. Tudo somado, tratava-se de um recurso para adentrar a modernidade a despeito do atraso do contexto local.

Combinando doses iguais de pedagogia e camaradagem em suas respostas, Mário diagnosticou um caso típico de moléstia de Nabuco $^{19}$ no destinatário e prescreveu o alargamento do conceito de nacionalismo: "nacionalismo quer simplesmente dizer: ser nacional. O que mais simplesmente ainda significa: Ser" ${ }^{20}$. Mário desfazia desse modo a oposição entre nacionalismo e universalismo, afirmando que o que existia era "mau nacionalismo" - justamente o que o poeta mineiro tinha na cabeça. Antecipando em quase um ano a argumentação de "Assim falou o papa do futurismo", Mário afirmava que ser nacional significava ser verdadeiramente, isto é, viver, relacionar-se com o passado, com a terra e com a família, - de onde, aliás, a exortação repetida a toda hora para que nosso Autor parasse de ler autores franceses e fosse viver. O autor do "Prefácio interessantíssimo" estava sugerindo, em outras palavras, que a identidade nacional

\footnotetext{
${ }^{16}$ Id., Ibid., p. 16.

${ }^{17}$ Id., Ibid., p. 79.

${ }^{18}$ Id., Ibid., p. 56.

${ }^{19}$ Mário definiria a moléstia de Nabuco em sua entrevista de 1925 como: "isso de vocês andarem sentindo saudade do cais do Sena em plena Quinta da Boa Vista e é isso de você falar dum jeito e escrever covardemente colocando o pronome carolinamichaelismente". Mário de Andrade, "Assim falou o papa do Futurismo (1925)", cit., p. 236.

${ }^{20}$ Lélia Coelho (org.), op. cit., p. 70.
} 
deveria desabrochar de forma natural à medida que nos relacionássemos com a realidade brasileira, o que era muito diferente da reles imitação de modelos recebidos do exterior os quais, no entanto, poderiam nos ajudar a encontrar a nossa própria identidade. Ou seja, desde que fôssemos naturalmente seríamos brasileiros, e não egípcios, gregos ou italianos. E, uma vez brasileiros e nacionais, poderíamos então ser universais, porque teríamos enfim criado um ideal, uma orientação só nossa, cuja originalidade viria se somar a de egípcios, gregos e italianos no concerto das nações e que seria a nossa contribuição à humanidade. Portanto, ao invés da oposição imaginada por Drummond, Mário propunha uma dialética entre nacionalismo e universalismo muito mais complexa e interessante.

O tratamento ministrado via correspondência deu resultado, e rápido, pois em janeiro de 1925 nosso Autor já declarava, como que curado: "sou hoje brasileiro confesso. E graças a você, meu caro!"21. E de fato, a despeito da tibieza, "Ta'i!" foi escrito no fim do mesmo ano e representa uma espécie de virada dentro da formação do seu Autor, pois contém questões que, além de revelarem a enorme influência de Mário, e por isso mesmo, inserem o artigo no olho do furacão do debate sobre o nacionalismo instituído pelos modernistas. A conversão de nosso Autor ao Modernismo e, com ressalvas, à causa nacionalista se explica porque, de um lado, ele atinou com o sentido de nacionalismo defendido por Mário, avesso à patriotada e que era muito diverso do que ele, Drummond, vinha contestando, e, de outro, porque estava então em plena temporada de formação, aberto ao diálogo e disposto a voltar atrás em suas convicções, como assumiria em março de 1925: "ninguém mais do que eu reconhece que estou numa fase de formação intelectual, de extrema sensibilidade às influências de fora"22. De sua parte, o autor de Paulicéia desvairada incentivou o poeta mineiro desde a primeira carta a procurar seu caminho e a conquistar sua autonomia, esquivando-se de se colocar em uma posição de autoridade e estimulando discussões ("responda, discuta, aceite ou não aceite, responda"23). Durante os primeiros anos da correspondência, Drummond se aproveitou da dinâmica sincera e à vontade imprimida por Mário para perguntar, desabafar, queixarse, pedir conselhos, concordar, discordar, xingar, elogiar, criticar, como se procurasse saber tudo o que ia na cabeça do amigo para a partir do diálogo empreender a busca por

\footnotetext{
${ }^{21}$ Id., Ibid., p. 88.

${ }^{22}$ Id., Ibid., p. 109.

${ }^{23}$ Id., Ibid., p. 52.
} 
uma posição própria, que não precisava ser uma síntese e que no mais das vezes conservava a tensão de origem. Essa dinâmica capta algo da essência do pensamento poético de Drummond, cujo desenvolvimento ocorre em geral pelo embate e pela confrontação $^{24}$. É o que acontece, por exemplo, em diversos poemas de Alguma poesia e em "Ta'i!", onde existe um movimento duplo de aproximação e afastamento das formulações do autor de Paulicéia desvairada, cuja ascendência foi de qualquer forma decisiva $^{25}$, de outro.

O que mais chama a atenção no artigo de 1925, contudo, é a mistura de superficialidade inconsequente e de ânimo engajado na construção de uma tradição brasileira. Afinal, desde a Independência, o anseio de criar uma tradição esteve ligado com a construção de uma identidade para o país e, por isso, pressupunha um "horizonte político de luta, de transformação e de difusão das Luzes como índice da integração interna"26. Ora, "Ta'i!" desdenha por completo essa trajetória, apostando na convergência pacífica entre passadistas e evolucionistas, erudito e popular, vanguarda europeia e língua brasileira em torno de uma tradição nacional. Ou seja, sem desfazê-la completamente - o que dava ao artigo o seu aspecto polêmico -, a polarização entre posições antagônicas era atenuada pelo artigo. Porém, a acomodação precária resultante dessa atenuação era (e pretendia ser) improvável e pouco plausível, porque enunciada em um tom inconsequente e engraçado. Na verdade, o objetivo da perspectiva surpreendente configurada em "Ta'i!" era menos avançar uma proposta exequível em torno da construção de uma tradição autêntica e mais redimensionar a questão nacional, abordando-a de um ângulo inesperado

\footnotetext{
${ }^{24}$ Aliás, como o próprio Mário: "Mário de Andrade era o que chamaríamos hoje, inspirando-nos ainda uma vez em Bakhtine, uma "personalidade dialógica" por excelência. O curioso é que ele mesmo já tivesse visto isso antes de 1927, isto é, antes da divulgação no Ocidente dos conceitos do crítico russo. Àquela altura, discutindo por carta com Alceu Amoroso Lima as características de sua obra (dele, Mário de Andrade), chamava a atenção para o "sentimento trágico da vida" que ela manifestava, esclarecendo que entendia por tragédia "a dialogação do ser humano (no sentido mais completo) com o que não é ele, com o não-eu". A seu ver, um dos traços fundamentais de sua personalidade literária era, justamente, esse "diálogo interior consigo mesmo", que estava presente em toda a Paulicéia Desvairada, em grande parte de Losango Cáqui, em Amar, Verbo Intransitivo, em alguns contos de Primeiro Andar e em todo o Clã do Jabuti, sobretudo no poema "Carnaval Carioca"". Cf. Gilda de Mello e Souza, "O Banquete". In: _, Exercícios de Leitura. São Paulo: Livraria Duas Cidades, 1980, pp. 37-38.

${ }^{25}$ Sobre a influência de Mário sobre Drummond, dirá Gledson: "foi relativamente curta na sua fase mais intensa, mas, ao contrário da influência de Álvaro Moreyra, por exemplo, ela deu espaço para Drummond desenvolver seu próprio estilo e atitude, de maneira que o rompimento foi indolor e gradual, e mesmo talvez, até certo ponto inconsciente. Foi tanto estilística quanto temática (no sentido mais amplo da palavra), mas no seu aspecto estilístico foi menos duradoura. O que permaneceu foi um encontro com as aspirações e os ideais de Mário, como eles aparecem ao longo de toda a sua obra, mas que tiveram sua expressão mais intensa e pessoal no seu livro de poesia mais famoso, Paulicéia desvairada". John Gledson, Influências e impasses: Drummond e alguns contemporâneos. São Paulo: Companhia das Letras, 2003, p. 70.

${ }^{26}$ Iumna Maria Simon, "Condenados à tradição", in: Piauí, no 61, outubro 2011, p. 86.
} 
e anticonvencional. O artigo buscava, desse modo, deslocar a questão nacional do enquadramento tradicionalista e patrioteiro que predominou até o Modernismo e que impedia que a experiência local se constituísse como problema intelectual e estético ${ }^{27}$. É por isso que, embora irreal, sua proposta não era naquele momento descabida e, pelo contrário, tinha valor estratégico, pois ao investir contra o tradicionalismo reacionário que se apossara do conceito de nacionalismo, ele fazia coro aos demais modernistas e, em particular, a Mário e a Oswald.

Quanto à convergência imaginada entre os contrários, a própria conclusão de "Ta'i!" se encarregava de pô-la em xeque:

Por tudo isso é que eu protesto. Posso ficar sozinho mas protesto. Tradição brasileira é bobagem. Nas Feuilles de température de Paulo Morand encontro este versozinho:

Pretez votre concours à une ouvre de charité:

le monde est à recommencer.

O qual, traduzido pro brasileiro, diz isto:

Venham todos ajudar uma obra de coração:

o Brasil está por começar ${ }^{28}$.

Ao cogitar o protesto solitário ("posso ficar sozinho mas protesto"), nosso Autor punha em dúvida o empenho coletivo que ele próprio vinha conclamando, como se hesitasse diante do projeto difícil de ser levado a cabo e que poderia, talvez, implicar algum compromisso ou obstáculo à sua autonomia. Na verdade, a semelhança existente entre o final do artigo e de uma carta de dezembro de 1924 a Mário de Andrade ("cheirando a nacionalismo, acabou-se: eu protesto" ${ }^{29}$ ) testemunha a persistência do individualismo do Autor, que se acatara sugestões e repensara convicções nesse quase um ano de correspondência, não lograra superar o próprio individualismo. Essa tensão entre a autonomia pessoal e o empenho coletivo pode ser interpretada no sentido de um individualismo exacerbado, receoso talvez de uma participação à maneira por exemplo da proposta por Mário de Andrade, que sobretudo a partir de 1925 mergulharia nos

${ }^{27}$ Cf. Antonio Candido, "Uma palavra instável". In ,Vários Escritos. Rio de Janeiro, Ouro sobre Azul, 2012, pp. 217-227.

${ }^{28}$ Carlos Drummond de Andrade, “Ta'i!", cit., p. 260.

${ }^{29}$ Lélia Coelho (org.), op. cit., p. 79. 
estudos sobre Folclore e Antropologia em busca de materiais anônimos e populares para a criação artística, e cujo resultado mais notável seria Macunaíma ${ }^{30}$. Por outro lado, é de pensar se o gesto de Drummond no fundo não seria também uma atitude de classe, ciosa da sua própria inserção cultural e dos privilégios reservados a ela. Pelo sim pelo não, ao mobilizar as tradições populares como um recurso disponível entre outros à sua posição e sem um desdobramento que justificasse ou problematizasse essa apropriação - com o que se distingue por exemplo de Macunaíma -, o artigo de 1925 revela o caráter de classe desse individualismo e os limites afinal estreitos do seu radicalismo. Afinal, a valorização da cultura popular, alardeada ao longo do texto, vinha acompanhada desde dentro de um ranço conservador entranhado - dubiedade que o aproxima tanto da polêmica modernista esclarecida quanto das concepções retrógradas do seu tempo. Não obstante, e variando o foco, é inegável que o artigo comprova a distância existente entre as posições provincianas do jovem poeta que começara a se corresponder com Mário em 1924 e as confusamente nacionalistas do Autor de "Ta'i!", ainda bastante influenciado pelo amigo paulista, mas já à procura de um programa para chamar de seu e no qual se complementassem nacionalismo e individualismo - tal programa, Drummond o formularia poeticamente em "Explicação", do ano seguinte, como veremos.

Em "Ta'i!", conjugam-se as influências modernistas, sobretudo através do diálogo com sua figura de proa, Mário de Andrade, o individualismo do Autor e o caldo de cultura tacanho da época e, mais especificamente, o da provinciana Belo Horizonte do começo do século - combinação que está no centro de praticamente toda sua produção do período. Mas o resultado no artigo de 1925 é confuso, porque esses elementos brigam entre si e procuram sobrepor-se uns aos outros, tensionando o conjunto. Longe de ser um problema - até porque o artigo constituía uma espécie de tirocínio, publicado ademais em um meio consumível como o jornal -, essa mistura incongruente era explorada por Drummond, que experimentava, como em um balão de ensaio, a combinação inesperada entre ousadias formais e perspectivas contraditórias entre si. Tratava-se, assim, de testar o rendimento literário e o potencial polêmico (os dois são indissociáveis em "Ta'i!") da mistura de procedimentos e questões modernistas e modernas com concepções tradicionais e

\footnotetext{
${ }^{30}$ É a posição por exemplo de Alcides Villaça, para quem: "encampar os inquietos compromissos de Mário de Andrade com a cultura nacional teria para o gauche o sentido de uma sublimação indesejável, de um 'sequestro' inadmissível". Alcides Villaça, Passos de Drummond. São Paulo: Cosac Naify, 2006, p. 15. Para um roteiro do percurso intelectual de Mário, Cf. Telê Porto Ancona Lopez, Mário de Andrade: ramais e caminhos. São Paulo: Livraria Duas Cidades, 1927.
} 
acanhadas. E, justamente por tentar internalizá-las, o artigo tinha sua coerência esfacelada. Porém, o seu andamento - cujo princípio formal é o borboleteio entre os antagonismos - não adere ao que há de problemático nessa complicada relação de forças que se repelem e assume, ao invés, um ar de brincadeira inconsequente que despressuriza os antagonismos acumulados, como uma grande válvula de escape. E, nessa operação de recorrer ao humor para desarmar ambiguidades e tensões que, no limite, diziam respeito à posição incerta do Brasil diante do universo moderno, do qual fazíamos e não fazíamos parte, nosso Autor convergia com os seus pares e com a alegria comumente associada com o primeiro tempo do nosso Modernismo, basta lembrar, por exemplo, o otimismo de Mário e de Oswald em suas publicações do mesmo ano. Vista com recuo histórico, essa alegria pode parecer mais ingênua do que efetivamente era, pois constituía na verdade uma espécie de consciência possível e, para aquele momento, até avançada dos impasses do país.

Essa operação é muito semelhante a que Drummond vinha ensaiando em seus versos do mesmo período. Na produção do poeta mineiro da época, há uma aproximação evidente entre prosa e verso, tanto assim que, das quatro colaborações para o "Mês modernista", duas foram em prosa e duas foram em versos. A sua primeira colaboração foi o artigo "O homem do pau brasil", em que analisava o "Manifesto Pau Brasil" e o livro de poemas recém-publicado por Oswald de Andrade. Tratava-se de uma crítica à blague e, sobretudo, ao descuido artístico de Oswald em seus poemas, que resvalavam, segundo Drummond, na caricatura. Escrito em um tom pernóstico que se distingue radicalmente do livro, o artigo pode ser interpretado dentro do processo de formação do Autor como uma recusa teórica ao primitivismo de Pau Brasil, que não obstante o influenciou por causa seja do despojamento da sua linguagem, seja dos seus cromos de província $^{31}$. A sua segunda colaboração foram os poemas "Nota social" e "Sabará", ambos republicados em Alguma poesia. Já a sua quarta colaboração foi o conjunto de poemas "Bucólica no caminho do Pontal", "Política" e "Itabira", os quais, com exceção do primeiro, também foram incluídos no seu livro de estreia. Entre as quatro colaborações, há uma coerência rigorosa. De um lado, a variação de registros deve ser interpretada como um sinal de que o poeta mineiro estava naquele momento experimentando as potencialidades da prosa, do verso livre e, sobretudo, da combinação

\footnotetext{
${ }^{31}$ Mais adiante analisaremos como Drummond assimilou e reinventou esses cromos de província em sua representação da Belo Horizonte do começo do século.
} 
dos dois. No caso de "Ta'i!", essa experimentação assume a forma do confronto sistemático às convenções gramaticais. Mas não é só nele que há experimentação. Apesar das diferenças, em todas as suas colaborações o poeta mineiro parece, de uma forma ou outra, testar procedimentos e dicções. Essa experimentação é, por sinal, uma das constantes da produção de Drummond do período e é retomada em poemas posteriores, notadamente em "O sobrevivente" e em "Outubro 1930", também publicados em Alguma poesia. De outro lado, as quatro colaborações ao "Mês modernista" constituem um esforço explícito de ingressar no Modernismo. A constelação composta pela crítica a um livro-chave do movimento, pela criação artística vincada pelas conquistas modernistas e pela tomada de posição na discussão sobre a tradição constitui uma espécie de esforço para se filiar ao Modernismo por meio de caminhos diversos, mas complementares.

O modelo de prosa de "Ta’i!" é a do ensaísmo praticado por Mário e por Oswald, cujos escritos o influenciaram bastante, como procuramos sugerir. Trocando em miúdos, o artigo se inspirava, de um lado, na concepção exposta em "Assim falou o papa do Futurismo" e, de outro, no ar de piada dos poemas de Pau Brasil, e os combinava livremente, criando uma estrutura pessoal. “Ta'i!" se assemelha muito à prosa de ensaio dos dois modernistas porque, como eles, se valia da circunlocução, isto é, "em lugar de adotar o termo técnico (antilocalista por natureza) consagrado na filosofia, na historiografia, na sociologia etc., o ensaísta diz mais ou menos a mesma coisa usando outras palavras, tomadas ao cotidiano familiar"32. E, como notou Roberto Schwarz:

Esta preferência exprime o sentimento de que a conceituação estabelecida na teoria europeia não é ajustada à realidade local. Por outro lado, em consequência mesmo de seu ganho em realismo e propriedade, a prosa de ensaio destes autores perde em conexões teóricas, em sistematicidade e em rigor expositivo. O resultado é algo como uma esperteza, a que não falta a nota humorística: não vamos embarcar numa terminologia que não nos diz respeito; fiquemos por aqui, dento desta realidade um tanto diferente e tão nossa - e que por isso mesmo está a salvo (ou idilicamente abaixo?) da cena contemporânea ${ }^{33}$.

\footnotetext{
${ }^{32}$ Roberto Schwarz, "Crise e literatura". In: ,Que horas são?. São Paulo: Companhia das Letras, 1987, p. 162.

${ }^{33}$ Id., ibid, pp. 162-163.
} 
A ambivalência contida na prática da circunlocução, que representa um ganho em clareza e concretude ao preço de uma perda em sistematicidade e rigor, está no centro mesmo de “Ta'i!", porque, se é o que lhe dá o aspecto polêmico e, em certo sentido, o próprio interesse, também é o que mina a exposição, tornando-a confusa. O que não chega a ser um problema para o artigo, porquanto ele próprio não se pretende sério e abraça, ao invés, o piadismo deslavado. $\mathrm{Na}$ verdade, ao abrir mão da seriedade e, principalmente, da sistematicidade, o artigo se coloca em uma posição ainda mais ambígua do que a "meia seriedade" 34 dos ensaios de Mário e Oswald e, em alguns momentos, chega a parecer um pastiche deles. De fato, a identificação entre humor e polêmica resulta em uma confusão tamanha que dificulta determinar o alvo da zombaria.

Não obstante, “Ta'i!” ocupa uma posição estratégica dentro da obra de Drummond e, mais especificamente, da sua produção da década de 20 , porque constitui a primeira tentativa de formular questões importantes que o acompanhariam até mais ou menos o começo da década de 30, como procuramos sugerir no percurso concebido por este trabalho. $\mathrm{O}$ artigo também é curioso porque à sua maneira relativiza a "divisão do trabalho literário" 35 identificada por Antonio Candido a propósito da obra de Drummond. De acordo com Candido, o verso e a prosa ocupariam papéis distintos nela porque, a despeito de se tratar dos mesmos assuntos e da mesma sensibilidade, no primeiro essas seriam mais tensionadas pela exploração concentrada das possibilidades de cada termo, ao passo que na segunda elas seriam distendidas por um uso mais transitivo e folgado das palavras e construções. Ora, “Ta’i!” embaralha essa divisão porque despreza completamente a transitividade associada à prosa, apostando em um uso provocativo e gramaticalmente incorreto. Nem por isso as questões condensadas nele são menores ou desimportantes. Pelo contrário, e a despeito do ar de brincadeira que o caracteriza, o artigo lida com questões cabeludíssimas que ocupariam nosso Autor por toda a segunda metade da década de 20 e ainda tem o mérito de ser umas das primeiras, senão a primeira ocasião, em que Drummond lhes dava forma própria e as enfrentava.

\footnotetext{
${ }^{34}$ Id., ibid., p. 163.

${ }^{35}$ Antonio Candido, "Drummond prosador". In: 22 . Recortes. Rio de Janeiro: Ouro sobre Azul, 2004, p.
} 


\section{CAPÍTULO 2}

\section{EU NÃO DISSE AO SENHOR QUE NÃO SOU SENÃO POETA? (1926)}

A primeira referência a "Explicação" data - salvo engano - de 1926 e se encontra em carta de Mário de Andrade a Drummond. Em carta de agosto daquele ano, Mário comentava um por um e verso a verso os poemas que o amigo mineiro pretendia então reunir sob o título de Minha terra tem palmeiras. O projeto de livro logo foi abandonado, mas "Explicação" não, e depois foi incluído com pequenas modificações em Alguma poesia. O poema - é o meu palpite - representou um passo importante dentro da sua produção no sentido de definir um programa poético mais ou menos consistente que nosso Autor desdobrou desde sua redação por volta de 1926 até digamos 1931, ano da primeira publicação de "Outubro 1930", onde esse programa começou talvez pela primeira vez a se revelar problemático. Por sua vez, a opinião de Mário certamente teve papel importante, se não decisivo, no destino de "Explicação", tamanha era sua ascendência sobre o poeta mineiro, particularmente naquele momento. Corria o ano de 1926, e o remetente da rua Lopes Chaves dizia a propósito do poema:

peso pesado. Mesma coisa que "Eu protesto" porém sem besteiras e muito mais melhor. Forte mesmo. Eu botaria isto no começo do livro que nem Prefácio. E datava o poema, assim como datava as partes do livro. Convém datar. Tem uns versos meio tontos o $4^{\circ}$ e o $5^{\circ}$ por exemplo que são "Folha de taioba, pouco importa! tudo serve./ Pra louvar a Deus como pra aliviar o peito". "Falam uma língua" prefiro "falam língua"; "mete a sua língua" prefiro "mete a língua". ${ }^{36}$

Ou seja, reconhecendo sua vocação programática, Mário sugeria que o poema ocupasse uma posição estratégica dentro do conjunto. É claro que a ideia era fazer de "Explicação" algo semelhante ao "Prefácio interessantíssimo" ou a "A escrava que não é Isaura", isto é, uma espécie de prefácio ou poética. Isso, em 1926. Porém, quando Alguma poesia finalmente saiu, quatro anos depois, "Explicação" aparecia entre os últimos poemas do livro (e apenas com a segunda das alterações sugeridas pelo amigo). O que terá levado Drummond a não acatar, ou melhor, a só acatar em parte a sugestão de Mário?

\footnotetext{
${ }^{36}$ Lélia Coelho (org.), Carlos \& Mário: correspondência entre Carlos Drummond de Andrade - inédita - $e$ Mário de Andrade: 1924-1945. Rio de Janeiro: Bem-Te-Vi, pp. 233-234.
} 


\section{EXPLICAÇÃO}

Meu verso é minha consolação.

Meu verso é minha cachaça. Todo mundo tem sua cachaça.

Para beber, copo de cristal, canequinha de folha de flandres,

folha de taioba, pouco importa: tudo serve.

Para louvar a Deus como para aliviar o peito, queixar o desprezo da morena, cantar minha vida e trabalhos é que faço meu verso. E meu verso me agrada. ${ }^{37}$

Se o objetivo fosse mesmo explicar, como o título sugere, talvez pudéssemos dizer que o começo do poema surpreende porque suas primeiras estrofes estabelecem identificações que mais confundem do que esclarecem o leitor. Logo no primeiro verso, o eu lírico verso define o seu verso como sua consolação. Ao invés de tornar mais inteligível o que é o seu verso, a definição o torna mais abstrato e pessoal, portanto mais difícil de precisar, o que vai em sentido oposto à ideia mais comum de explicação. Já no segundo, o eu lírico identifica o seu verso com algo muito mais concreto, o que possibilita uma socialização, já que como ele todo mundo tem sua cachaça. A identificação, primeiro, entre verso e consolação e, depois, entre verso e cachaça (e, logicamente, entre consolação e cachaça), possibilita um salto que, partindo do mais abstrato e íntimo - o que é ressaltado pela repetição do pronome possessivo -, atinge o mais geral e objetivo. Esse percurso contém algo do movimento do poema como um todo, onde o individual funciona como uma espécie de trampolim para atingir o geral, como veremos. No plano mais estritamente do conteúdo, a identificação inusitada entre consolação - um sentimento elevado - e cachaça - uma bebida popularíssima - promove um rompimento com hierarquias e convenções que permite ao verso do eu lírico transitar por diferentes assuntos e temas. Já no plano mais estritamente da forma, essa mescla se configura na convivência entre versos metrificados - como o primeiro, um decassílabo - e versos livres - como os demais da estrofe, que às vezes se aproximam da prosa e às vezes parecem aglutinar dois versos em um único -, e entre estrofes irregulares de diferentes tamanhos. Essa impressão de liberdade é intensificada pelas desdiferenciações estabelecidas nos dois últimos versos da primeira estrofe e nos dois primeiros da segunda. Sob a perspectiva da função de cada um, o eu lírico identifica coisas tão distintas quanto copo de cristal e

${ }^{37}$ Carlos Drummond de Andrade, Poesia 1930-62. Organização Júlio Guimarães Castañon. São Paulo: Cosac Naify: 2012, pp. 143-145. 
folha de flandres, louvar a Deus e queixar o desprezo da morena, - afinal uns servem para beber cachaça e outros para serem exprimidos pelo seu verso, respectivamente. Há uma viravolta curiosa aí, segundo a qual não é o verso do eu lírico que precisa se moldar de acordo com este ou aquele assunto, mas estes que são adaptáveis àquele, capaz ao que parece de tudo abarcar.

A desenvoltura com que o eu lírico transita entre os mais variados assuntos e formas talvez tenha impressionado Mário de Andrade. Mas o mais provável é que a reação animada de Mário se devesse principalmente à sua euforia naquele momento com os rumos do Modernismo - haja vista por exemplo a admiração que expressou em 1924 a respeito do título do projeto de livro do poeta mineiro, Minha terra tem palmeiras, que apenas quatro anos depois era por ele considerado manifestação típica do "brasileirismo de estandarte" 38 , então em voga, como detectaria em carta a Drummond. É provável que o juízo de Mário também estivesse ligado com o contraste de "Explicação" em relação aos demais poemas do projeto de livro, que foi uma tentativa do poeta mineiro de reunir sua produção em versos, mas cuja maior parte foi abandonada depois. Com efeito, comparado com as reminiscências penumbristas e com os canhestros ensaios modernistas que também compunham Minha terra tem palmeiras, "Explicação" sobressai porque nele Drummond elaborou - até onde sei - pela primeira vez uma resposta pessoal para os impasses que vinha enfrentando para forjar uma voz poética ao mesmo tempo moderna e nacional. Ou melhor, no poema se configura uma liga singular e de longo alcance entre nacionalismo e individualismo que representa uma espécie de solução de compromisso entre o desejo do Autor de se assumir brasileiro, incutido em particular por Mário de Andrade, e o seu próprio individualismo, do qual não abria mão. Como teremos oportunidade de ver, tratava-se de uma solução interessante dentro de seus limites e que abriu várias picadas poéticas, exploradas depois em outros poemas de Alguma poesia, como "Também já fui brasileiro", "Fuga" e "Europa, França e Bahia", com os quais "Explicação" se constela e que, aliás, ajudam a explicar sua importância dentro do conjunto do livro de 1930. Por sua vez, a maioridade precoce representada pelo poema (afinal fazia apenas um ano que nosso Autor se convertera ao Modernismo e, com

\footnotetext{
${ }^{38}$ Lélia Coelho (org.), op. cit., p. 321. Na mesma carta, Mário escreve: "[..] pois esse tal de brasileirismo está me fatigando um bocado, de tão repetido e aparente [...] Também publico o Macunaíma que já está feito e não quero mais saber de brasileirismo de estandarte [...] Confesso que quando me pus trabalhando pró-brasilidade complexa e integral (coisa que não se resume como tantos imaginaram no trabalho da linguagem) confesso que nunca supus a vitória tão fácil e o ritmo tão pegável. Pegou. Eu estava disposto a dedicar minha vida pro trabalho. Bastaram uns poucos anos".
} 
muitíssimas ressalvas, à causa nacionalista ${ }^{39}$ ) não deixa de espantar o leitor de hoje, ainda mais levando em consideração que foi escrito em um momento de acelerado descarte de posições não só por parte de Drummond, mas do Modernismo de modo geral. Como se sabe, a segunda metade da década de 20 ficou marcada justamente pelo acirramento no debate sobre o nacionalismo e, consequência desta, pela crescente animosidade dentro das hostes modernistas. Sinal dessa movimentação implacável, que reverberou na obra de Drummond, é a grande quantidade de poemas que ele escreveu nessa época e - talvez mais significativo - de poemas que descartou quando organizou a grande arrumação que foi antes de mais nada o seu primeiro livro.

Meu verso me agrada sempre...

Ele às vezes tem o ar sem-vergonha de quem vai dar uma cambalhota, mas não é para o público, é para mim mesmo essa cambalhota.

Eu bem me entendo.

Não sou alegre. Sou até muito triste.

A culpa é da sombra das bananeiras de meu país, esta sombra mole, preguiçosa.

Há dias em que ando na rua de olhos baixos para que ninguém desconfie, ninguém perceba que passei a noite inteira chorando.

Estou no cinema vendo fita de Hoot Gibson, de repente ouço a voz de uma viola... saio desanimado.

Ah, ser filho de fazendeiro!

À beira do São Francisco, do Paraíba ou de qualquer córrego vagabundo, é sempre a mesma sen-si-bi-li-da-de.

E a gente viajando na pátria sente saudade da pátria.

Aquela casa de nove andares comerciais

é muito interessante.

A casa colonial da fazenda também era..

No elevador penso na roça,

na roça penso no elevador.

A distância entre o primeiro e o último verso da terceira estrofe separa o eu lírico do seu país. O percurso que vai de um a outro é inusitado. $\mathrm{O}$ eu lírico principia insistindo no caráter pessoal do seu verso, que se destina a ele mesmo. A afirmação desconcertante - que não deixa de ser também uma provocação, pois desconsidera completamente o seu público - corresponde no plano formal à composição pessoalíssima dos versos, que

${ }^{39}$ Tentei reconstruir esse processo no capítulo anterior. 
também destoam dos modelos consagrados, por serem longos e encharcados de prosa. Quer dizer, na estrofe não se encontram recursos tradicionalmente associados com a poesia, como rimas e aliterações, e o seu vocabulário é composto basicamente por palavras banais, empregadas em sentido literal e não metafórico. A clareza das construções sintáticas e do léxico - a qual pode ser vinculada ao intuito pedagógico implícito desde o título - contrasta, no entanto, com a sucessão truncada dos versos, que formam um andamento surpreendente. Isso porque a estrofe se desdobra em um movimento repleto de conjunções negativas, através do qual o verso e o eu lírico vão se revelando pelo que não são. Isto é, a sequência dos versos se desenrola no sentido de negar e contradizer o anterior, criando um conjunto que se desenvolve pelo acúmulo de negações. Daí que palavras como "sem-vergonha" e "cambalhotas" sejam mobilizadas para caracterizar, não um eu lírico alegre, como seria de esperar, mas um que é "até muito triste”. Essas negações retorcem a estrutura da estrofe e tensionam a transitividade pressuposta pela explicação, aproximando-a de uma confissão melindrosa. O resultado é um desajuste entre registros diferentes e que tem o seu ápice no último verso da estrofe "a culpa é da sombra das bananeiras de meu país, esta sombra mole, preguiçosa" -, cujo teor mistura seriedade e brincadeira, ou ainda, ânsia de explicar e galhofa. Na verdade, "Explicação" embaralha programaticamente as duas noções, pois a cambalhota do verso do eu lírico consiste precisamente nesse movimento de conversão da alegria em tristeza, do concreto em abstrato, do particular em geral, e vice-versa. E é graças a essa pirueta que o eu lírico pode encontrar o seu país como o resultado do mergulho no seu mais profundo e recôndito modo de ser, o qual, ao invés de individualizá-lo, identifica-o ao Brasil e aos brasileiros. O país de origem se transforma, portanto, em um modo de ser e sentir que determina e explica o indivíduo - e é por isso que a explicação do indivíduo se converte também em explicação do país, e vice-versa. Em oposição ao "sentimento do mundo" das obras de Drummond da década de 40, em "Explicação" e em sua produção até Alguma poesia se configura essa espécie de sentimento do país, experimentado a partir de sensações e vivências, e não de ideias e abstrações, e que aliás é muito distinto do outro, como veremos mais à frente.

As sensações e vivências próprias do modo de ser brasileiro são caracterizadas na quarta estrofe. Nesta, a sensibilidade tumultuosa do eu lírico - que é triste mas parece alegre, que chora, sente desânimo e saudade, enfim que é e não é ao mesmo tempo revela-se um reflexo da realidade do país, onde os contrários também coexistiam. $\mathrm{O}$ 
vínculo entre eles se estabelece através da justaposição de elementos de procedências histórico-sociais diversas - fita de Hoot Gibson e viola, casa de nove andares comerciais e casa colonial da fazenda, elevador e roça - e da sua internalização pelo eu lírico. Pois, se eram dados concretos da realidade, esses elementos também faziam parte e moldavam a sensibilidade daquele, sugerindo uma curiosa homologia entre indivíduo e nação. A convivência desentrosada entre modernidade e atraso assume uma dimensão dupla: de um lado, é o produto do incipiente e inacabado processo de modernização brasileiro, em particular do vigente em Minas, onde se misturavam novidades modernas e resquícios do passado colonial, e, de outro, constitui a personalidade, o modo de ser e de sentir do eu lírico, que internaliza esses antagonismos sem mediação. As antinomias da realidade eram, desse modo, absorvidas pelo eu lírico, cuja subjetividade consequentemente se fragmentava. A estrofe arma uma espécie de isomorfia entre a dificuldade de individuação do eu lírico e o meio amorfo ${ }^{40}$. Em termos psicológicos, a solução elaborada talvez possa ser considerada pouco sofisticada e até esquemática, por causa da relação de espelhamento algo mecânica entre indivíduo e país, fruto por sua vez da ausência de mediação entre eles. Não obstante, trata-se de uma solução que aproxima o poema do campo das questões propriamente modernas, em especial a da cisão do indivíduo, que é um dado central da modernidade e um dos tópicos recorrentes da arte moderna, como se sabe. Mas é preciso destacar que o poema topa com a problemática moderna e universal através da imersão na peculiaridade do dado local, o qual dá concretude às suas soluções e impasses. E realmente, projetada sobre o pano de fundo da história nacional, a cisão do eu lírico se ressignifica porque no Brasil a passagem do campo para a cidade se deu sem ruptura e como uma espécie de prolongamento natural. Ou seja, diversamente do que o conflito encenado na estrofe faria imaginar, a convivência entre modernidade e atraso tinha seu lastro na realidade, que a relativizava. E, uma vez relativizado o que havia de contraditório nessa convivência, redefine-se por tabela a própria fragmentação do eu lírico, já que os conflitos armados por ele não existiam. A problemática universal e abstrata era, desse modo, encontrada por um caminho enviesado e ligado à formação social do país que a especificava. A solução configurada em "Explicação", portanto, como que ganha outro peso e passa a representar uma espécie de formalização de um curso

\footnotetext{
${ }^{40}$ A propósito da permeabilidade entre o eu lírico drummondiano e o meio em que está inserido, tento no capítulo seguinte discutir os poemas ambientados em Belo Horizonte, cidade cuja representação deu a nosso Autor a chance de investigar a peculiaridade e a viabilidade do Modernismo em Minas.
} 
histórico determinado, o que potencializa seu interesse.

A refração nacional também joga luz na figura do eu lírico. Pois o que este sentia como problemático, a realidade abrigava como complementaridade. No limite, é como se ele forçasse um conflito inexistente e - prova da sua inconsistência - que não por acaso seria desmanchado na estrofe seguinte, onde o foco passa por uma viravolta desnorteante, e o caráter de indeterminação dramática da quarta estrofe dá lugar à identificação afetiva. Em outras palavras, é a própria sequência de "Explicação" quem sugere que a propalada homologia entre eu lírico e realidade não passa de mais uma cambalhota, já que depois da quarta estrofe o tom dramático é abandonado. Ao ser posta em dúvida pelo desenvolvimento do poema, que se contradiz com suas próprias cambalhotas, a suposta identificação entre eles deixa entrever a parcialidade do eu lírico, que está em situação e que não é neutro. Ou por outra, com as inconsistências geradas por suas cambalhotas, o eu lírico adquire espessura e profundidade ficcional próprias, descolando-se do Autor e podendo ser confrontado pelo leitor ${ }^{41}$. Daí que a relação do leitor com "Explicação" deve ser crítica e desconfiada, e não passiva, o que aliás faz jus às insistentes provocações do eu lírico. A serem lidas dessa maneira, as incongruências apontadas tanto no plano da forma quanto no do conteúdo não são defeitos ou falhas estéticas, mas, ao invés, elementos de composição e, em última análise, princípio de construção do poema, que se transforma em uma sondagem aguda da subjetividade e que permite a leitura a contrapelo do discurso estapafúrdio do eu lírico. A densidade ficcional deste permite, inclusive, escavar mais. Com o descolamento entre eu lírico e país, a identidade psicológica e social do primeiro se deixa ver com mais clareza. O que surge é o filho de fazendeiro, que transita entre os dois polos, o rural e o urbano, e que usufrui de ambos sem pertencer propriamente a nenhum, flutuando por cima das tensões decorrentes dessa duplicidade. Nascia, desse modo, a persona do "fazendeiro do ar", que é também e sobretudo um tipo social. Presente em diversos momentos da produção poética posterior de Drummond, mas aparecendo pela primeira vez justamente em "Explicação" ${ }^{42}$, o fazendeiro do ar é, nas conhecidas palavras de Roberto Schwarz, o "homem que vem da propriedade rural para a cidade, onde recorda, analisa e critica, em prosa e verso, o contato com a terra, com a

\footnotetext{
${ }^{41}$ A inspiração aqui é o trabalho feito por Roberto Schwarz de desmascaramento do narrador machadiano, com o qual o eu lírico de "Explicação" apresenta semelhanças. Cf. Roberto Schwarz, Um mestre na periferia do capitalismo. São Paulo: Livraria Duas Cidades; Editora 34, 2012.

${ }^{42}$ De acordo com Vagner Camilo. Cf. do Autor, "A cartografia lírico-social de Sentimento do Mundo", in: Revista USP. São Paulo, março/maio, nº 53, 2002, p. 67.
} 
família, com a tradição e com o povo, que o latifúndio possibilitava"43. Assim definida, a figura do fazendeiro do ar tem o seu caráter de classe enfatizado, contrariando a ausência de diferenciação ao longo do poema e colocando-a em xeque. E é justamente por causa dessa omissão dos antagonismos de classe que o fazendeiro do ar tal como surge no poema se diferencia de suas ocorrências posteriores a partir de "Confissão do itabirano", de Sentimento do Mundo (1940), onde há uma dimensão de culpa social e autoironia ${ }^{44}$ que inexiste em "Explicação", cujo eu lírico tenta, pelo contrário, identificar-se com o país e com seus patrícios.

Por outro lado, se se trata, como nota Schwarz, de uma "figura tradicional da literatura brasileira deste século"45 - o que não deixa de ser um sinal da amplitude da experiência social correspondente -, o fazendeiro do ar também contém, sem prejuízo da sua objetividade ficcional em "Explicação", um aspecto autobiográfico sugestivo demais para ser desconsiderado. Como se sabe, Carlos Drummond de Andrade nasceu em outubro de 1902 no interior de Minas Gerais, em Itabira, filho de uma família tradicional da região, e se mudou para a capital do Estado no início de 1920. Menos do que a oposição entre campo e cidade, a mudança de Itabira para Belo Horizonte pode ser interpretada como a passagem de uma cidade interiorana e pequena, onde sua família era influente e conhecida, para outra bem maior, inaugurada em dezembro de 1897 e com pouco mais de cinquenta mil habitantes em 1920, em processo de crescimento e que se modernizava aos poucos, mas ainda bastante provinciana e caipira, sobretudo no que diz respeito à sua vida intelectual e cultural ${ }^{46}$. Em Belo Horizonte, Drummond cursou a faculdade de farmácia (que nunca exerceu) e começou a trabalhar nos jornais locais, primeiro no Jornal de Minas e depois no Diário de Minas, órgão oficial do Partido Republicano Mineiro, participando da rala vida mental mineira da época, que se concentrava em torno de redações, bares e livrarias. Em 1926, casado e precisando ganhar a vida ${ }^{47}$, Drummond

${ }^{43}$ Roberto Schwarz, "Cultura e política, 1964-1969", In: O pai de família e outros ensaios. Rio de Janeiro: Paz e Terra, 1978, p. 92. Para um comentário notável sobre a passagem do mundo rural para a cidade vivida liricamente pelo narrador de $O$ amanuense Belmiro, de Cyro dos Anjos, Cf. Roberto Schwarz, "Sobre $O$ amanuense Belmiro", in: id., ibid., pp. 11-20. Por sinal, existe um inequívoco ar de família entre Belmiro e Drummond, cujos poemas são textualmente citados no romance.

44 "O "sentimento do mundo" é também um sentimento de culpa, de onde uma certa tendência à autocrítica". José Guilherme Merquior, Verso universo em Drummond. Rio de Janeiro: José Olympio, 1976, p. 39.

${ }^{45}$ Roberto Schwarz, "Cultura e política, 1964-1969", cit., p. 93.

46 Para uma reconstrução do desenvolvimento da capital mineira, Cf. Paul Singer, Desenvolvimento econômico e evolução urbana. São Paulo: Editora Nacional, 1968, pp. 88-114.

${ }^{47}$ Em carta a Mário de primeiro de abril de 1926 dirá Drummond: "Até hoje não ganhei um vintém com a minha mão, a não ser aquele cobre da Noite e um outro menor ainda em Belo Horizonte. ATÉ HOJE VIVO 
arriscou uma volta à Itabira para tentar dar continuidade à linhagem rural e administrar a fazenda da família. A experiência, todavia, fracassou, e no mesmo ano ele voltou a Belo Horizonte, contratado pelo Diário de Minas, onde chegou a ser redator-chefe. O resumo, sumário embora, pretende indicar que a passagem de nosso Autor do interior para a capital se deu sem rupturas cortantes ou conflitos irreconciliáveis. Quer dizer, as idas e vindas entre Itabira e Belo Horizonte atestam que as origens rurais não eram incompatíveis com o presente urbano e, pelo contrário, emaranhavam-se nele. Enfim, resquícios do passado e novidades modernas se combinaram na experiência pessoal de Drummond, o que certamente contribuiu para que ele os visse em conjunto e os articulasse em seus poemas do período, cuja força também está relacionada com a recriação literária dessas ambivalências.

Quem me fez assim foi minha gente e minha terra e eu gosto bem de ter nascido com essa tara.

Para mim, de todas as burrices a maior é suspirar pela Europa.

A Europa é uma cidade muito velha onde só fazem caso de dinheiro e tem umas atrizes de pernas adjetivas que passam a perna na gente. O francês, o italiano, o judeu falam uma língua de farrapos. Aqui ao menos a gente sabe que tudo é uma canalha só, lê o seu jornal, mete a língua no governo, queixa-se da vida (a vida está tão cara) e no fim dá certo.

Se meu verso não deu certo, foi seu ouvido que entortou. Eu não disse ao senhor que não sou senão poeta?

Em um tom que oscila entre a afirmação e a provocação, o eu lírico assume as próprias origens, desfazendo o conflito configurado na estrofe anterior. De novo, o seu modo de ser é atribuído à sua terra e gente, só que desta vez ele o chama de "tara". Quer dizer, o seu modo de ser, que era determinado pelo país de origem, é reputado um defeito, uma perversão, mas - aí a surpresa - um defeito de que o eu lírico diz agora gostar bem, contrariando o que o poema vinha sugerindo. É claro, porém, que a noção de tara pressupõe a existência de um modelo, de uma norma em relação à qual ela se define como desvio. E de fato, na sequência descobrimos que a norma no caso era a Europa, pela qual alguns de seus compatriotas suspiravam (o que o eu lírico achava a maior das burrices, por motivos que expõe na sequência) e em confronto com a qual o modo de ser brasileiro

À CUSTA DE MEU PAI. Procure sentir o que há de doloroso nesta confissão dum homem de 23 anos, casado". Lélia Coelho (org.), Op. cit., p. 207. 
se constitui como tara. Note-se que, ao considerar uma burrice suspirar pela Europa, o eu lírico desqualifica ao mesmo tempo os seus compatriotas, que a idealizavam indevidamente, e a Europa, que não era nenhuma maravilha pela qual se pudesse suspirar. Em suma, trata-se de uma definição do Brasil pelo avesso, semelhante à dos parágrafos anteriores e que, como a deles, depende de uma negação. Essa maneira de definir é inusitada, porque a identidade surge como a diferença de algo que já existe, e não como alteridade, isto é, com uma identidade própria ${ }^{48}$. Definido dessa maneira, a identidade do Brasil é atrelada à da Europa e continua em última análise a depender dela. Assim, a burrice que era suspirar pela Europa é invertida apenas em parte em "Explicação", porque se se tratava de afirmar o Brasil como um modo de ser próprio, o poema recorre para tanto ao que lhe era diferente, com o que ressalta a ausência de uma identidade imanente do torrão natal. O país de origem até saía valorizado dessa operação, pois ganhava positividade, mas nem tanto, já que sua identidade dependia de algo que lhe era estranho; ao passo que a Europa era achincalhada como uma "cidade muita velha onde só fazem caso de dinheiro", mas conservava sua precedência, pois o Brasil só se definia em oposição a ela. Logo, a comparação entre este e aquela revelava defeitos e vantagens de cada um, mais os defeitos do que as vantagens. Algo semelhante, por conseguinte, à convivência na estrofe anterior entre as origens rurais e a modernidade, as quais se relativizavam reciprocamente.

O resultado na quinta estrofe também é relativo: "aqui ao menos a gente sabe que é tudo uma canalha só". A disposição peculiar das partes e, sobretudo, a passagem da locução "ao menos" para o começo da oração destacam a modéstia da vantagem assinalada. Por um lado, é preciso reconhecer o que havia de audacioso e provocativo no simples ato de nos comparar com quem nos servia de modelo, dado o contexto tacanho e ainda dominado pela ideologia colonialista em que foi escrito "Explicação". Ao medir com o mesmo metro o seu país e a Europa, o poema o jogava no presente do universo, e as singularidades nacionais podiam ser confrontadas com as das outras nações, transformando-se em vantagens ou defeitos relativos. Com isso, o Brasil adentrava a modernidade, o que era um dos cavalos de batalha da produção modernista da década de 20, como procuramos sugerir no capítulo anterior ao comentar os escritos de Mário e de

\footnotetext{
${ }^{48}$ Sobre a lógica das similitudes, Cf. Michel Foucault, As palavras e as coisas. São Paulo: Martins Fontes, 1997.
} 
Oswald de Andrade do mesmo período, com os quais "Explicação" nesse sentido afinava. Por outro lado, porém, é impossível hoje ignorar o que havia de irreal nessa comparação. Embora não se tratasse propriamente de ufanismo - já que as vantagens identificadas só as eram de modo precário -, a proposta contida no poema é problemática por uma série de motivos. Entre eles, as generalizações absurdas, as imagens grosseiras da Europa e dos brasileiros etc. etc. Todos esses motivos derivam da identificação da nação com um modo de ser. Quer dizer, o nacionalismo elaborado no poema consiste, como os de Mário e Oswald, em um certo caráter nacional. Entretanto, diferentemente do deles, trata-se de um caráter que era ao mesmo tempo nacional e individual. Isto é, o modo de ser e de sentir do eu lírico (e que era o de todos os brasileiros) é tomado como atributo do país, de sorte que se arma uma comunhão tal entre eles que um vale o outro. E justamente, a sobreposição entre eles como que barra a possibilidade de um distanciamento crítico, deixando margem apenas para as críticas ao nível imediato e individual ("burrice", "canalha" etc.).

Essa falta de distanciamento era um dos efeitos colaterais do esforço de Drummond para se identificar com o Brasil e aderir ao nacionalismo. Seguindo os conselhos dados por Mário de Andrade nas cartas trocadas entre 1924 e 1925 - que procuramos resumir no capítulo anterior -, mas interpretando-os e adaptando-os ao seu próprio individualismo, nosso Autor procurava viver o Brasil naturalmente, sem abstrações ou ideias genéricas. De modo mais específico, tratava-se de modular a ideia profundamente negativa e distanciada do país concebida pelo jovem mineiro que não começara a se corresponder com Mário com uma espécie de coisa sentida e vivida pelo poeta recém-convertido ao Modernismo ${ }^{49}$. Assim, o universalismo abstrato do primeiro, que queria se diferenciar do meio atrasado e inculto, dava lugar ao nacionalismo terra-aterra do segundo, que queria a todo custo se identificar com o país de origem ${ }^{50}$.

\footnotetext{
${ }^{49}$ Para John Gledson, o Brasil é representado em Alguma poesia com uma "complexidade de ideia criticada e coisa sentida", o que seria, inclusive, uma das explicações para a intensidade dos poemas da coletânea. Cf. John Gledson, Poesia e poética em Carlos Drummond de Andrade. São Paulo: Livraria Duas Cidades, 1981, p. 93. A meu ver, pelo contrário, há uma certa passagem do país pensado como ideia para o país experimentado como coisa, passagem que está relacionada com a conversão de Drummond ao Modernismo e, com muitas ressalvas, ao nacionalismo. O Brasil como ideia criticada era uma concepção do jovem Drummond que queria se distinguir do país; ao passo que o Brasil sentido como coisa foi como que o resultado da conversão de Drummond ao Modernismo e orientada por Mário de Andrade.

50 Discutindo a relação de Drummond com o nacionalismo, Ivan Marques afirma que "ao rejeitar o nacionalismo, Drummond revela a consciência de que "o Brasil é uma ideia falsa (ou sujeita a falsificações)". Ivan Marques, Cenas de um modernismo de província: Drummond e outros rapazes de Belo Horizonte. São Paulo: Editora 34, 2011, p. 97. Por sua vez, a formulação citada é de John Gledson. Cf. John Gledson, Poesia e poética de Carlos Drummond de Andrade, op. Cit., p. 64. A meu ver, não se trata
} 
"Explicação" se insere, pois, no intenso diálogo travado por Drummond com Mário de Andrade naquele momento. Nesse sentido, o poema pode ser interpretado como um capítulo decisivo dentro do processo de conquista de autonomia do seu Autor em relação ao amigo paulista. Salvo melhor juízo, ele representa o primeiro aproveitamento verdadeiramente pessoal e de interesse das formulações marioandradianas, de que nosso Autor estava impregnado à época. Isso porque, além dos conselhos recebidos via correspondência, o poema também incorpora sugestões e processos poéticos do amigo, notadamente os configurados em "O poeta come amendoim", para exprimir uma posição original, muito diversa em particular do universalismo contido na parte final do "Noturno de Belo Horizonte". Os dois poemas de Mário foram escritos em 1924 e publicados no mesmo livro, Clã do Jabuti, três anos depois, em 1927, mas Drummond os conheceu antes da edição em livro. Apesar da coincidência de data, trata-se de poemas muito diversos, ou melhor, de poemas que, apresentando-se como muito diferentes, na realidade se complementam - o que explica o fato de terem sido escritos no mesmo ano e publicados no mesmo livro. Quer dizer, tanto "O poeta come amendoim" quanto o "Noturno de Belo Horizonte" fazem parte da mesma dialética imaginada por Mário entre o particular e o geral, e que envolvia o indivíduo, a nação e o universo. Ou por outra, a identificação entre o eu lírico e o país do primeiro correspondia em outro plano à identificação entre o país e a fraternidade universal do segundo.

Em "O poeta come amendoim" - aliás dedicado a Drummond, o que não deixa de ser uma pista da existência de afinidades -, deve ter interessado sobremaneira a este justamente a identificação nos últimos versos entre o eu lírico e o seu país:

[...] Brasil que eu sou porque é a minha expressão muito engraçada

Porque é o meu sentimento pachorrento

Porque é o meu jeito de ganhar dinheiro, de comer e de dormir. ${ }^{51}$

Mas não só. A confecção dos versos certamente também o influenciou. Pois, como em

propriamente de rejeição, mas de uma adesão cheia de ressalvas e que, inclusive, obrigou Drummond a elaborar um nacionalismo para uso particular, como tento argumentar. Por sua vez, a consciência de que a ideia do país era falsa é como que ilustrada em "Explicação", onde o Brasil é experimentado, não como uma abstração, mas como um modo de ser concreto.

${ }^{51}$ Mário de Andrade, Poesias completas. Edição crítica de Diléia Zanotto Manfio, Belo Horizonte; São Paulo: Itatiaia; Editora da Universidade de São Paulo, 1987, p. 109-110. 
"Explicação", os versos do poema de Mário são bastante longos, brancos e têm um cunho prosaico e explicativo, o que fica claro no trecho citado pela anáfora da conjunção explicativa "porque", que de resto reforça o paralelismo entre indivíduo e nação. E, também como no poema de Drummond, em "O poeta come amendoim" o teor explicativo, construído com orações subordinadas, convive com a galhofa, configurando uma explicação engraçada, além de inusitada. Por outro lado, as diferenças entre os dois poemas também são notáveis. No poema de Mário, a explicação se tinge de contornos míticos, pois retrocede aos tempos primevos para descrever a gênese da nação. A partir desse retorno às origens, o poema vai avançando temporalmente até desembocar no eu lírico, que se torna uma espécie de rebento da história nacional. Por sua vez, a malemolência e a sensualidade do andamento marcado por sibilantes e nasais recria o processo de que o eu lírico é o produto e que encarna ${ }^{52}$. Já em "Explicação", pelo contrário, o foco se mantém colado ao eu lírico e ao presente, o que se evidencia pela conjugação dos verbos no presente do indicativo. A fixidez do foco do poema e a maior proximidade em relação ao eu lírico permitem uma maior caracterização deste, que revela mais elementos autobiográficos (filho de fazendeiro, a especificação espacial dada pelo rio São Francisco) do que o de "O poeta come amendoim", com o que também se diferencia deste. Em resumo, ao invés de um fruto da história nacional, como no poema de Mário, o eu lírico de "Explicação" pertence ao seu país por causa de um vínculo imediato e sentimental que compartilha com este.

Já a relação de "Explicação" com o "Noturno de Belo Horizonte" é mais nuançada. Drummond foi atraído pelo sentimento da terra do poema. É o que sugerem suas palavras de carta de 24 de dezembro de 1924 a Mário:

ele [o "Noturno de Belo Horizonte"] me fez crer que você tem razão, por isso que suas ideias nacionalistas o conduziram de maneira lógica a um poema tão rico de expressão e intenção, em que o sentimento da terra se confunde com o mais puro e desinteressado lirismo. ${ }^{53}$

O comentário é significativo porque revela os critérios e parâmetros do leitor de poesia

\footnotetext{
52 Para uma leitura mais detida de "O poeta come amendoim" e da sua relação com a obra de Drummond, cf. Simone Rossineti Rufinoni, "Mário e Drummond: nacionalismo, alteridade, arte", in: Estudos Avançados (USP), v. 80, 2014, pp. 247-264 e Ivan Marques, "Modernismo de pés descalços: Mário de Andrade e a cultura caipira", in: Revista IEB. São Paulo, no 55, 2012, pp. 27-42.

${ }^{53}$ Lélia Coelho (org.), Op. Cit., p 80.
} 
que Drummond era naquele momento. Com efeito, a nosso Autor interessava então a combinação (ou a confusão, como efetivamente promoveria em seu poema) entre o sentimento da terra e o lirismo desinteressado. De um lado, tratava-se de valorizar a pesquisa da expressão nacional, que Mário empreendia em seu poema ${ }^{54}$ e que também era à sua maneira encampada em "Explicação", seja pelo uso de palavras e expressões de sabor bem brasileiro (passar a perna, meter a língua, fazer caso etc.), seja pela valorização do português falado no Brasil em detrimento da "língua de farrapos" falada na Europa. De outro lado, tratava-se de uma contraposição interna ao "Noturno de Belo Horizonte", isto é, tratava-se de contrapor o começo do poema - puro e desinteressado - com o final presumidamente, impuro e interessado. Mas, impuro e interessado por quê? Porque a partir do verso "Vem, gente, vem ver o noturno de Belo Horizonte" a organização do poema começa a ceder a impulsos discursivos que abalam o andamento do começo em favor da pregação do amor e da fraternidade, como se a sensibilidade poética fizesse uma curva retórica ascendente e se transformasse em uma declaração de intenções, para lembrar a formulação precisa de Leandro Pasini ${ }^{55}$. O resultado são versos como:

O amor não é uma paz

E é por amor que Deus nos deu a vida...

O amor não é uma paz, bem mais bonito que ela

Porque é um complemento!... ${ }^{56}$

Assim, mesmo tendo gostado "ampla, vastamente" do poema e o considerado "seguramente o maior esforço da poesia nacional", Drummond não deixava de ressaltar: "só não é poesia (pelo menos assim o creio) o trecho em que você prega o nacionalismo universalista, e que podia figurar num discurso de 15 ou 19 de novembro" ${ }^{15}$. Portanto, se foi peça central para convencer nosso Autor a se converter ao nacionalismo - visto que na época em que conheceu o poema ele ainda estava em dúvida se valia mesmo a pena se assumir como brasileiro -, o "Noturno de Belo Horizonte" também foi importante porque iluminou suas divergências em relação a Mário, obrigando-o a forjar um nacionalismo

\footnotetext{
${ }^{54}$ Manuel Bandeira era outro fã do "Noturno de Belo Horizonte", que lhe foi dedicado e sobre o qual disse em carta a Mário: "você descobriu o grande poema brasileiro. Todas essas coisas da terra que você diz tão amendoim-torradamente [...] eu sufocava de dizer. Não sabia como. Você achou como". Marco Antonio de Moraes (org.), Correspondência Mário de Andrade \& Manuel Bandeira. São Paulo: EDUSP; IEB, 2001, p. 195.

${ }^{55}$ Leandro Pasini, Apreensão do desconcerto: subjetividade e nação na poesia de Mário de Andrade. Tese de Doutorado, FFLCH-USP, 2011, p. 14.

${ }^{56}$ Mário de Andrade, Poesias completas, cit., p. 118.

${ }^{57}$ Lélia Coelho (org.), Op. Cit., p. 80.
} 
para uso particular que fosse distinto do universalismo do amigo. Em outras palavras, e como uma espécie de réplica em um diálogo latente, Drummond elaborou no poema um nacionalismo que, diferentemente do de Mário, era puro e desinteressado, ou seja, que não cedia a qualquer tipo de pregação e dentro do qual o seu individualismo não precisava ser renunciado, já que a um individualista convicto como ele era então (basta lembrar o enxame de marcadores de primeira pessoa em "Explicação") não podia agradar o ritual sacrificial configurado no final de "Noturno de Belo Horizonte" entre indivíduo e forma poética em prol de uma fraternidade brasileira e universal ${ }^{58}$. No nacionalismo gestado em "Explicação", pelo contrário, o indivíduo e o país se identificam e compõem uma unidade que nada deve à Europa ou ao resto do universo.

Pensando em outras afinidades, o sentimento do país configurado em "Explicação" lembra também o célebre "sentimento íntimo", de Machado de Assis. Em "Notícia da atual literatura brasileira - Instinto de nacionalidade", de 1873, Machado argumentava que

não há dúvida que uma literatura, sobretudo uma literatura nascente, deve principalmente alimentar-se dos assuntos que lhe oferece a sua região, mas não estabeleçamos doutrinas tão absolutas que a empobreçam. O que se deve exigir do escritor antes de tudo, é certo sentimento íntimo, que o torne homem do seu tempo e do seu país, ainda quando trate de assuntos remotos no tempo e no espaço. ${ }^{59}$

A pretexto de um balanço de época e pensando em seu próprio projeto literário, que vinha ruminando e que viria a lume alguns anos mais tarde (Memórias póstumas de Brás Cubas, seu primeiro romance da segunda fase, foi publicado em 1881), Machado divergia do gosto então em voga por "toques nacionais" e propunha um nacionalismo que fosse "íntimo, diverso e melhor do que se fora apenas superficial"60. Ele renunciava, desse modo, ao que havia de exterior e superficial nos escritos dos seus predecessores, como

\footnotetext{
58 Comentando a ressalva de Drummond ao "Noturno de Belo Horizonte", Pasini afirma que: "o que Drummond, estritamente poeta, não percebeu, é que justamente esse trecho é o ponto de chegada do apostolado nacionalista de Mário, é a manifestação em poesia do argumento: "acredite que um sacrifício é lindo"”. Leandro Pasini, op. cit., p. 194. A meu ver, não se trata nem de um ponto de vista estritamente poético, nem de não perceber as implicações do apostolado de Mário, mas, pelo contrário, de defender o caráter subjetivo do lirismo, o que de quebra legitimava sua própria poesia. Tratava-se, pois, de uma reação programática que condizia com o individualismo de Drummond, pouco disposto naquele momento a aderir a qualquer sacrifício do indivíduo.

${ }^{59}$ Machado de Assis, Obras completas. Rio de Janeiro: Editora Nova Aguilar, 1996, p. 879.

${ }^{60}$ Id., ibid.
} 
Joaquim Manuel de Macedo e José de Alencar, de cujas obras entretanto se embebeu meticulosamente com o intuito de aproveitar e aprofundar os modelos por eles criados ${ }^{61}$. Já em "Explicação" se tratava, ao invés, de se identificar com o dado local imediato e até com o pitoresco (se queixar do desprezo da morena, meter a língua no governo etc.), os quais eram alçados a traços do modo de ser dos brasileiros. O poema espelhava, nesse sentido, o desrecalque do dado local promovido sistematicamente pelo Modernismo, com o qual convergia. Porém, o aproveitamento dos princípios e das conquistas modernistas nada tinha de ingênuo ou mecânico no poema, e era, pelo contrário, bastante pessoal, porquanto a pesquisa da nacionalidade se articulava e confundia com uma investigação da subjetividade (e com a busca por um meio de expressão mais condizente com o Brasil), criando uma reversibilidade cheia de interesse. O país era experimentado, em resumo, como algo ao mesmo tempo interior e exterior, o que ia na contramão do que Machado defendia em seu artigo. Vale lembrar, aliás, que em "Ta'i!", artigo de 1925 e portanto muito próximo cronologicamente de "Explicação", Drummond não poupava críticas aos escritores do passado (a Machado de Assis entre eles) e à tradição literária brasileira, afirmando que esta - "graças a Deus" - não existia ${ }^{62}$. Mas é claro que em "Ta'i!" se tratava de uma posição programática (de resto, como o nacionalismo de "Explicação"), até porque a obra de nosso Autor se delineou, como estamos vendo, em diálogo estreito com outros autores, com Mário de Andrade, em particular, e com o Modernismo, em geral. Seja como for, ao se aproximar inesperadamente e talvez à sua própria revelia da expressão de Machado, "Explicação" entroncava em um debate de espectro mais largo (uma tradição?) que o Modernismo atualizou, mas que o ultrapassava e que estava relacionado à problemática da formação da nossa literatura e, de modo mais amplo, à formação da própria nação. Ou, para lembrar a valiosa interpretação de Antonio Candido, tanto "Notícia da atual literatura brasileira - Instinto de nacionalidade" quanto

${ }^{61}$ Formulação adaptada de Antonio Candido, "O método de Machado de Assis", in: Vários escritos, Rio de Janeiro: Ouro sobre Azul, 2011, pp. 74.

${ }^{62}$ Antes mesmo de "Ta'i!", Drummond já criticara Machado no primeiro número de $A$ Revista, afirmando: "o escritor mais fino do Brasil será o menos representativo de todos. Nossa alma em contínua efervescência não está em comunhão com a sua alma hipercivilizada". Apud Ivan Marques, Cenas de um modernismo de província: Drummond e outros rapazes de Belo Horizonte. São Paulo: Editora 34, 2011, p. 96. Sobre essa crítica, aliás, Ivan Marques dirá: "a crítica ao mestre com quem seria tantas vezes comparado (lascivo do nada que "resolves em mim tantos enigmas", dizem os versos de "A um bruxo, com amor", do livro $A$ vida passada a limpo) soa falsa e incoerente sobretudo por ignorar a semelhança entre a concepção do poeta sobre o nacionalismo e as ideias do famoso ensaio "Instinto de nacionalidade", que Machado publicou em 1873, defendendo o "sentimento íntimo" do país em detrimento da visão pitoresca." Id., ibid, p. 96. As semelhanças entre os dois decerto existem, mas para os propósitos deste trabalho se tentou, pelo contrário, enfatizar as diferenças. Assim, se no artigo de Machado se tratava de internalizar e aprofundar o dado local, em "Explicação" se tratava, inversamente, de ostentá-lo. 
"Explicação" fazem parte e constituem no limite intervenções opostas sobre a dialética do local e do universal que, segundo Candido, regeu a literatura brasileira desde o Arcadismo até mais ou menos $1945^{63}$. Desta perspectiva, as diferenças existentes entre eles também podem ser vistas em relação ao contexto muito diverso em que cada um se situa. Afinal, se o artigo de Machado se inseria em um momento em que a formação literária brasileira estava em vias de se completar (e justamente por suas mãos), mas não a sociedade, que conservava a escravidão, o poema de Drummond foi escrito mais de meio século depois, quando o sistema literário já havia se consolidado, porém a nação, impulsionada pelo nascente processo de industrialização, continuava em busca da sua identidade - busca que o poema erige como seu motivo.

"Explicação" se encerra com uma acusação seguida de uma pergunta: "se meu verso não deu certo foi seu ouvido que entortou./ Eu não disse ao senhor que não sou senão poeta?". A contraposição armada pelos pronomes possessivos "meu" e "seu" repõe o abismo construído ao longo do poema entre o verso do eu lírico e o leitor. Já o emprego de uma rima interna e toante (verso/certo) parece ter o fito de provocar o leitor. De fato, o ouvido torto a que o eu lírico se refere talvez fosse o ouvido sensível aos recursos sonoros tradicionais, como rimas e assonâncias, e treinado (ou deformado) pelo formalismo de boa parte da tradição poética anterior ao Modernismo e, sobretudo, pelo Parnasianismo, aos quais o poema se opunha dessa maneira. Com o uso inesperado da rima interna, o eu lírico dá mostras de conhecer os recursos comumente associados com a poesia, mas os exibe apenas para desdenhá-los, sugerindo que seu verso prescindia deles. Tratava-se, em suma, de inverter as convenções e de substituí-las por um critério de uso pessoal, que refletia a subjetividade como uma espécie de medida psicológica, como a chamou Mário de Andrade em "A poesia em 1930". No ensaio publicado no calor da hora, Mário estabelecia uma correspondência entre a personalidade do poeta mineiro e o ritmo dos poemas de Alguma poesia. De acordo com o autor de Macunaíma, a convivência de atributos que se contrariavam com ferocidade - a timidez, a sensibilidade e a inteligência - e que caracterizavam Drummond psicologicamente era reelaborada no âmbito estético pela riqueza rítmica muito grande do livro, cuja verdade (psicológica ${ }^{64}$ )

\footnotetext{
${ }^{63}$ Sobre o tema, Cf. Antonio Candido, Iniciação à literatura brasileira. Rio de Janeiro: Ouro sobre Azul, 2010 .

${ }^{64}$ Sobre o psicologismo de Mário, Cf. Roberto Schwarz, "A poética de Mário de Andrade", in: __, A sereia e o desconfiado: ensaios críticos. Rio de Janeiro: Paz e Terra, 1981, pp. 13-23.
} 
residia na representação construída com o "compromisso" entre o verso livre e a métrica $^{65}$. Com isso, Mário tentava captar a especificidade de Alguma poesia para lhe assinalar a originalidade dentro do panorama literário da época. A questão da originalidade tinha sua razão de ser, de um lado, porque o Modernismo ia numa fase de estabilização e de rotinização quando saiu "A poesia em 1930", que levava esse dado em consideração, e, de outro, porque Alguma poesia reunia poemas de quatro, cinco, até seis anos anteriores à sua publicação - intervalo, como estamos sugerindo, repleto de viravoltas dentro da história do Modernismo, em geral, e do processo de formação de Drummond, em particular. Mário pretendia no ensaio, enfim, interrogar como o livro do poeta mineiro refratava as conquistas modernistas, se se valia delas com discernimento ou se era, pelo contrário, atropelado por elas. Mas o fato é que, mesmo usando processos e assuntos batidos quando da sua edição, Alguma poesia constituía, na opinião de Mário, um "documento precioso de psicologia"66 graças à reinvenção literária da subjetividade retorcida do Autor e cujo aspecto formal mais saliente para tanto era justamente o ritmo. Ou seja, o emprego de recursos tipicamente modernistas, em especial o verso livre, era disciplinado pela presença de uma "subjetividade tirânica" 67 que investigava a si e ao meio que lhe era coextensivo nos poemas do livro.

Essa subjetividade hipertrofiada se exprime com toda a força na pergunta final do poema. "Eu não disse ao senhor que não sou senão poeta?". O verso dodecassílabo e martelado por monossílabos se dirige diretamente ao público de ouvido torto e passadista, confrontando-o. Arrogando-se uma autoridade inusitada, o eu lírico se põe em uma posição de superioridade em relação ao leitor para reiterar que é, sim, poeta e que seu verso está, sim, certo. É claro que tamanha assimetria mina a possibilidade de diálogo entre eles, o que também fica claro pelo desprezo mal disfarçado pelo vago pronome de tratamento "senhor". Entretanto, se se destina a ironizar o leitor, a pergunta final também acaba incidindo sobre a própria eficácia da explicação que a antecedeu, abalando o poema em sua raiz. Quer dizer, a interrogação pode ser lida como uma admissão tortuosa de que o esclarecimento prometido desde o título fracassara, ou pelo menos, de que era

\footnotetext{
${ }^{65}$ Mário de Andrade, "A poesia em 1930", in: , Aspectos da literatura brasileira. Belo Horizonte: Itatiaia, p. 33. ${ }^{66}$ Id., Ibid., p. 34.

67 A expressão é de Antonio Candido, como se sabe. Cf. "Inquietudes na poesia de Drummond", in: , Vários escritos, op. cit., p. 68. A expressão de Candido retoma a argumentação de Mário, cujo ensaio aprofunda.
} 
questionável. Nesse sentido, o tom agressivo do fim seria uma espécie de contrapartida da tibieza do resultado enquanto uma tentativa de explicar e tentaria compensar a falta de nexo do todo com a afronta ao seu leitor. Longe de concluir ou sintetizar qualquer coisa, portanto, o verso final reabre problematicamente as questões condensadas ao longo do poema e, em particular, a que diz respeito à tensão entre o intuito explicativo e o resultado confuso. Mas é claro que essa tensão não era acidental, tanto assim que quando resolveu publicar "Explicação" em livro, Drummond o pôs entre os últimos poemas de Alguma poesia, contrariando o conselho dado por Mário em 1926, como se quisesse esconder uma das chaves do livro. Na verdade, o eu lírico do poema confunde programaticamente seu público através de suas cambalhotas, que estruturam atabalhoadamente o poema. Com essas piruetas, o eu lírico despista o leitor e ainda pode acusá-lo de não o compreender, nem a ele, nem ao seu verso. Por esse meio, tratava-se de afirmar o seu próprio modo de ser e, indiretamente, o do país de origem, através, não da adequação a rótulos convencionais, mas da confrontação desses rótulos. A identidade individual e nacional se afirmava, assim, como o resultado do embate entre normas e padrões contrários, que lhe constrangiam por todos os lados. Por isso mesmo, o resultado final é truncado, o que explica também o tom de blefe da pergunta final, que desafia normas e padrões. Em "Explicação", por conseguinte, se constituiu pela primeira vez e em solidariedade a identidade pessoal e a nacional, podendo ser lido nessa medida como uma espécie de certidão do Poeta - agora, sim, modernista - e de seu país - meio moderno meio atraso -, com articulações e defasagens inesperadas que foram retrabalhadas à exaustão até a publicação de Alguma poesia, em 1930. 


\section{CAPÍTULO 3}

\section{A CAPITAL ANTIFUTURISTA (1927)}

Belo Horizonte era uma capital profundamente quieta e bem pensante. Amava o soneto, deleitava-se com sua operazinha em tempos de temporada, acatava o Santo Oficio, que censurava por sua conta os filmes, suas moças liam Ardel, Delly, a Bibliothèque de Ma Fille, a Collection Rose, não conversavam com rapazes e faziam que acreditavam que as crianças pussavam nas hortas entre pés de couve, raminhos de salsa, serralha, bertalha e talos de taioba. Havia uma literatura oficial. Os discursos de suas excelências eram obras antológicas. "Minas é um coração de ouro num peito de ferro". "Minas é um povo que se levanta". "A desopilante Comédia Humana".

Pedro Nava, BEIRA-MAR

O que salva esse aspecto caótico e neológico da vossa capital

é a sua provisoriedade. Toda a pastelaria dos edificios atuais desaparecerá pouco a pouco, absorvida pelo progresso formidável que se anuncia e realiza em Minas.

Oswald de Andrade, ENTREVISTA AO DIÁRIO DE MINAS, 1924

\section{LANTERNA MÁGICA - I BELO HORIZONTE}

Meus olhos têm melancolias,

minha boca tem rugas.

Velha cidade!

As árvores tão repetidas.

Debaixo de cada árvore faço minha cama,

em cada ramo dependuro meu paletó.

Lirismo.

Pelos jardins versailles

ingenuidade de velocípedes.

E o velho fraque 
na casinha de alpendre com duas janelas dolorosas. ${ }^{68}$

"Belo Horizonte" é o primeiro poema da série de cartões-postais urbanos publicados separadamente a partir de 1925 e depois reunidos em Alguma poesia sob o título de "Lanterna mágica". Como o objeto que lhe dá nome, o conjunto é formado por uma sequência de retratos que compõem uma cartografia sentimental do país, na qual a físionomia de diferentes lugares - Belo Horizonte, Sabará, Caeté, Itabira, São João DelRei, Nova Friburgo, Rio de Janeiro e Bahia - é delineada a partir das experiências do eu lírico ${ }^{69}$. Em "Belo Horizonte", publicado pela primeira vez em março de 1927 no Diário de Minas, a relação entre eu lírico e cidade é bastante próxima. À primeira vista, poderíamos imaginar que o eu lírico se identifica com a cidade, porque pulamos do título para o pronome possessivo de primeira pessoa antes que esta seja definida ${ }^{70}$. Essa confusão se desfaz no terceiro verso, e Belo Horizonte se revela como uma espécie de interlocutor ou vocativo, a quem (ou contra quem) se dirigem os versos. A partir daí a distância entre o eu lírico e o seu interlocutor parece se estabelecer, e é reforçada pela descrição da paisagem ("as árvores tão repetidas"), a qual pressupõe algum distanciamento do observador. $\mathrm{Na}$ passagem para a segunda estrofe, entretanto, eles voltam a se aproximar porque a cidade passa a ser descrita como se fosse uma casa, um abrigo em que o eu lírico se instala. O sétimo verso, constituído pela palavra "lirismo", intensifica a impressão de comunhão da cena, só perturbada, mesmo assim de forma sutil, pelas "melancolias" e "rugas" dos primeiros versos e pelo ponto de exclamação do terceiro, que parece pontuar um desabafo irritado - elementos que puxam para outra direção menos idílica. A discreta dissonância do quadro, cujo fundo e figura estão e não estão em acordo, mais estão do que não estão, reaparece nos últimos versos da segunda estrofe, em que, se por um lado a presença de brinquedos infantis onde esperaríamos talvez carros velozes reforça a atmosfera calma do lugar, por outro a intrusão de palavras - em particular, "versailles" e "velocípedes" - muito distintas das que até então compunham o poema faz pensar em um estremecimento na familiaridade do eu lírico com o meio à sua volta, não tão bucólico assim. Essa oscilação atinge seu ponto máximo nos

\footnotetext{
${ }^{68}$ Carlos Drummond de Andrade, Poesia 1930-62. Organização Júlio Guimarães Castañon. São Paulo: Cosac Naify: 2012, p. 86.

${ }^{69}$ Ou não-experiência, no caso da Bahia, distanciamento que também se expressa já na opção pelo nome do Estado, e não da cidade, como nos demais poemas do conjunto.

${ }^{70} \mathrm{O}$ fato de a cidade, a rigor, não possuir olhos ou boca é irrelevante, ou melhor: tão metafórico quanto os olhos terem melancolias.
} 
dois últimos versos, pois neles se fundem a imagem prosaica do fraque pendurado dentro da casinha simples e a metáfora bem menos concreta das janelas dolorosas, formando um conjunto que, como o resto do poema, divide-se entre o concreto e o abstrato, o singelo e o melancólico. Além disso, arma-se aí uma correspondência entre os olhos cheios de melancolias e as janelas dolorosas, respectivamente no primeiro e no último verso, e que sela o vínculo entre o sujeito e o espaço. Porém, o vínculo revelado pelos últimos versos aponta para uma convivência problemática, e não harmoniosa, como fazia crer a segunda estrofe. O final do poema surpreende, portanto, porque leva o conflito até então apenas sugerido ao seu ápice, sem aclará-lo nem muito menos superá-lo.

Discretamente e sem apontar para a solução, o poema traça um conflito brando e íntimo: a comunhão aparente entre eu lírico e cidade, na verdade, trai um vago mal-estar em nada semelhante ao bom humor e à alegria que caracterizaram os primeiros anos do Modernismo, em geral, e vários poemas de Alguma poesia, em específico ${ }^{71}$. "Belo Horizonte" configura, ao invés, um movimento duplo e contraditório de proximidade e distanciamento em relação à capital mineira, como se o anseio de pertencer a esta - que chega a ser descrita como uma casa -, viesse acompanhado da consciência de estar também em alguma medida apartado dela. E é justamente essa ambivalência que determina o tratamento dúbio, como veremos. O poema é composto basicamente por substantivos prosaicos e concretos, os quais estão dispostos quase sem conjunções ou coordenação (a exceção é o "e" da última estrofe, mas que não destoa da simplicidade do restante, visto que se trata de uma conjunção de sentido algo inespecífico). Ou seja, não há grandes complicações sintáticas em "Belo Horizonte", pelo contrário: predominam orações assindéticas e frases sem verbos. Por sua vez, o número reduzido de verbos (apenas quatro) e o fato de estarem todos conjugados no presente do indicativo dá a "Belo Horizonte" um aspecto de imobilidade, que o assemelha a um quadro. Quanto à escolha das palavras e à construção dos versos, há uma busca deliberada pelo prosaico. A opção pelo registro terra-a-terra garante a impressão de familiaridade do cenário, o qual, além de acolher, contamina com sua sugerida decrepitude os olhos e boca do eu lírico. O espaço é importante porque como que molda a personalidade deste, que, se se sente protegido, também sufoca e tenta dele se diferenciar, daí as idas-e-vindas. Não é por acaso, portanto,

\footnotetext{
${ }^{71}$ Em resenha publicada no calor da hora, Manuel Bandeira assinalou o equilíbrio instável encenado nos poemas do livro entre sensibilidade e ironia, cuja dinâmica se assemelharia a um "jogo automático de alavancas de estabilização". Cf. Manuel Bandeira, "Carlos Drummond de Andrade", in: da província Brasil. São Paulo: Cosac Naify, 2011, p 59. Crônicas
} 
que, apesar das referências à primeira pessoa, o pronome "eu" não aparece, afinal é da dificuldade de construção da identidade de que "Belo Horizonte" trata, através de uma formalização singela mas ambígua. O ritmo do poema também procura mimetizar essa ambivalência. Seus versos se dividem em três estrofes irregulares e são livres e brancos. "Belo Horizonte" é, desse modo, marcado por uma irregularidade rítmica acentuada. A ausência de rimas e o desencontro entre os acentos não chegam, contudo, a desorganizar a leitura, que é pausada e lenta por causa da coincidência no mais das vezes entre versos e orações (há apenas dois enjambements ao longo do poema) e da pontuação relativamente abundante (nove em onze versos) e sóbria (salvo pelo ponto de exclamação do terceiro verso). A partir de unidades desiguais quanto ao número de sílabas, o poema organiza um movimento rítmico cadenciado e moroso que atenua as dissonâncias por meio de pausas e intervalos.

A instabilidade entre o que é afirmado e o que é sugerido, entre o que é literal e o que é metafórico é constitutiva de "Belo Horizonte". De modo mais pontual, a contrapartida à impressão de estabilidade inclui a escolha das palavras "melancolias", "versailles", "velocípedes" e "dolorosas". As formas plurais "melancolias" e "dolorosas", simetricamente dispostas, uma no fim do primeiro verso e outra no fim do último, e ambas acompanhadas por substantivos concretos, funcionam como uma espécie de ponto de fuga que põe a harmonia do primeiro plano em perspectiva. Pois, além de possuírem campos semânticos afins, que se reforçam pela presença mútua, mais sugerem do que afirmam, configurando uma atmosfera melancólica a pairar sobre a cidade. Há algo nelas que se aproxima - salvo engano - dos meios-tons e alusões do Penumbrismo ${ }^{72}$. Como se sabe, o Penumbrismo foi entre nós uma espécie de prolongamento do Simbolismo e se caracterizou justamente pela "esfumatura das percepções e dos sentimentos, por meio de um verso discreto e macio"73. Tendo florescido entre 1910 e 1920 , ele antecipou em alguns aspectos e, com isso, preparou terreno para o Modernismo, cujo início é geralmente datado em 1922, ano da Semana de Arte Moderna e da publicação da Paulicéia desvairada, de Mário de Andrade. Já por causa da proximidade cronológica, há

\footnotetext{
72 A imagem das árvores repetidas e das "janelas dolorosas" também aproxima "Belo Horizonte" do gosto penumbrista: "dos temas "nobres", a poesia crepuscular passa para os "banais": o quarto do poeta; a vista encaixilhada pela janela, a praça, a árvore desfolhada, os interiores penumbrosos, a "lâmpada velada" (Hermes Fontes), o jardim dissolvido pela chuva, a névoa, a cena cotidiana". Cf. Norma Goldstein. Do Penumbrismo ao Modernismo: o primeiro Bandeira e outros poetas significativos. São Paulo: Ática, 1983, p. 11.

${ }^{73}$ Antonio Candido, Iniciação à literatura brasileira. Rio de Janeiro: Ouro sobre Azul, 2010, p. 101.
} 
pontos em comum entre os dois momentos. É o caso da preferência pelos temas cotidianos, mas também da prática do verso polimétrico e do verso livre, ambas introduzidas pelo Penumbrismo e retomadas - em outra escala, porém - pelo Modernismo. Prova dessa afinidade, poetas que principiaram penumbristas como Guilherme de Almeida, Ribeiro Couto e sobretudo Manuel Bandeira ${ }^{74}$, depois passaram para as fileiras modernistas. Como boa parte dos jovens dados às letras da sua geração, Drummond também foi influenciado pelo penumbrismo e por outras tendências finisseculares semelhantes, e chegou inclusive a escrever um livro inspirado nelas, Poemas da triste alegria, mas que não publicou. A voga - hoje tão curiosa - de escritores como Mário Pederneiras e Álvaro Moreyra atesta obliquamente a penúria literária das primeiras décadas do século XX, período em que a literatura brasileira foi dominada, com raras exceções, por um convencionalismo avesso a experimentações e que marcou o gosto médio no país ${ }^{75}$. No caso de Minas Gerais, a ascendência dessas tendências e escritores perdurou por ainda mais tempo e se tingiu, inclusive, de um inesperado sentido de contestação $^{76}$ graças ao relativo isolamento cultural em relação ao Rio de Janeiro e São Paulo, imposto pelas dificuldades de comunicação e transporte, de onde também um certo atraso de gosto entre os jovens escritores mineiros, que recebiam as últimas novidades com atraso desanimador, como gostavam de dizer ${ }^{77}$, e em parte responsável pela "curiosa modernidade mineira" identificada por Antonio Candido a propósito de escritores como Cyro dos Anjos, Drummond e Pedro Nava ${ }^{78}$.

\footnotetext{
${ }^{74}$ Manuel Bandeira diria em carta a Mário de Andrade de janeiro de 1925: "sou, de fato, de formação parnasiano-simbolista. Cheguei à feira modernista pelo expresso Verlaine-Rimbaud-Appolinaire". Marcos Antonio de Moraes (org.), Correspondência: Mário de Andrade \& Manuel Bandeira. São Paulo: EDUSP; IEB, 2001, p. 175.

75 "Parnasianismo, Simbolismo e Penumbrismo na poesia; Realismo naturalista, mundano ou regionalista, formaram um bloco de literatura convencional que marcou o gosto médio no Brasil e resistiu à mudança das estéticas renovadoras, ficando como padrão da literatura convencional durante muito tempo, com o apoio das Academias de Letras, do ensino e do próprio espírito das classes médias, contra os quais se insurgiram os modernistas". Cf. Antonio Candido, Iniciação à literatura brasileira, cit., p. 85. John Gledson também identificou a penúria da vida literária desse período ao estudar a produção de juventude de Drummond. Cf. Poesia e poética em Carlos Drummond de Andrade. São Paulo: Livraria Duas Cidades, 1981, p. 68.

${ }^{76}$ Vale lembrar as palavras ditas por Pedro Nava em 1921, quando da leitura do primeiro conto publicado por Drummond: o decadentismo identificado por ele no conto era então "o instrumento mais à mão para protestar contra o parnasianismo, o imobilismo, o sonetismo que curarizavam o Brasil (...) provocação, desafio à delicadeza da cidade". Cf. José Maria Cançado, Os sapatos de Orfeu: biografia de Carlos Drummond de Andrade. São Paulo: Ed. Página Aberta Ltda, 1993, p. 82.

${ }^{77}$ A revista, $\mathrm{n}^{\circ} 1,1925$. Apud Maria Zilda Cury, Horizonte Modernistas: o jovem Drummond e seu grupo em papel jornal. Belo Horizonte: Autêntica, 1998, p. 51.

78 "A curiosa modernidade mineira, feita com o sumo dos clássicos, temperada na leitura atenta mas divertida de velhos livros, que eles sabem transformar em adubo da prosa mais atual". Cf. Antonio Candido, "Drummond prosador". In: , Recortes. São Paulo: Companhia das Letras, 1993, p.13. Sobre as
} 
O contraponto a essa imagem provinciana da cidade é dado, no poema, pela presença das palavras "versailles" e "velocípedes". Ambas apontam para outra direção, a da modernidade. Por um lado, os jardins versailles revelam a influência estrangeira sobre Belo Horizonte, cujo projeto se inspirara em Paris - então o umbigo do mundo - e em Washington D. C., e que fora construída com o intuito de centralizar as decisões políticas e econômicas do Estado. Mas, a despeito das aparências, tratava-se no fundo de uma modernidade relativa e incipiente a qual dava à simetria das ruas e da vegetação o ar monótono e repetido que reponta em diversos momentos ao longo da obra de Drummond. Por outro lado, as ingenuidades de velocípedes se referem, em tom diminuído e irônico, à velocidade, símbolo da modernidade em geral e do Futurismo em particular. Porém, ao invés de uma celebração à maneira de Marinetti, a velocidade é representada aqui por uma palavra dela derivada, mas que em certo sentido denota o seu contrário, - um brinquedo infantil. Além disso, a sonoridade esdrúxula do termo sobressai e se destaca do resto, isolando-o foneticamente e marcando o seu desentrosamento com o meio. $\mathrm{O}$ poema nos lança portanto, sem alarde e de chofre, para o coração dos temas modernos, e ainda por cima de forma irônica. Ou por outra, diferentemente do fascínio diante do processo de modernização e industrialização que resultava muitas vezes em obras ultramodernas e... descoladas do contexto local, em "Belo Horizonte" os elementos modernos aparecem condicionados e constrangidos pelo ritmo lento e caipira da capital mineira, daí que pareçam um tanto fora de lugar e artificiais. Há, em outras palavras, um aproveitamento cum granus salis e muito matuto não só dos temas, mas também dos procedimentos formais mais tipicamente modernos que não ignora o acanhamento das origens, mas que o assume sem entretanto idealizá-lo, e que está a serviço da invenção literária da cidade de Belo Horizonte ${ }^{79}$. No plano mais estritamente formal, esse

relações entre o Modernismo e Minas, Cf. Ivan Marques, Cenas de um modernismo de província: Drummond e outros rapazes de Belo Horizonte. São Paulo: Editora 34, 2011, especialmente pp. 9-42.

${ }^{79}$ Adaptação da expressão "invenção literária da cidade São Paulo", cunhada por Antonio Candido. Cf. "A educação pela noite", in: __, A educação pela noite. Rio de Janeiro: Ouro sobre Azul, 2011, p. 16. Comentando Macário, peça de Álvares de Azevedo, Candido observa entre suas dimensões a instauração de um espaço ficcional, e acrescenta: "com isto, deu corpo a um processo em curso entre os moços estudantes, enclausurados num lugar sem interesse, onde a sua energia transbordava tanto na boemia e na rebeldia estética, quanto na imitação de Byron. O noturno aveludado e acre do Macário suscitou a noite paulistana como tema, caracterizado pelo mistério, o vício, a sedução do marginal, a inquietude e todos os abismos da personalidade. Tema que fascinou gerações numa dimensão quase mitológica, repontando em muitos poemas de Mário de Andrade e, nos nossos dias, em sambas de Adoniran Barbosa e Paulo Vanzolini, filmes de Walter Hugo Khoury, quadros de Gregório Correia, contos de João Antonio". Meu palpite é que algo semelhante ocorreu no caso de Belo Horizonte, e que a imagem tediosa forjada por Drummond ressoa nas descrições de Cyro dos Anjos e Pedro Nava, nas paisagens de Alberto da Veiga Guignard e em algumas canções de Milton Nascimento, Lô Borges e Fernando Brant. 
aproveitamento diz respeito em particular à escolha do vocabulário e à carpintaria dos versos. Visando traduzir a familiaridade entre eu lírico e cidade, a opção pelo registro prosaico converge, em outro plano, com a busca promovida de maneira sistemática pelo Modernismo por uma linguagem menos afetada e retórica, dando continuidade também e por tabela à busca pela naturalidade timidamente iniciada com o Penumbrismo. Os coloquialismos, os "erros", as expressões idiomáticas, as colagens - foram formas e pesquisas encampadas pelo Modernismo para se opor à linguagem solene e grandiloquente das tendências em voga até aquele momento e como que personificadas pelo Parnasianismo. Assim, já ao se decidir por palavras do dia-a-dia, "Belo Horizonte" se contrapunha a essa literatura convencional e acadêmica. Algo análogo vale para os seus versos. A justaposição deles praticamente sem conjunções ou subordinação afina com a parataxe, procedimento antiquíssimo e, no entanto, central para a Poesia moderna, como se sabe. Mas, de novo: o recurso aqui acaba amaciando o conflito porque não o explicita, apenas o sugere, entroncando por aí, aliás, no veio penumbrista da nossa tradição pré-modernista. Finalmente, no que se refere ao tema, o poema retoma aquele que talvez seja o mais característico da arte moderna, a relação entre indivíduo e cidade. Entretanto, a cidade em questão é a pacata Belo Horizonte do começo do século XX, projetada sob o signo da racionalidade moderna, mas culturalmente tacanha, o que redimensionava a relação, renovando o tema.

Nesse processo de assimilação das conquistas modernas, "Belo Horizonte" se beneficiou da existência de um antecedente ilustre: Paulicéia desvairada, livro que Drummond conhecia pelo menos desde $1923^{80}$ e que o influenciou em mais de um sentido. Dificilmente se pode superestimar a importância do livro de Mário para o nosso Modernismo. Ao mobilizar sugestões das vanguardas europeias para exprimir a temática local, ele pôs em movimento a dialética do geral e do particular que, segundo Antonio Candido, definiria a originalidade do nosso Modernismo ${ }^{81}$. Sinal da importância do livro no panorama literário da época, cujo marasmo rompeu, Drummond confessaria logo na segunda carta enviada a Mário, de novembro de 1924, a admiração e a importância de Paulicéia para sua atividade poética. E tanto é verdade que, mesmo tendo sido escrito por

\footnotetext{
${ }^{80}$ Em 20 de janeiro de 1923, o Diário de Minas noticiava: "numa roda à porta do Alves, Aníbal Machado, Carlos Drummond, Alberto Campos, Abílio Barreto, Milton Campos falam da Paulicéia desvairada de Mário de Andrade". Apud Maria Zilda Cury, id., ibid., p. 75.

${ }^{81}$ Antonio Candido, "Literatura e cultura de 1900-1945", in: história e teoria literária, Rio de Janeiro: Ouro sobre Azul, 2011, p 127. Literatura e sociedade: estudos de
} 
volta de 1927, quando as conquistas modernistas começavam a se rotinizar, "Belo Horizonte" é não obstante tributário da liberdade do livro de 1922, cuja publicação foi um divisor de águas, além de um escândalo. Em termos formais, Paulicéia desvairada promoveu uma afirmação enfática e sistemática do verso livre, conquistando-o definitivamente como meio de expressão para os mais moços. A campanha esboçada pelo Penumbrismo e depois entronizada violentamente pelo Modernismo resultou afinal na vitória do verso livre, e foi tal que, diferentemente dos poetas que se formaram dentro da tradição das regras de metrificação como o próprio Mário de Andrade e Manuel Bandeira por exemplo, Drummond - alguns anos mais jovem - já se formou fora dela, e dizia mesmo ignorá-la quando dos seus primeiros ensaios poéticos. É claro que isso se deveu também e em larga medida à sua formação escolar algo acidentada, diferente da dos modernistas que estudaram em colégios tradicionais. De qualquer maneira, a insubordinação mental - atribuída, como se sabe, pelo colégio em Friburgo que o expulsou $^{82}$, em 1919 - fez de nosso Autor um "rebelde da primeira hora"83, formado dentro da órbita do Penumbrismo e mais tarde do Modernismo, e que desde cedo se pôs ao largo da tradição poética mais convencional. Na verdade, como notou Antonio Candido, o verso livre correspondia à sua natureza poética mais profunda, seca e sem ênfase, e de que "Belo Horizonte" é um bom exemplo ${ }^{84}$. Quanto ao assunto, Paulicéia reconfigurou, grossíssimo modo, a relação indivíduo-cidade a partir de um espelhamento mútuo entre a subjetividade arlequinal e a efervescente metrópole paulistana. Já no poema de Drummond não se trata propriamente de espelhamento, como estamos vendo, mas de uma proximidade problemática.

As diferenças de "Belo Horizonte" em relação aos poemas da Paulicéia desvairada também são consideráveis. Ou por outra, se é verdade que ambos se valem do verso livre, o uso que cada um faz do recurso é bastante distinto no pormenor. Como se sabe, a maior parte dos poemas do livro de 1922 são compostos pelo chamado "verso harmônico". No "Prefácio interessantíssimo", híbrido de poética e estética publicado como prefácio à Paulicéia, Mário distingue o verso melódico do harmônico, afirmando

\footnotetext{
82 O episódio é narrado por José Maria Cançado, Cf. do Autor, op. cit., p. 69. Sobre ele, aliás, Drummond diria: "a saída brusca do colégio teve influência enorme no desenvolvimento dos meus estudos e de toda a minha vida. Perdi a Fé. Perdi tempo. E sobretudo perdi a confiança na justiça dos que me julgavam".

${ }^{83}$ A expressão é de Sérgio Buarque de Holanda, Cf. "O mineiro Drummond - II", in: , O espírito e a letra: estudos de crítica literária 1948-1959. Vol. 2. Org. Antonio Arnoni Prado, São Paulo: Companhia das Letras, 1996, p. 563.

${ }^{84}$ Antonio Candido, Iniciação à literatura brasileira, cit., p. 101.
} 
que, ao contrário do primeiro, o segundo é composto por "palavras sem ligação imediata entre si" 85 , o que criaria uma combinação de sons simultâneos semelhantes a acordes. Tratava-se, desse modo, de justapor as partes do verso com o fito de grafar tal e qual o simultaneísmo do inconsciente, que era para Mário então a origem do lirismo. Diversamente, a justaposição sem tecido de ligação em "Belo Horizonte" resulta num verso alusivo e antimelódico que visava exprimir o mal-estar difuso e que mimetizava, não o inconsciente, mas o ritmo pachorrento da cidade. Além disso, é óbvio que a diferença de datas também os afasta. Publicado pela primeira vez cinco anos depois da Paulicéia, o poema foi escrito em um contexto muito diverso do clima de guerra do começo da década de 20, tendo tempo para trabalhar com maior distanciamento e recuo as inovações que o livro pioneiro de Mário conquistou na marra. Com efeito, quando "Belo Horizonte" apareceu em 1927, o Modernismo já ia numa fase de estabilização dos seus temas e procedimentos, produto da dinâmica aceleradíssima por ele mesmo instituída. Prova disso, apenas um ano depois, em 1928, Mário - atinando com a mudança - perguntava em carta de 28 de fevereiro a Drummond se algumas das coisas escritas por ele até aquele momento não teriam vindo "meio de cambulhada", com o que aliás nosso Autor concordaria, tanto assim que deixou vários poemas de lado quando da organização de Alguma poesia, reconhecendo que algumas das suas coisas haviam envelhecido precocemente $^{86}$. O "brasileirismo de estandarte" identificado por Mário na carta era o reflexo da consolidação vitoriosa do Modernismo àquela altura e consistia no refluxo dos seus aspectos mais superficiais e pitorescos. O morador da rua Lopes Chaves alertava para a voga e para a consequente diluição desses aspectos, tão mais perigosos porquanto o "espírito individualistamente contemplativo e observador" do amigo não combinava com eles.

Inserido num momento de acirramento do debate modernista, "Belo Horizonte" pode ser lido como uma espécie de resposta - a meu ver, original e interessante apesar, ou melhor, por causa da sua tibieza - aos dilemas com que iam se deparando os modernistas para tentar dar uma forma moderna à matéria brasileira. Para representar a

\footnotetext{
${ }^{85}$ Mário de Andrade, Poesias completas. Edição crítica de Diléia Zanotto Manfio, Belo Horizonte; São Paulo: Itatiaia; Editora da Universidade de São Paulo, 1987, p. 68.

${ }^{86}$ Respondendo à pergunta de Mário, Drummond assume: "[...] como você disse muito bem, seria besta que eu aparecesse repetindo o que mil sujeitos já disseram antes de mim, e de que infelizmente as minhas coisas estão cheias no período Minha terra tem palmeiras. Meus versos guardados demais na gaveta ficaram velhos". Lélia Coelho (org.), Carlos \& Mário: correspondência entre Carlos Drummond de Andrade inédita - e Mário de Andrade: 1924-1945. Rio de Janeiro: Bem-Te-Vi, p. 324.
} 
capital mineira, ela própria meio moderna meio provinciana, o poema aproximava elementos modernos da realidade e conquistas modernistas - a incipiente modernização belorizontina, o cromo de província e o verso livre -, de elementos não-modernos e esquemas ultrapassados - o caipirismo da cidade e o macio verso penumbrista. Desse modo, entravam em relação procedimentos modernos e esquemas do passado, modernização e matéria atrasada, requalificando-se de forma recíproca, mas sem se acomodarem completamente. $\mathrm{O}$ moderno assim configurado não se dissociava inteiramente do não-moderno, mantendo com ele certa reversibilidade, que está espalhada por praticamente toda a produção de Drummond dessa época e que constitui um dos eixos do seu livro de estreia, Alguma poesia. E de fato, quando o livro foi publicado, Mário rapidamente identificou no conjunto de poemas essa ambivalência entre atraso e modernidade, fixando-a em termos psicologizantes. Primeiro, em carta de 1930, assinalou: "o contraste é que, embora desprezando um bocado essa vida besta, você se compraz nela" ${ }^{87}$. Depois, no importante ensaio "A poesia em 1930", completou o achado da carta ao notar que, assim como era ambivalente a relação de Drummond com a vida besta - ora ridicularizada ora identificada com o próprio modo de ser -, também o era a sua relação com a vida moderna e com as exigências desta, diante das quais o poeta mineiro, ser de ação pouca e muito funcionário público, teria desenvolvido a "consciência penosa" $^{88}$ da sua inutilidade. Porém, se fazia parte do pensamento poético de Drummond $^{89}$, como queria Mário, essa ambivalência era também e antes um dado da realidade, que nosso Autor reinventou literariamente.

Belo Horizonte reaparece em Alguma poesia no "Jardim da praça da Liberdade". Publicado pela primeira vez em Terra Roxa e outras Terras em setembro de 1926 - antes, portanto, de "Belo Horizonte" -, ele foi incluído no livro alguns poemas à frente de "Lanterna mágica", mais ou menos na metade do conjunto, o que comprova que a organização do livro não seguiu o critério cronológico, mas foi o resultado de uma

\footnotetext{
${ }^{87}$ Lélia Coelho (org.), id., ibid., 2002, p. 390.

${ }^{88}$ Mário de Andrade, "A poesia de 30", in: Aspectos da literatura brasileira. Belo Horizonte: Editora Itatiaia, 2002, p. 102.

${ }^{89}$ Vale lembrar a formulação precisa de Vagner Camilo: "Drummond joga com perspectivas diversas ou antagônicas sem alinhar-se a uma em particular, o que não implica omissão, recusa em tomar partido, mas uma forma própria de sua poética e raciocínio dialéticos ou mesmo aporéticos". Vagner Camilo, "Figurações espaciais e mapeamentos na lírica de Drummond", in: ReDObRa, v. 13, 2014, p. 54
} 
organização mais profunda da produção do Autor até aquele momento.

Verdes bulindo.

Sonata cariciosa da água

fugindo entre rosas geométricas.

Ventos elíseos.

Macio.

Jardim tão pouco brasileiro... mas tão lindo.

Paisagem sem fundo.

A terra não sofreu para dar estas flores.

Sem ressonância.

$\mathrm{O}$ minuto que passa

desabrochando em floração inconsciente.

Bonito demais. Sem humanidade.

Literário demais..$^{90}$

O poema se abre com a descrição do jardim da praça. Como em "Belo Horizonte", os versos são livres e brancos. Além disso, há poucos verbos - "bulindo", "fugindo", "sofreu", "dar" e "passa desabrochando" - e uma única conjunção no último verso da primeira estrofe ("mas"). Com a exceção da passagem do segundo para o terceiro e do décimo para o décimo primeiro, onde ocorrem enjambements dos verbos, os demais versos - quase todos frases sem verbos - sucedem-se por justaposição. As duas primeiras estrofes se aproximam por isso da descrição de um quadro, mas que, ao contrário da imobilidade de "Belo Horizonte", procura captar o movimento natural do jardim. Porém, esse movimento é tão sutil e harmonioso que quase não se dissocia da imagem e não perturba a plasticidade do conjunto, fazendo inclusive duvidar da sua naturalidade. Outra diferença em relação a "Belo Horizonte" é o vocabulário. Ao invés de palavras prosaicas, o poema é composto por termos algo rebuscados - "bulindo", "cariciosa", "elíseos", "ressonância" e "inconsciente" - e ligados ao universo artístico - "sonata", "geométricas" e "literário". A construção dos versos se assemelha, assim, a um trabalho de composição que visa captar a beleza e a simetria do jardim, embora com unidades assimétricas do ponto de vista da quantidade de sílabas, o que sugere um desencontro entre representação e realidade. Para atestar a perfeição do cenário, também são convocados todos os sentidos,

${ }^{90}$ Carlos Drummond de Andrade, Poesia 1930-62, cit., pp. 106-108. 
menos o paladar e o olfato (que, no entanto, é indiretamente invocado pelo desabrochar das flores): o verde da vegetação e a geometria natural das rosas se aproximam da pintura, o correr da água ganha dimensão musical e o próprio vento tem textura, macia ainda por cima. O exagero e a afetação da descrição acabam ressaltando a artificialidade do jardim, que em função mesmo dela é considerado lindo, mas pouco brasileiro. Há aqui uma espécie de salto que liga a beleza e a simetria do jardim a um como que déficit de nacionalidade. Como em "Belo Horizonte", portanto, o jardim francês não se mistura com o meio amorfo à sua volta, explicitando o desentrosamento.

(Pobres jardins do meu sertão, atrás da Serra do Curral!

Nem repuxos frios nem tanques langues, nem bombas nem jardineiros oficiais.

Só o mato crescendo indiferente entre sempre-vivas desbotadas e o olhar desditoso da moça desfolhando malmequeres.)

A terceira estrofe, entre parêntesis como algo secundário ou menos importante, apresenta outros jardins, os do sertão atrás da serra do Curral. Logo compreendemos o motivo de a estrofe vir entre parêntesis. É que os jardins do sertão se contrapõem ao da praça da Liberdade: a pobreza que os caracteriza e com a qual se compadece (ironicamente?) o eu lírico nada tem a ver com os cuidados - repuxos, tanques, bombas e jardineiros oficiais - que cercam o jardim da praça. Essa oposição também se expressa no nível formal. De um lado, o vocabulário é mais prosaico e simples, exceto no terceiro e no quarto versos, que não por acaso se referem ao jardim da praça. E de outro, o ponto de exclamação no segundo verso rompe com a frieza das descrições das primeiras estrofes e parece marcar uma aproximação entre o eu lírico e os jardins do sertão, o que também é indicado pela presença do pronome possessivo no primeiro verso. Mas, a despeito dessa afinidade, que poderia sugerir uma intimidade, a identidade desses jardins é dada apenas em negativo, pela repetição das conjunções negativas. Ou seja, a identidade deles é definida a partir da do jardim da praça e em oposição a ele, portanto sem uma identidade própria. Essa ausência é reforçada pelo advérbio "só" do penúltimo verso da estrofe, que assinala a falta de um traço que dê unidade ou coerência ao conjunto: "só o mato crescendo indiferente entre sempre-vivas desbotadas". A isso se acrescenta, de forma 
inesperada e abrupta, a imagem da moça, muito mineira ${ }^{91}$, desfolhando malmequeres (nunca bem-me-queres) e lançando olhares. Obliquamente, trata-se de mais uma oposição ao jardim da praça: o sofrimento causado pela moça contrasta com a falta de sentimentos do jardim da praça, cuja terra sequer sofre para dar flores.

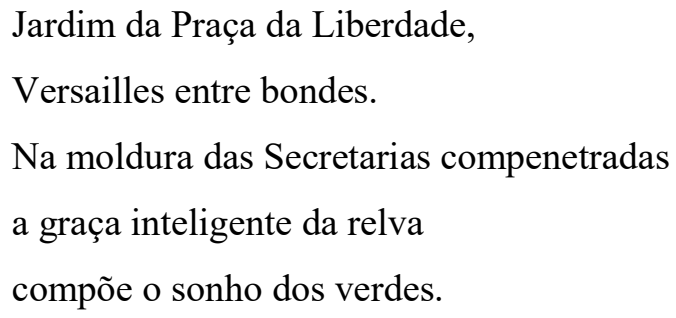

$\mathrm{Na}$ quarta estrofe, o foco do poema volta para o jardim da praça, onde cada coisa tem o seu lugar. Aí se revela também o vínculo entre a aparência moderna da cidade, com jardins e bondes, e o seu espírito burocrático. Concebida para ser a capital do Estado, Belo Horizonte era habitada basicamente por funcionários públicos nas primeiras décadas após sua inauguração em 1984, e assim permaneceu até mais ou menos a década de 30, o que dava a ela sua pachorra burocrática, além de defini-la como um importante centro da política mineira, aliás concentrado nas imediações da praça da Liberdade. Como consequência, sua vida intelectual se desenvolveu à sombra dos gabinetes políticos e colada às redações dos diários oficiais, com destaque para o Diário de Minas, órgão do Partido Republicano Mineiro onde nosso Autor trabalhou e onde foram publicados inúmeros poemas, artigos e resenhas do grupo do Estrela, nome do bar frequentado entre outros por Drummond, Alberto Campos, Emílio Moura, João Alphonsus e Pedro Nava. Da cooptação desses jovens intelectuais mineiros, a maioria dos quais oriundos de famílias tradicionais, vindos do interior e ainda cursando a faculdade, resultou a liga singular de repartição pública e boemia, de oficial e oficioso ou ainda de rotina e quimera, como Drummond formularia anos depois a acomodação por cima das tensões inevitáveis entre o expediente na repartição e as aspirações artísticas modernas, com o que estas pressupunham de espírito crítico e autonomia ${ }^{92}$. Algo dessa convivência a princípio

\footnotetext{
${ }^{91}$ Em mais de uma entrevista, Drummond se referiu à rejeição e à dificuldade de se aproximar das moças belorizontinas da sua juventude. Cf. por exemplo, Maria Zilda Cury, op. Cit., p. 22.

92 Maria Zilda Cury formula a tensão nos seguintes termos: "o fato de o grupo modernista mineiro ter assumido uma linha de modernização abraçada por parte das elites no poder não anula o fato de efetivamente ter empreendido uma ação vivificadora no panorama cultural em que atuava. Dentro do momento histórico em que viviam, o espaço de atuação desses jovens talvez significasse a "consciência possível" de um grupo de origem familiar "bem-nascida" e "bem-educada" e ansioso por participação. Sua proposta de nacionalismo estético (e político), embora tingida por autoritarismo excludente, não deixa também de significar uma preocupação com a afirmação modernista do país e de seus valores". Maria Zilda
} 
incompatível, mas bastante familiar transparece, em sua versão bem-humorada e gaiata, nos dois últimos versos da estrofe, onde o nonsense irrompe do ambiente sério e concentrado, embaralhando trabalho e galhofa. A compenetração grave dá asas à imaginação, que a partir da imagem do jardim voa:

\section{PROIBIDO PISAR NO GRAMADO}

Talvez fosse melhor dizer:

\section{PROIBIDO COMER O GRAMADO}

A prefeitura vigilante

vela a soneca das ervinhas.

E o capote preto do guarda é uma bandeira na noite estrelada de funcionários.

De repente uma banda preta

vermelha retinta suando

bate um dobrado batuta

na doçura

do jardim.

\section{Repuxos espavoridos fugindo.}

Se contrasta com o cenário insípido e burocrático, o devaneio também é de certa forma estimulado por uma realidade que teimava em conservar elementos contraditórios, no caso o jardim da praça da Liberdade e os do Sertão. Como em "Belo Horizonte", portanto, os contrastes rebarbativos da capital mineira dão lastro às ambiguidades da representação, com a diferença de que lá isso era feito através da articulação de procedimentos modernos e não-modernos, enquanto aqui é a imaginação do eu lírico que, em contraposição à organização rígida do jardim da praça, aos poucos se divorcia do cenário, estabelecendo uma descrição fantasiosa. Cada um à sua maneira, ambos exploram poeticamente as dubiedades - no primeiro, entre provincianismo e modernidade e, no segundo, entre rotina e quimera (uma variação da outra?) - as quais não eram só da cidade, mas do país como um todo. Ou por outra, é como se a convivência descompassada, em um, entre o processo de modernização e o ritmo da cidade e, em outro, entre o jardim da praça da Liberdade e os do Sertão definisse metonimicamente a

Cury, op. cit., p. 137. Cf. Também o estudo de Sérgio Micelli, Intelectuais e classe dirigente no Brasil (1920-1945). São Paulo: Difel, 1976. 
identidade de Belo Horizonte e, de modo mais amplo, a do Brasil. E o mais interessante é que a questão da identidade com o país - em ampla circulação naquele momento - não é tratada em Alguma poesia nem com ufanismo, como entre muitos modernistas do mesmo período, nem com esnobismo antinacionalista, como o do jovem Drummond, mas a partir da internalização estrutural das ambiguidades, podendo pender ora para o lado da inadequação, a exemplo em "Belo Horizonte", ora para o lado engraçado, a exemplo do "Jardim da praça da Liberdade", ora para a combinação dos dois, a exemplo de "Explicação". Em todos, porém, o foco reside na convivência desencontrada, para a qual nosso Autor tinha um faro prodigioso, como estamos vendo. Em "Jardim da praça da Liberdade", o quadro formado na penúltima estrofe pelo sono da vegetação ao som da banda no jardim revela esse gosto pela incongruência, no caso quase beirando o surrealismo. Já o verso final, uma espécie de chave-de-ouro delirante, sela o abismo entre representação e realidade ${ }^{93}$

Esse recurso à fantasia também visa a uma fecundação do meio, de modo a tentar escapar da pasmaceira da vida besta mineira, que sufoca e da qual o eu lírico procura, como em "Belo Horizonte", diferenciar-se. Nesse sentido, a injeção de fantasia nas coisas banais se insere em uma certa ânsia de evasão, difusa pelo livro e aliás notada por Mário em seu ensaio "A poesia em 1930"94. Em geral, esse sentimento se combina com o distanciamento físico e/ou espiritual do eu lírico, que observa bastante (como se sabe, os olhares atravessam Alguma poesia, a começar pelo poema de abertura, o "Poema de sete faces", em que a volúpia do olhar contrasta com a falta de jeito do dizer, atribuído no fim ao conhaque e à lua) mas que está via de regra apartado do que descreve, como se se colocasse em um ponto externo (mas externo ao quê? A Minas? Ao Brasil?). É o caso, por exemplo, do "Jardim da praça da Liberdade", em que, a despeito da afinidade com os jardins do sertão, não sabemos exatamente onde o eu lírico está (numa repartição com vista para o jardim da praça? Na praça? No sertão?). Quando andam juntas, a separação, a observação à distância e a descrição fantasiosa formam uma constelação que configura

\footnotetext{
${ }^{93}$ Em carta de 1926 a Drummond, Mário afirmou sobre o último verso de "Jardim da praça da Liberdade": "não gosto por inteiro desse poema. Quero dizer que não gosto muito porque também gosto dele e sei que é bom. Engraçado que tenho a sensação de que a poesia acaba no penúltimo verso e que o último está demais. E repare que é de fato apenas mais uma imagem. Não acho que ajunte nada ao poema". Lélia Coelho (org.), op. cit., p. 234. Porém, Drummond respondeu, com segurança: "o último verso quis com ele significar a reação da paisagem estilizada contra o brasileirismo lustroso da banda de música. O poema pode acabar antes dele, mas acabando depois fica melhor". Id., ibid., p. 241.

${ }^{94}$ Mário de Andrade, "A poesia em 1930", cit., p. 105.
} 
espacialmente o egotismo profundo de Alguma poesia, onde o eu lírico é no mais das vezes um mero observador e onde, ao contrário de livros como Sentimento do mundo (1940) e A rosa do povo (1945), quase não há a ocorrência de ruas e logradouros públicos, o que indica o caráter mais intimista do conjunto de $1930^{95}$. O próprio devaneio não deixa de ser um resultado desse isolamento. Antonio Candido viu na tendência a fantasiar uma diferença significativa de Drummond em relação aos modernistas em geral e a Mário de Andrade em particular, os quais procuravam "fixar o cotidiano a fim de obterem um momento poético suficiente em si mesmo"96. Drummond, ao contrário, procederia a uma "fecundação e a uma extensão do fato, para chegar a uma espécie de discreta epopeia da vida contemporânea". Porém, no "Jardim da praça da Liberdade" essa operação também acaba por depreciar o fato que servira de ponto de partida, isto é, o jardim da praça, cuja monotonia é ressaltada pelo contraste com os devaneios do eu lírico. Desse modo, armase um movimento duplo de adesão e recusa, em que o dado local é trazido à tona, o que faria pensar em uma valorização, mas depois é relativizado pelo desdobramento do poema como tedioso e sem graça ${ }^{97}$.

A despeito das diferenças a separá-los, tanto em "Belo Horizonte" quanto em "Jardim da praça da Liberdade" encontramos nosso Autor às voltas com procedimentos, temas e questões propriamente modernistas. Em contrapartida, também há em ambos uma boa dose de caipirismo: no primeiro Drummond opera a aproximação intencionalmente desajeitada entre Penumbrismo e Modernismo, ao passo que no segundo explora as dubiedades da capital mineira a partir da imagem de um jardim. Por caminhos diferentes - em um caso através da melancolia e no outro, da fantasia hipertrofiada - mas com sentidos semelhantes, nos dois acompanhamos o autor de Alguma poesia testando a

\footnotetext{
${ }^{95}$ Como contraponto ao que ocorre em Alguma poesia, Cf. os estudos de Vagner Camilo sobre o espaço: "Figurações espaciais e mapeamentos na lírica de Drummond", in: ReDObRa, cit., pp. 35-66, e "A cartografia lírico-social de Sentimento do Mundo", in: Revista USP. São Paulo, no 53, março/maio 2002, pp. 64-75.

96 Antonio Candido, "Inquietudes na poesia de Drummond". In: , Vários Escritos. Rio de Janeiro: Ouro sobre Azul, 2011, p. 84.

97 Sérgio Buarque de Holanda identificou uma dinâmica semelhante como um dos traços da poética de Drummond: "O que ocorre, no caso de Drummond, é que um mesmo motivo (mas este invariável e fixo) é abordado em várias formas distintas. Não raro (ia dizendo: em regra) o tema enuncia-se já nos dois ou três versos iniciais, para ser iluminado de pontos divergentes. Não é, assim, uma indefinida procura que eles nos oferecem, mas um esforço de exaustiva elucidação". Cf. "O mineiro Drummond - II", in: Sérgio Buarque de Holanda, O espírito e a letra: estudos de crítica literária 1948-1959. Vol. 2, org. Antonio Arnoni Prado, São Paulo: Companhia das Letras, 1996, p. 563.
} 
combinação das conquistas do Modernismo com o cenário pachorrento da Belo Horizonte do começo do século e com o seu caldo de cultura tacanho, com o qual não rompera a fím justamente de ultrapassá-lo. Dito de outro modo, é como se, interessado em superá-la, Drummond não abandonasse inteiramente a experiência da acanhada vida intelectual mineira, em particular da vivida na órbita dos principais diários, da qual participou ativamente, mas a mobilizasse com distanciamento irônico, aproximando-a das conquistas do Modernismo para ressaltar sua tosquice. Pelo mesmo passo, ficava assinalado o que havia de relativo e artificial na vigência do moderno na capital mineira do começo do século. É algo desta convivência problemática, salvo engano, que os dois poemas comentados dão a ver, o que lhes garante interesse e pertinência enquanto matéria de reflexão ${ }^{98}$. De modo mais amplo, Drummond estava se debatendo nesses dois poemas da década de 20 com a variante mineira da diferença brasileira, com a qual Mário e Oswald também tiveram em certa altura que se haver, só que em sua versão paulistana ${ }^{99}$. Daí que, mesmo divergindo do tradicionalismo anti-tradicional do primeiro e do otimismo desbragado do segundo, tivesse que lidar com questões parecidas com as enfrentadas pelos dois. E, de certa forma a solução por ele encontrada - improvisar e avançar uma estética moderna partindo do debate da época - não deixa de se assimilar com a de Mário e de Oswald, ainda que com um alcance modestamente menor, sugerindo uma diferença em relação ao Modernismo paulista, considerado quem sabe menos provinciano do que o correspondente mineiro, - a descrição feita vários anos depois na forma de crônica da caravana dos burgueses agitados que excursionou por Minas e em visita à qual conhecera Mário e Oswald revela um deslumbramento desse tipo ${ }^{100}$.

Nesse sentido, a representação literária da Belo Horizonte do começo do século se revela estratégica porque formaliza o caráter incipiente da modernização mineira,

\footnotetext{
${ }^{98}$ Formulação adaptada de Roberto Schwarz. In: _, Ao vencedor as batatas: forma literária e processo social nos inícios do romance brasileiro. São Paulo: Livraria Duas Cidades/Editora 34, 2000, p. 70.

${ }^{99}$ Cf. Vinicius Dantas, "Desmanchando o naturalismo: capítulos obscuríssimos da crítica de Mário e Oswald". In: Novos Estudos, São Paulo: CEBRAP, n 57, julho 2000, p. 9-27.

${ }^{100}$ Cf. Carlos Drummond de Andrade, "Suas Cartas". In: , Poesia e prosa, Rio de Janeiro: Editora Nova Aguilar, 1992, p. 1346. Vale lembrar que em sua descrição da caravana paulista Pedro Nava exprimiu um deslumbramento semelhante. Cf. Pedro Nava, Beira-mar. Rio de Janeiro: Editora Nova Fronteira, 1993, p. 122. Da parte dos modernistas paulistas, ou mais especificamente, de Mário de Andrade havia uma crença, simétrica mas oposta, de que Belo Horizonte era ao menos em parte responsável pelo modo de ser de Drummond. É o que se depreende de uma carta enviada por Mário a Drummond em 1928, em que incentivava o poeta mineiro a aceitar um convite de trabalho em São Paulo: "quem sabe se o contato com uma cidade de trabalho, no meio nosso dum trabalho cotidianizado e corajoso, você tem coragem pra uma organização e abandona essa solução a que Macunaíma chegou só depois de muito gesto heroico e muita façanha: a de viver o brilho inútil das estrelas do céu”. Lélia Coelho (org.), op. cit., p.331.
} 
contrapondo-a tacitamente a de São Paulo, cujo ritmo do processo de modernização foi outro, como se sabe ${ }^{101}$. Quer dizer, Drummond tomava os referentes modernos mais próximos, a saber: a cidade de São Paulo e a Paulicéia desvairada, de Mário de Andrade - que por sua vez se espelhavam nos grandes centros e nas vanguardas europeias, respectivamente - como termo de comparação para a modernização ainda mais titubeante da capital mineira e de sua vida mental, em um processo de adaptação de segundo grau cheio de ironias objetivas, que ele soube recriar literariamente. Mas não é só da representação de São Paulo que a de Belo Horizonte criada por Drummond se distingue. Ela também se diferencia bastante do chamado cromo de província, largamente praticado pelos modernistas, em geral, e por Oswald de Andrade, em particular. Pois, se retratava, como eles, as contradições de uma realidade dividida entre atraso e modernidade, a representação da capital mineira plasmada por Drummond foge do pitoresco e do superficialismo em que por vezes resvalam alguns cromos modernistas e, em particular, alguns de Oswald. Isso, porque diferentemente deles, em que há no mais das vezes um distanciamento entre o cenário descrito e a voz poética, que não por acaso tende à objetividade no caso de Oswald e que pode, por isso mesmo, passar com mais facilidade por cima dos antagonismos da matéria - diferentemente disso, nos poemas aqui analisados a subjetividade está presente, mesmo que não de maneira explícita, e está inserida no ambiente, constituindo um ponto de vista interno e um tratamento mais próximo, o que não significa evidentemente uma vantagem em si, mas possibilita novas perspectivas. Como vimos, nesses poemas o eu lírico não está fora da capital mineira, mas é como que condicionado por ela e, de uma forma ou de outra, internaliza suas antinomias, que são retrabalhadas esteticamente. Neles, enfim, a problemática da identidade individual incorpora e espelha a questão da identidade da capital mineira, dilacerada entre atraso e modernidade.

Sem abrir mão do desejo de incluir Minas no mapa da arte moderna, mas consciente de que Belo Horizonte não era São Paulo nem Paris, Drummond procurou, em suma, forjar um Modernismo provinciano que não abstraísse os desencontros implicados nesta transplantação. O atravancamento recíproco que os termos se impõem trata, pelo contrário, de especificar ironicamente a curiosa modernidade mineira.

101 Sobre o tema, Cf. Paul Singer, Desenvolvimento econômico e evolução urbana. São Paulo: Editora Nacional, 1968. 


\section{CAPÍTULO 4}

\section{ENTRE A PROSA E A POESIA (1931)}

"Outubro 1930" foi publicado pela primeira vez no Estado de Minas em maio de 1931 - no calor da hora, portanto - e depois em O Jornal do Rio de Janeiro em dezembro de 34, antes de ser incluído na segunda edição de Alguma poesia, de 1942. Único do livro escrito depois de 1930, o poema é uma espécie de recriação literária em prosa e verso da experiência de Drummond na Revolução de 30, da qual participou como funcionário das Forças Revolucionárias Mineiras, em Barbacena, Minas Gerais. Salvo erro, trata-se da primeira tentativa de fôlego do Autor de cantar o tempo presente - programa estéticopolítico que ocuparia cada vez mais espaço em sua obra e que culminaria em $A$ rosa do povo, de 1945, como se sabe. Silviano Santiago parece ter visto mais semelhanças do que diferenças entre o poema e a produção de Drummond da década de 40, pois em uma das notas apostas à correspondência deste com Mário de Andrade, aventou se "Outubro 1930" não teria sido publicado em Alguma poesia com o sentido de uma autocrítica ao individualismo exacerbado do livro ${ }^{102}$. E, no prefácio à mesma edição da correspondência, Santiago deu um passo além, afirmando que o poema teria sido incluído "como a querer provar o passado de militância tenentista do poeta"103. Já Iumna Maria Simon viu no poema, pelo contrário, "uma colagem mesclada de registros variados, escrita com galhofa, anticivismo e consciência da insignificância da história local, em clima bem diverso de $A$ rosa do povo"104. Qual a posição, por conseguinte, ocupada por “Outubro 1930" dentro do primeiro lirismo de Drummond? Ponto de virada ou, pelo contrário, prolongamento do individualismo característico do seu livro de estreia?

$$
\begin{aligned}
& \text { Suores misturados } \\
& \text { no silêncio noturno. } \\
& \text { O companheiro ronca. } \\
& \text { O ruído igual } \\
& \text { dos tiros e o silêncio }
\end{aligned}
$$

\footnotetext{
102 COELHO, Lélia (org.). Carlos \& Mário: correspondência completa entre Carlos Drummond de Andrade - inédita - e Mário de Andrade. Rio de Janeiro: Bem-Te-Vi, 2002, p. 398.

${ }^{103}$ Silviano Santiago, "Suas cartas, nossas cartas". In: Lélia Coelho (org.), op. cit., p. 30-31.

104 Iumna Maria Simon, "O mundo em chamas e o país inconcluso". In: Novos estudos. São Paulo: CEBRAP, 103, novembro 2015, p. 170.
} 
na sala onde os corpos

são coisas escuras.

O soldado deitado

pensando na morte. ${ }^{105}$

A abertura do poema surpreende porque, no lugar de lances espetaculares, próprios a um acontecimento histórico importante, focaliza detalhes insignificantes dos bastidores. A escolha por retratar suores e roncos sugere um ponto de vista inserido na situação, mas que não tem não acesso à sua totalidade, ou pelo menos, que não a compreende inteiramente. Essa impressão é reforçada pelo emprego de artigos definidos no lugar de indefinidos, opção que especifica os elementos da descrição, evitando generalizações. "Outubro 1930" vai, assim, na contramão das representações históricas oficiais, esquemáticas e repletas de patriotada, como se sabe. A primeira estrofe do poema é, ao invés, composta pela soma de descrições fragmentadas que compõem uma cena em que a voz poética está inserida, embora não de forma explícita. A perspectiva se constitui nela junto com a sucessão dos versos, em um processo de ajustamento do foco que parte do dado concreto microscópico no primeiro verso - os suores - até chegar ao mais abstrato no último - a morte, pensada pelo soldado. Quanto ao léxico, a primeira estrofe se caracteriza pelo predomínio de substantivos concretos e prosaicos. Já a pontuação é minguada e consiste em apenas quatro pontos finais. As orações resultantes não coincidem com os versos, que as fatiam com repetidos enjambements, produzindo unidades curtas e com tamanhos parecidos. $\mathrm{O}$ uso desses cortes também gera expectativas no leitor. Isso porque o desmembramento das orações interrompe o fluxo da leitura, sugerindo uma quebra, como se antecipasse uma virada repentina, que entretanto não ocorre. Dito de outro modo, a cada novo enjambement nos preparamos para ingressar no conflito propriamente dito, o que é frustrado pela persistência do distanciamento em relação aos eventos. A estrofe se mantém, em outras palavras, afastada e apenas observa os fatos a que se refere o título. "Outubro 1930" também joga com as expectativas do leitor através da sonoridade. Quer dizer, os versos armam uma confusão entre, de um lado, os ruídos e o silêncio e, de outro, o sono e a morte. Pois, do mesmo modo como o silêncio faz pensar tanto nos que dormem quanto nos mortos, os ruídos - sugeridos foneticamente pelos sons rascantes - podem ser tanto dos tiros quanto dos roncos. A

\footnotetext{
105 Carlos Drummond de Andrade, Poesia 1930-62. Organização: Júlio Castañon Guimarães. São Paulo: Cosac Naify, 2012, pp. 139-142.
} 
estrofe mistura, portanto, a dimensão banal - roncos e dorminhocos - à dimensão excepcional e bárbara - tiros e mortos - dos fatos, destituindo-os ao cabo de grandiosidade, o que já aponta para o pé-atrás de Drummond em relação aos acontecimentos que inspiraram o poema, pondo em xeque, por tabela, a militância tenentista imaginada por Silviano Santiago.

De 5 em 5 minutos um ciclista trazia ao Estado-Maior um feixe de telegramas contendo, comprimida, a trepidação dos setores. O radiotelegrafista ora triste ora alegre empunhava um papel que era a vitória ou a derrota. Nós descansávamos, jogados sobre poltronas, e abríamos para as notícias olhos que não viam, olhos que perguntavam. Às 3 da madrugada, pontualmente, recomeçava o tiroteio.

No lugar da segunda estrofe e fazendo as vezes dela, há um pequeno parágrafo em prosa. Junto com "O sobrevivente", "Outubro 1930" é o único poema de Alguma poesia em que prosa e verso se combinam. Porém, mesmo só aparecendo nesses dois poemas, é possível falar em um certo flerte do verso drummondiano deste período com a prosa. Isso porque sobretudo nos poemas mais longos de Alguma poesia - por exemplo, em "Explicação" - há uma tendência a extrapolar a autonomia dos versos em benefício do encadeamento do conjunto, como se o movimento poético procurasse extravasar a unidade rígida das suas partes, o que se explica em boa medida porque Drummond se formou fora da tradição do verso metrificado e em oposição a ela ${ }^{106}$. Nesse sentido, a mescla entre prosa e verso em "Outubro 1930" e, de modo mais amplo, a experimentação formal de Alguma poesia se inserem e dão continuidade à pesquisa estética empreendida pelo Modernismo desde o começo da década de 20. No caso específico de "Outubro 1930", a distensão do verso até a prosa poderia levar a pensar em uma conversão à épica, que nos acostumamos a vincular com a prosa e que talvez fosse mais afinada com o assunto, mas não é o que ocorre, até porque depois do parágrafo há outras estrofes em verso. $\mathrm{Na}$ verdade, essa mescla entre prosa e verso embaralha e tensiona os valores comumente relacionados com cada um e, indiretamente, com a épica e com a lírica, já que nos habituamos a associar o gênero ao emprego de uma ou outra forma. Tratava-se, assim, de redefinir a divisão estrita entre os gêneros, o que foi um dos anseios dos modernistas, em geral (basta lembrar de Macunaíma, de Mário de Andrade, ou de Serafim

${ }^{106}$ Cf. Antonio Candido, "A revolução de 30 e a cultura". In: A educação pela noite. Rio de Janeiro: Ouro sobre Azul, 2011, p. 239. 
Ponte Grande, de Oswald de Andrade), e de Drummond, em particular, haja vista o cunho prosaico do seu verso desse período. Essa tentativa de redefinir e borrar os limites entre os gêneros condensa uma das tensões essenciais de "Outubro 1930", qual seja: a que diz respeito às dificuldades de abordar um tema de proporções épicas através de uma perspectiva subjetiva e parcial. O poema explora, desse modo, não as diferenças e rupturas entre os gêneros, mas a articulação inesperada entre eles.

Esse esforço de alinhavar prosa e verso é perceptível na passagem da primeira estrofe para o parágrafo em prosa, pois este mantém o caráter descritivo daquela. Nele, a rotina no Estado-Maior é descrita. Longe de serem confusos, os eventos narrados obedecem surpreendentemente a uma organização rigorosa, com horários e intervalos bem definidos. Ou seja, mesmo em meio ao caos do conflito, os eventos se sucedem de maneira monótona e repetida. Daí o tédio que atravessa a estrofe e que nem mesmo a notícia mais importante - a vitória ou a derrota - é capaz de quebrar. A voz poética também aparece pela primeira vez no parágrafo. Na forma do pronome de primeira pessoa do plural, ela figura a si e aos companheiros que aguardam o desdobramento dos fatos. A opção pelo plural "nós" ao invés do singular "eu" sugere uma espécie de pertencimento coletivo, como se a escala ampliada dos acontecimentos anulasse as diferenças entre os participantes, igualando-os. Essa desdiferenciação é, no entanto, contrabalanceada pela especificação espacial da cena. Ao situar a ação no Estado-Maior, o parágrafo localiza e determina a extração dos aglutinados em torno do pronome "nós". Com isso, ele estabelece uma diferença interna entre os envolvidos, que se dividem entre soldados e funcionários. A voz poética se particulariza, portanto, como a de um funcionário, que está e não está dentro da situação, porque, se por um lado está inserido, por outro é apenas um espectador - aliás, entediado - que acompanha as novidades via telégrafo. Salvo erro, em "Outubro 1930" é a primeira vez que um ponto de vista interno e participante surge na obra de Drummond, o que não deixa de ser um sinal de que nosso Autor estava dando continuidade à experimentação instituída pelo Modernismo quando da redação do poema e, mais ainda, de que estava tentando abrir novos rumos poéticos, como também veremos a partir da análise das cartas que enviou nesse período a Mário de Andrade. Por sua vez, a oscilação intrínseca à condição de funcionário entre participar e só observar - atitude esta recorrente em Alguma poesia, como se sabe - é sinal das dificuldades enfrentadas pelo poeta mineiro para trilhar novos caminhos. Essa oscilação pode ser interpretada, enfim, no sentido tanto de uma tentativa de renovação (que era também, e sobretudo, um 
princípio modernista, a que o poema atualizava desse modo), quanto de uma insatisfação do poeta com o lirismo do seu primeiro livro, o que vai ficar mais claro na segunda parte, quando discutirmos a correspondência de Drummond do período.

$$
\begin{aligned}
& \text { O funcionário deitado } \\
& \text { não pensa na morte. } \\
& \text { Pensa no amor } \\
& \text { tornado impossível } \\
& \text { no minuto guerreiro. } \\
& \text { E fecha os olhos } \\
& \text { para ver bem } \\
& \text { o amor com sua espada } \\
& \text { de fogo sobre a cabeça } \\
& \text { de todos os homens, } \\
& \text { legalistas, rebeldes. }
\end{aligned}
$$

A estrofe se organiza a partir das diferenças entre o soldado e o funcionário, pois, enquanto o primeiro pensa na morte, o segundo pensa no amor. Essa diferença se explica pela função e, mais especificamente, pela posição de cada um em relação ao front. A salvo dos tiros (que na primeira estrofe confundia com roncos), o funcionário não precisa se preocupar com a morte, como o soldado, e pode pensar no amor, frustrado pelos acontecimentos. Formalmente, a diferença entre eles é construída a partir de uma semelhança. A repetição do verbo "deitado" sugere a identificação entre ambos, porém é desfeita no verso seguinte pela negativa "não pensa na morte". Ou seja, o enjambement do primeiro verso cria expectativas para logo em seguida desmanchá-las. Já a opção pelo artigo definido aproxima da voz poética tanto o soldado quanto o funcionário. Na verdade, o funcionário em questão parece ser a própria voz poética se referindo a si mesma. A referência a si na terceira pessoa é razoavelmente comum ao longo da obra de Drummond e está presente em Alguma poesia no "Poema de sete faces" e em "Nota social". No caso de "Outubro 1930", a confusão entre a primeira e a terceira pessoa permite uma mudança brusca do foco, que logra acessar desde o que se passa na cabeça dos participantes até as notícias das cidades mais remotas do país, como veremos a propósito da última estrofe. O poema pode correr assim em dois planos distintos - o subjetivo e o objetivo - sem quebra do registro, o qual oscila livremente entre verso e prosa, épica e lírica, primeira e terceira pessoas etc. Essa dubiedade do ponto de vista como que antecipa o recurso 
chamado por José Guilherme Merquior de "personificação do eu"107, que é recorrente no segundo livro de Drummond, Brejo das Almas, de 1934, e que consiste na cisão efetiva da subjetividade e na projeção da interioridade como alteridade. A presença desse recurso em "Outubro 1930" pode ser lida, em suma, como uma espécie de elo entre os dois primeiros livros do poeta mineiro. Nesse sentido, o poema constitui algo como uma ponte entre os dois, já que nele os temas e procedimentos mais típicos de Alguma poesia convivem com o caráter problemático dos poemas de Brejo das Almas. Ou por outra, nas polaridades que sustentam e entre as quais oscila "Outubro 1930", já se anuncia a indecisão que caracteriza o livro de 1934.

Essa polaridade é encarnada, no poema, pelo ponto de vista. Ao aderir à perspectiva do funcionário, a voz poética ocupa uma posição dupla de participante e de espectador, o que, além de um dado autobiográfico, é um achado estético. Porque, se é interno aos acontecimentos, aos quais descreve de dentro, o ponto de vista do funcionário é externo em comparação com o do soldado, que está colado, e em relação ao combate propriamente dito, ao qual apenas assiste. A distinção entre funcionário e soldado esmiuçada na estrofe especifica, assim, o foco do poema. O resultado é uma voz poética dúplice, que mistura um Eu lírico tradicional, cuja subjetividade se confunde com a objetividade, com um Narrador prototípico que dispõe epicamente do seu assunto. Essas categorias são, no entanto, redimensionadas e rebaixadas pelo cunho banal e desimportante atribuído pelo próprio poema aos eventos abordados, o que gera um efeito derrisório. Quer dizer, a mescla entre épica e lírica em "Outubro 1930" ressalta o comezinho da situação, espelhando sua falta de sentido com o anti-heroísmo do indivíduo. Isso fica claro na terceira estrofe, onde a voz poética figura a si na terceira pessoa devaneando sobre o obstáculo representado pelos fatos para a concretização do amor. Protegida dentro do Estado-Maior e alheia ao terror dos tiroteios, ela vê o amor com sua espada de fogo pairar acima de legalistas e rebeldes. $\mathrm{O}$ devaneio - o amor como algo mais poderoso e terrível do que o conflito - atesta o egoísmo e a ausência de solidariedade, contrariando a sugestão de coletividade expressa no pronome "nós" do parágrafo anterior. Portanto, a estrofe contradiz o parágrafo que a sucedeu e arma uma tensão entre indivíduo e coletivo, com o qual o eu lírico ora se identifica ora repele. Nessa medida, "Outubro 1930" se distingue profundamente de A rosa do povo, como bem viu Iumna Maria Simon.

${ }^{107}$ Cf. José Guilherme Merquior, Verso Universo em Drummond. Rio de Janeiro: José Olympio, 1968, pp. $35 \mathrm{ss}$. 
No livro de 1945, a saturação sintática e rítmica do verso de elementos da prosa impulsionava - como demonstrou Iumna - um programa politizado e coletivista que pretendia romper com a literatice da poesia ${ }^{108}$. Tratava-se, desse modo, de internalizar na construção do verso seus limites e insuficiências, questionando-o pela raiz. Já em "Outubro 1930", pelo contrário, a permeabilidade entre prosa e verso trai a posição ambígua da voz poética em relação a Revolução de 30, da qual desconfiava.

O inimigo resistia sempre e foi preciso cortar a água do quartel. Como resistisse ainda, a água circulou de novo, desta vez azul, de metileno. A torneira aberta escorre desinfetante. O canhão fabricado em Minas suave temperamento local - não disparou.

O foco sofre uma mudança abrupta na passagem da estrofe para o parágrafo. Ao invés de se deter na imaginação do funcionário, ele se volta para um episódio mais amplo. A mudança súbita dos devaneios para a narração da manobra militar não acarreta, porém, quebra ou ruptura no andamento do poema, porque a voz poética fantasiosa também está presente no parágrafo, ainda que não de forma explícita, e deixa sua marca nele, mais especificamente na caracterização do canhão, "suave temperamento local". Essa caracterização rompe com o caráter objetivo do parágrafo e o vira de ponta-cabeça retroativamente, pois explicita o teor absurdo do que é narrado. A seriedade do parágrafo é, em outras palavras, deslocada pelo prisma irônico que desponta na última oração e que desvela o disparate da narração. A caracterização fantasiosa do final também revela, desse modo, o distanciamento da voz poética em relação aos eventos narrados, aos quais não adere e, pelo contrário, ridiculariza através da ironia. Como na estrofe anterior, portanto, o grão de fantasia do parágrafo configura o retraimento de um indivíduo que faz parte dos fatos, mas que não se identifica com eles. Ou por outra, a predominância de detalhes e de aspectos sem importância, somada à tendência a devanear, possibilitam a estruturação de

\footnotetext{
108 "Hoje é quase impossível avaliar o quanto o verso - "A poesia fugiu dos livros, agora está nos jornais" impulsionava um programa antiliterário e demandava da efusão lírica, da expressão polida, do verso bem torneado, mas fechado ao contemporâneo, uma inspiração autenticamente antielitista, politizada e coletivista, aberta à atualidade da vida - um programa de vanguarda, seja dito. Drummond representou àquela altura a expressão por excelência da crise do verso (que vai ser saturado de prosa, sintática e ritmicamente), o reconhecimento de certo arcaísmo da literatura e da poesia, como se então precisasse buscar fora das duas o que é mais necessário e urgente para atualizar a experiência da poesia. É sob a perspectiva angustiada e autocrítica do processo comunicativo que $A$ rosa do povo apresenta eu, amor e poesia como instâncias históricas, desfiguradas pela sociedade burguesa e brasileira, suscetíveis no entanto de reforma e transformação". Iumna Maria Simon, "O mundo em chamas e o país inconcluso", cit., p. 176.
} 
um prisma que mensura a Revolução de 30 a partir da própria subjetividade. Logo, a inovação representada por "Outubro 1930" dentro do primeiro lirismo de Drummond é, por um lado, significativa, pois desloca o indivíduo do ponto externo em que ele se postava na maioria dos poemas de Alguma poesia para dentro da situação; por outro, porém, ela não deixa de ser limitada, porque, apesar de estar inserida, a voz poética não se engaja e, ao invés, representa os acontecimentos com circunspecção e ironia, em um espírito muito semelhante ao de outros poemas do livro de 1930, como por exemplo "A rua diferente" e, sobretudo, "Moça e Soldado". O poema ocupa, por isso, uma posição intermediária e, como tal, estratégica dentro do percurso poético do poeta mineiro, pois nele vislumbramos simultaneamente uma tentativa de mudança e uma conservação dos tópicos do seu primeiro livro. O arranjo dessas disposições contraditórias entre si gera uma espécie de solução de compromisso, dentro da qual os procedimentos e, especialmente, o ímpeto de atualização da produção de Drummond da década de 20 convivem com as inovações que amadureceriam em seus livros publicados a partir de 1930 e, em especial, de 1940. De modo mais amplo, esse esforço por conciliar posições antagônicas está no âmago - como estamos tentando argumentar neste trabalho - da poética e do desdobramento da sua obra, que se deu pelo embate e pela superação imanente, de onde aliás a coerência rigorosa da sua trajetória lírica.

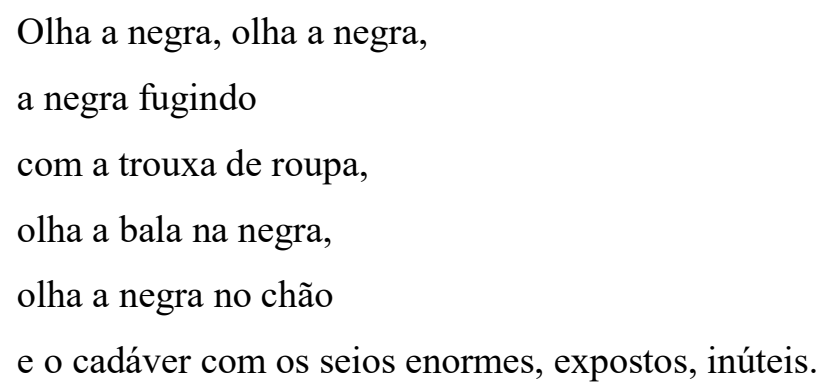

A repetição do verbo "olhar" evidencia a condição de mera observadora da voz poética na estrofe. Já a escolha da forma do imperativo afirmativo sugere a presença de um interlocutor (que, por enquanto, não sabemos quem é), como se se dirigisse a ele para convocá-lo a observar a cena. Ou seja, separado por uma distância segura dos eventos que narra, a voz poética impele o seu leitor a encarar a morte inútil e, por isso, muito mais trágica da negra. A estrofe pode ser lida, nesse sentido, como uma espécie de denúncia enviesada da violência dos acontecimentos. Esse caráter de denúncia é potencializado pelo uso de pronomes definidos para especificar os substantivos, o que particulariza a vítima, ressaltando sua humanidade e impedindo que ela se transforme em um número ou 
abstração. Por meio da narração de um fato concreto, portanto, a estrofe investe contra a grandiosidade do evento, dentro do qual o indivíduo perde sua individualidade e se dissolve. Desse modo, ela repõe e reconfigura a tensão estrutural do poema entre o particular e o universal. Além disso, a estrofe rompe com o teor irônico do parágrafo anterior, porque explora a dimensão trágica e violenta, a qual só aparecera até então de relance e em chave irônica na confusão armada na primeira estrofe entre tiros e roncos. Essa mudança também se expressa na variação de tom em relação ao resto do poema, porque, diferentemente das outras partes, a estrofe é trágica e destituída de ironia. A ruptura promovida na estrofe é importante dentro do conjunto, na medida em que explicita a fragmentação do poema, cujo princípio de construção é justamente essa variação de foco e de registros diversos. No caso específico da estrofe, a opção pelo registro literal parece corresponder a um certo aturdimento da voz poética, como se esta não entendesse muito bem a violência à sua volta. Quer dizer, o aspecto tosco dos versos - cujo vocabulário é pobre, além de repetitivo, e onde não há conjunções ou subordinação entre as orações - configura literariamente a atonia e a impotência da voz poética diante de fatos que não consegue compreender muito bem por estar inserido neles, o que impede que tenha uma visão global do todo. O ponto de vista parcial e fragmentário acaba formulando, assim, uma visão profundamente negativa que está muito distante de qualquer tipo de idealização.

O general, com seus bigodes tumultuosos, era o mais doce dos seres, e destilava uma ternura vaporosa em seu costume de usar culotte sem perneiras. A um canto do salão atulhado de mapas e em que telefones esticados retiniam trazendo fatos, levando ordens, eu fazia, exercício fácil, a caricatura do seu imenso nariz. Que todos achavam ótima e reprovavam com indignação.

O parágrafo rompe com o caráter trágico da estrofe anterior e instaura um novo tom, engraçado e galhofeiro. Como nas primeiras partes, sobretudo nos parágrafos anteriores, a verve satírica se revela a propósito das situações vividas, como se os dados concretos e, de modo mais amplo, o curso absurdo dos fatos acendessem e estimulassem a imaginação fértil da voz poética. No parágrafo, o elemento fantasioso irrompe na forma de adjetivos ("tumultuosos", "doce", "vaporosa") inusitados que destoam da situação banal por eles predicada. Como em outros poemas de Alguma poesia (por exemplo, em “Jardim da Praça da Liberdade", como vimos), portanto, a imaginação reponta de maneira 
inesperada e sugere obliquamente o distanciamento do eu lírico em relação ao que descreve. No caso de "Outubro 1930", a aparição desses adjetivos está ligada ao tédio e à reserva da voz poética diante dos eventos de que participa. O efeito dessa aparição é cômico, porque esses elementos estabelecem um abismo inesperado entre a realidade prosaica e burocrática e a representação escarninha. O poema se assemelha, nesse sentido, à caricatura do nariz do general, pois resulta como esta em uma distorção do dado imediato cujo resultado é engraçado, além de anticívico. Porém, é preciso frisar que, tanto em "Jardim da Praça da Liberdade" quanto em "Outubro 1930", o abismo existente entre a representação e a realidade não decorre de um prisma exógeno, mas, pelo contrário, de um endógeno, que cria uma inserção tensa. E de fato, nos dois poemas a perspectiva está como que dentro, mas deseja se diferenciar do meio que a entedia e do qual escarnece como uma espécie de compensação imaginária. E, por mais que o desejo de se diferenciar possua em última análise um fundo dramático por causa da dificuldade de individuação que expressa, o distanciamento resultante desse desejo se reveste na maior parte dos poemas de Alguma poesia de um aspecto divertido, à maneira da descrição meio banal meio fantástica de "Jardim da Praça da Liberdade" e dos parágrafos em prosa de "Outubro 1930", onde é ainda mais surpreendente porque empregado a propósito de um conhecido episódio da história nacional, que poderia parecer infenso ao tratamento humorístico.

Mário de Andrade notou um distanciamento semelhante nos poemas de Alguma poesia. Em "A poesia em 1930", Mário identificou o por ele chamado de "sequestro da vida besta", isto é, a "vontade íntima de aniquilar, de se esconder"109 oriunda da inadequação de Drummond diante da vida. Ou seja, reverberando a intensa agitação ideológica que caracterizaria o debate intelectual da década de 30, Mário problematizava o individualismo do poeta mineiro por estar em desacordo com as

exigências da vida social contemporânea que já vai atingindo o Brasil das capitais, o ser socializado, de ação muita, eficaz pra sociedade, mais público que íntimo, com maior raio de ação que o cumprimento do dever na família e no empreguinho ${ }^{110}$.

E concluía: "o poeta adquiriu uma consciência penosa da sua inutilidade pessoal e da inutilidade social e humana da "vida besta"" - como procuraremos mostrar mais à frente, essas palavras calaram fundo no poeta mineiro e foram decisivas para disparar o processo de renovação em que “Outubro 1930” se inscreve. Por agora, importa reter que Mário

\footnotetext{
${ }^{109}$ Mário de Andrade, Aspectos da literatura brasileira. São Paulo: Editora Martins, 1974, p. 33.

${ }^{110}$ Id., ibid., p. 36.
} 
associava, em linhas gerais, essa vontade íntima de se esconder ao uso, de um lado, da metrificação e, de outro, de "movimentos ostensivamente cancioneiros e aparentemente alegres e cômicos". Quer dizer, o autor de Macunaíma interpretava o emprego desses recursos como uma reação (ou sublimação, como também designava) de Drummond contra sua inenarrável capacidade para viver. Esse processo é exemplificado com "A balada do amor através das idades", que para Mário era o "clímax do sequestro" pois nele o poeta se vinga da vida besta, botando miríficos suicídios e martírios estrondosos em casos de amor de diferentes épocas passadas. Menos na contemporânea, em que faz o amor dar em casamento, em burguesice, em... vida besta: é ele. ${ }^{111}$

Ou seja, o presente em que o eu lírico está inserido é representado de um ângulo inferiorizado em relação às demais épocas retratadas no poema. Guardadas as diferenças, em "Outubro 1930" ocorre algo semelhante. Pois nele a voz poética se compraz outrossim em avacalhar os sucessos vividos, como se lastreasse liricamente os fatos de amplitude épica a partir de sua experiência pessoal.

A esta hora no Recife,

em Guaxupé, Turvo, Jaguara,

Itararé,

Baixo Guandu,

Igarapava

Chiador,

homens estão se matando

com as necessárias cautelas.

Pelo Brasil inteiro há tiros, granadas,

literatura explosiva de boletins,

mulheres carinhosas cosendo fardas

com bolsos onde estudantes guardarão retratos

das respectivas, longínquas namoradas,

homens preparando discursos,

outros, solertes, captando rádios,

minando pontes,

outros (são governadores) dando o fora,

pedidos de comissionamento

por atos de bravura,

${ }^{111}$ Id., Ibid., p. 36 
ordens do dia,

"o inimigo (?) retirou-se em fuga precipitada,

deixando abundante material bélico,

cinco mortos e vinte feridos..."

Um novo, claro Brasil

surge, indeciso, da pólvora.

Meu Deus, tomai conta de nós.

Deus vela o sono dos brasileiros.

Anjos alvíssimos espreitam

a hora de apagar a luz de teu quarto

para abrirem sobre ti as asas

que afugentam os maus espíritos

e purificam os sonhos.

Deus vela o sono e o sonho dos brasileiros.

Mas eles acordam e brigam de novo.

Diversamente do resto do poema, as últimas estrofes ensaiam abandonar a perspectiva parcial para dar conta do episódio em sua totalidade. Isto é feito por meio de uma troca no ponto de vista. $\mathrm{O}$ foco parcial é substituído na estrofe por um mais amplo. Com a mudança, os fatos são reescalonados e assumem uma nova dimensão - nacional, por assim dizer - que ao mesmo tempo contém e supera o ponto de vista parcial. Essa mudança é antecipada pelo sobrevoo enumerativo dos primeiros versos, onde o noticiário das cidades e dos rincões mais remotos é incorporado. Os versos adquirem, por isso, a aparência de manchetes: "a esta hora no Recife", "homens estão se matando" e "pelo Brasil inteiro há tiros, granadas". É sabido que o despojamento da linguagem jornalística exerceu forte atração sobre os modernistas, em geral (sem dúvida, o exemplo mais emblemático é o arquifamoso "Poema tirado de uma notícia de jornal", de Manuel Bandeira), e sobre Drummond, em particular. No caso do poeta mineiro, a relação com o jornalismo foi bastante estreita, até porque ele trabalhou na imprensa belorizontina ao longo das décadas de 20 e 30, além de ter colaborado praticamente a vida inteira em jornais e periódicos. Essa vivência se reflete em seu livro de estreia no "Poema do jornal", que tematiza o ritmo mecânico da fabricação de notícias (a assim chamada "doce música mecânica"), e na "Anedota búlgara", que glosa uma curiosa notícia da época. Como nos dois poemas, em "Outubro 1930" o aproveitamento do estilo jornalístico é irônico, porque 
a aparência de notícia dos seus versos é transformada na sequência. Quer dizer, a primeira parte das orações - seccionada pelos enjambements, que preparam a surpresa - é alterada pela continuação. Assim, por exemplo: nos versos: "homens estão se matando/com a necessária cautela", a escolha do substantivo "cautela" depois da matança sugerida pelo plural "estão se matando" cria uma espécie de curto-circuito semântico, por causa da desproporcionalidade dos termos, deslocando a ênfase do terror das mortes para o absurdo cômico da situação. Trata-se de uma estratégia - por sinal, recorrente em toda a obra de Drummond - por meio da qual o tema apresentado no começo é retrabalhado por outros ângulos ao longo do poema, o que dá a este um teor prismático. Como estamos vendo, em "Outubro 1930" essa variação está ligada à troca da objetividade inicial por uma visão mediada e pessoalíssima dos fatos. O efeito lírico do poema como que depende em suma dessa intromissão da subjetividade, que imanta sua matéria com uma carga nova e inesperada.

Essa tensão entre subjetividade e objetividade atravessa e estrutura as últimas estrofes. Ela está cifrada, por exemplo, no emprego do pronome pessoal "nós" para representar a voz poética. Isso porque, como em outros momentos do poema, o pronome no plural sugere uma coletividade entre os participantes que é desmentida pelos acontecimentos narrados, em que cada um cuida dos seus próprios interesses. Trata-se, assim, de um uso irônico que ressalta a ausência de solidariedade entre funcionários, soldados e governadores. As estrofes finais armam por meio disso uma espécie de jogo entre identificação e estranhamento, como se a dimensão monumental dos fatos ameaçasse apagar a identidade dos participantes. Esse jogo se exprime no verso "o inimigo (?) retirou-se em fuga precipitada", pois o ponto de interrogação entre parêntesis questiona a identificação imposta pelos fatos, insinuando que ela é incapaz de definir os envolvidos individualmente. Esse jogo também está presente no emprego do plural "brasileiros" como uma categoria capaz de subsumir os envolvidos. A sequência da estrofe indica, inversamente, que, apesar de terem nascido no mesmo país, os envolvidos não se identificam sob nenhum outro aspecto, tanto que só estão preocupados em salvar a própria pele. A generalidade abstrata de categorias como "nós", "inimigo" e "brasileiros" é, por conseguinte, tensionada ao máximo e esfacelada nas estrofes finais, onde os interesses envolvidos se revelam completamente divorciados uns dos outros e onde vigora um clima de salve-se quem puder. Ao contrário do que se poderia imaginar, porém, o tom dessas estrofes não é dramático ou sombrio, mas mordaz e satírico, pois 
nelas o acento recai sobre o lado cômico da barafunda resultante, e não sobre o lado trágico. As tensões exploradas nas últimas estrofes em torno da individualidade e da sua irredutibilidade em relação ao coletivo podem ser interpretadas em mais de um sentido. Por um lado, elas entroncam e traduzem o individualismo característico da produção poética de Drummond da década de 20 (mas que nem nos momentos de maior engajamento foi abandonado). Por outro lado, todavia, a exploração dessas tensões conflui com a trajetória lírica posterior do poeta mineiro e, em especial, com o progressivo escrutínio a que o seu próprio individualismo foi submetido sobretudo a partir de Brejo das almas, de 1934. "Outubro 1930" pode ser lido, então, como um prenúncio tímido da reavaliação problemática e angustiada por que passou o egotismo profundo do Autor em seus escritos das décadas de 30 e, principalmente, de 40 .

Na última estrofe do poema, destaca-se a quantidade de termos religiosos. Com efeito, em apenas oito versos se concentram expressões como "Deus vela", "anjos alvíssimos", "asas", "maus espíritos", "purificam" e novamente "Deus vela". A presença dessas expressões surpreende porque são invocadas a propósito de uma situação que o restante do poema já desqualificara como banal e ridícula, atrelada aos interesses mais díspares e da mais completa imanência. Mas é interessante notar que, contrariando as expectativas, a existência de termos oriundos do universo religioso é relativamente comum ao longo de Alguma poesia, onde estão espalhados em pouco menos de um quinto dos poemas do conjunto, entre eles o de abertura, o célebre "Poema de sete faces", e o de fechamento, "Poema da purificação". Em geral, a ocorrência desses termos é inesperada, porque eles despontam em contextos insólitos. No "Poema de sete faces", por exemplo, a abundância de referências religiosas, as quais estão inscritas no mais íntimo da estrutura do poema (por sinal, publicado pela primeira vez em pleno natal, no dia 25 de dezembro de 1928), resulta em uma combinação inusitada e original, pois nele os elementos sagrados (o auto natalino, as citações bíblicas) convivem com os blasfêmicos ("anjo torto", sombra) para compor uma certidão do Poeta e de sua personalidade poética gauche $^{112}$. Já em "Outubro 1930", essas referências são motivadas pelos acontecimentos e estão intrinsecamente ligadas ao contexto, na medida em que traduzem a impotência e a condição de mera espectadora da voz poética. Trata-se, em outras palavras, de um apelo desesperançado, fruto da incredulidade de os envolvidos acharem uma solução. E, com

112 Cf. Ivan Marques, Cenas de um modernismo de província: Drummond e outros rapazes de Belo Horizonte. São Paulo: Editora 34, 2011, p. 57. 
esses apelos, a voz poética acaba se colocando em uma posição de impotência e passividade em relação aos fatos, dos quais participa sem poder transformá-los. As invocações da estrofe lembram, por isso, as interjeições meio mecânicas meio resignadas da religiosidade popular, porquanto não formam sistema entre si e se assemelham a uma forma de pensamento mágico. Na verdade, boa parte das ocorrências de termos religiosos no primeiro livro de Drummond tem esse sentido popular e informal, como uma espécie de lugar comum, prosaico e corriqueiro, do português falado no Brasil. A articulação entre a busca de uma língua nacional (e, por metonímia, da própria nação) e o vocabulário religioso é, aliás, explicitamente tematizada em "Explicação", onde uma das funções do verso do eu lírico é justamente "louvar a Deus". De certo modo, portanto, o emprego desses termos estabelece um vínculo entre o indivíduo e os demais brasileiros, os quais se põem destarte em uma posição de menoridade que se satisfaz - para citar de novo "Explicação" - em meter a língua no governo e em acreditar que no fim dá tudo certo. No caso de "Outubro 1930", esse vínculo é delicado porque diz respeito à relação conflituosa entre a voz poética e o coletivo, do qual o indivíduo faz parte mesmo não podendo ser reduzido a uma categoria abstrata.

Na última estrofe, surgem dois pronomes da segunda pessoa do singular: o possessivo "teu" e o oblíquo "ti". O interlocutor pressuposto por eles não é, contudo, definido na estrofe ou antes dela, de sorte que só podemos conjecturar a respeito. Seja como for, penso que esses pronomes se dirigem à namorada distante da voz poética, por causa das diversas referências ao amor lançadas ao longo do poema - o que, a se confirmar, esclarece o mistério acerca da identidade do interlocutor da terceira estrofe. Em abono a essa hipótese, vale lembrar que na segunda estrofe em versos o funcionário deitado (que, segundo nossa interpretação, é a própria voz poética figurando a si mesma na terceira pessoa) pensa no "amor/ tornado impossível/ no minuto guerreiro"; que na terceira o verbo "olhar" na forma do imperativo implica a presença de um interlocutor; e, por fim, que na penúltima as "mulheres carinhosas cosendo fardas" e as "longínquas namoradas" podem incluir a namorada do funcionário. Já a impressão de separação existente entre a voz poética e sua amada está contida nessas referências, sobretudo no adjetivo "longínquas". Segundo nossa hipótese, portanto, a voz poética se encontra no Estado Maior, servindo como funcionário e separado da sua namorada, na qual pensa em meio aos acontecimentos e para a qual escreve. A ser assim, o poema ganha uma dimensão insuspeita: a de uma carta de guerra, de um balanço escrito à noite (haja vista 
as referências ao sono, à "hora de apagar a luz" e ao sonho) para dar notícias e relatar os episódios vividos por ela, voz poética. O mosaico composto pela mescla de registros distintos representa, em suma, uma tentativa de dar forma literária à sua experiência e participação na Revolução de 30. Através desse enfoque dinâmico e poliédrico, "Outubro 1930" se contrapõe ao tratamento estático e plano do realismo tradicional para formular um modo pessoal de recriar os eventos. E de fato, o poema configura uma espécie de transrealismo ${ }^{113}$ em que a visão da realidade é construída a partir da síntese de detalhes e pormenores acumulados ao longo do poema, compondo ao cabo um quadro bastante vivo dos fatos vividos.

Em janeiro de 1931, em um momento muito próximo ao da redação de "Outubro 1930", Drummond escreve em carta a Mário:

eu confesso que não consigo evadir-me do meu individualismo para vogar nessas paragens largas e povoadas para as quais me solicitam as tendências intelectuais do meu tempo, e por outro lado ainda não cheguei (e chegarei algum dia?) à maturação necessária para tentar a solução supra-realista, única que me parece aceitável para o meu caso, como de resto para todos os casos. E confesso mais, não sem tristeza, que a minha prisão individualista é tanto mais lamentável quanto me força eternamente aos mesmos exercícios poéticos, à eterna repetição de temas morais que constituem o tecido inalterável de minha vida, e que por fim devem aporrinhar o leitor, que diabo! Tanto mais que me aporrinham a mim próprio como você sabe perfeitamente. E isso é tão exato que os versos que venho compondo depois da publicação do meu livro (sempre entendi que um livro deve marcar uma fase encerrada na vida de um cidadão) não me parecem dizer nada de novo, o essencial já estando dito no livro. Preciso, pois, de abrir o meu caminho, e você sabe como isso representa uma tentativa difícil para mim. ${ }^{114}$

O poeta mineiro confessa na carta o desânimo que se abatera sobre ele depois da publicação de seu primeiro livro, Alguma poesia, de 1930. Já pela escolha das palavras

\footnotetext{
${ }^{113} \mathrm{O}$ termo é de Antonio Candido. Cf. São Paulo: Companhia das Letras, 1993, p. 125.

"Realidade e realismo (via Marcel Proust)", in: , Recortes. ${ }^{114}$ Lélia Coelho (org.), op. cit., pp. 401-402.
} 
("tristeza", "prisão", "lamentável"), fica claro que não se tratava de um mero bloqueio artístico ou algo do gênero, mas de uma crise de espectro bem mais largo e profundo. $\mathrm{Na}$ verdade, o sentimento descrito era tanto mais angustiante na medida em que, quando escreveu a carta, Drummond atinara com sua razão - a incapacidade para evadir-se da prisão individualista -, mas ainda não vislumbrara uma solução, ou melhor, a única solução enxergada - o assim chamado "supra-realismo" - não estava ao seu alcance, por não ter ele atingido ainda a "maturação necessária". E esse sentimento era complexo porque possuía uma dimensão dupla: do lado mais superficial, era poético e artístico, porque dizia respeito às dificuldades do Autor para produzir algo distinto do individualismo característico dos poemas do seu livro de estreia; no fundo, porém, ele era moral e ideológico, porque decorria do seu alheamento em relação às tendências intelectuais do seu tempo que o solicitavam. Tratava-se, assim, de uma crise que se expressava na incapacidade para criar, mas cuja origem era outra, de raiz ideológica. $\mathrm{O}$ âmbito estético se cruzava naquele momento com o ideológico e gerava uma situação aporética, que obrigava o poeta mineiro a girar em círculo, isto é, a repetir os mesmos velhos "temas morais".

Na verdade, a carta do poeta mineiro era uma resposta franca e direta a uma crônica de Mário de Andrade publicada em junho de 1930 no Diário Nacional. Em "Puro, sem mistura", Mário comentava a publicação de Alguma poesia, de Drummond, e de Libertinagem, de Manuel Bandeira, e assinalava a pureza psicológica deles, os quais, a despeito da "impressionante exposição de alma humana", eram a seu ver eminentemente individualistas. E advertia:

minha impressão é que isso é um beco sem saída. Está claro que a gente pode morar no beco a vida inteira porém será concebível o beco na civilização urbanista Le Corbusier? Sempre é certo que há dois jeitos da gente sair do beco. Um é simples como beber água: sair por onde se entrou, trair-se. E trair o conceito metafórico que todos nós temos de beco sem saída. O outro meio será talvez mais propício a essas duas almas livres: botar dinamite nas casas e se evadir do indivíduo pra mais puros longes ainda - o automatismo psíquico do sobre-realismo. ${ }^{115}$

\footnotetext{
115 Mário de Andrade, "Puro, sem mistura". In: Táxi e crônicas no Diário Nacional. Estabelecimento de texto, introdução e notas Telê Porto Ancona. São Paulo: Livraria Duas Cidades; Secretaria de Cultura, Ciência e Tecnologia, 1976, p. 213.
} 
Além de apontar o impasse - "o beco na civilização urbanista Le Corbusier" -, Mário sugeria saídas: ou trair-se, isto é, abandonar o individualismo contra a própria natureza, ou aprofundá-lo através do automatismo psíquico do sobre-realismo, opção que considerava mais propícia e que Drummond aceitou, embora confessasse na carta sua incapacidade para colocá-la em prática. Portanto, a crônica (mas não só: o ensaio "A poesia em 1930" também foi importantíssimo, pois batia na mesma tecla, como vimos) foi ao encontro do descontentamento difuso do poeta mineiro, que até então não sabia formular a origem desse sentimento, precipitando o tom crítico e até culpado com que Drummond passa a encarar a própria posição a partir deste momento. É provavelmente a esse processo que nosso Autor iria se referir em um depoimento de 1938 (e depois incluído em Confissões de Minas) como a "consciência crescente da sua precariedade e uma desaprovação tácita da conduta (ou falta de conduta) espiritual do autor"116. A advertência de Mário contribuiu, em resumo, para catalisar o exame crítico do lirismo de Alguma poesia que nosso Autor já vinha ruminando - inclusive poeticamente, como o demonstra "Outubro 1930" -, mas com cujas razões não atinara até digamos o começo de 1931. Iniciava-se, assim, um movimento íntimo de questionamentos e tomada de consciência, repleto de tateios e dúvidas, como estamos vendo, e que se traduziu neste momento na consciência da precariedade dos temas do seu lirismo - desacompanhado, todavia, da superação correspondente, no caso a opção por uma das tendências intelectuais que o solicitavam.

De modo mais amplo, o processo descrito na carta se inseria na intensa movimentação ideológica do pós-Revolução de 30. No ensaio "A revolução de 30 e a cultura", Antonio Candido identificou o fenômeno da

surpreendente tomada de consciência ideológica de intelectuais e artistas, numa radicalização que antes era quase inexistente. Os anos de 1930 foram de engajamento político, religioso e social no campo da cultura. Mesmo os que não se definiam explicitamente, e até os que não tinham consciência clara do fato, manifestaram na sua obra esse tipo de inserção ideológica, que dá contorno especial à fisionomia do período $^{117}$.

\footnotetext{
${ }^{116}$ Carlos Drummond de Andrade, "Autobiografia para uma revista". In: Confissões de Minas. São Paulo: Cosac Naify, 2011, pp. 68.

${ }^{117}$ Antonio Candido, "A revolução de 30 e a cultura", cit., p. 220.
} 
A carta pode ser lida, então, como uma espécie de testemunho de que Drummond absorveu e repercutiu a intensa movimentação ideológica que agitou nossa intelectualidade ao longo da década de 30. É claro, por outro lado, que a despeito dessa afinidade, falar em engajamento ou militância a propósito da produção de Drummond do começo da década de 30 não deixa de ser descabido - e "Outubro 1930" o prova -, pois, como vimos, nosso Autor estava às voltas com impasses e dificuldades, mas não ainda com um caminho a seguir - o qual só se manifestaria com mais clareza em sua produção poética da década de 40, como hoje sabemos. Seja como for, o processo do qual resultou "Outubro 1930" é interessante, porque revela traços marcantes do seu pensamento poético, em particular o questionamento angustiado sobre o alcance e os limites do seu lirismo - questionamento que, sem prejuízo das enormes diferenças existentes, reaparecerá em diversos poemas de $A$ rosa do povo, o que não deixa de ser um ponto em comum entre momentos de resto tão distintos.

Em "Outubro 1930", a crise resultante do cruzamento das preocupações e ideológicas e estéticas se expressa no esforço para abrir novos caminhos. E de fato, o princípio de construção do poema é justamente a oscilação entre registros distintos, como se o Autor não conseguisse se decidir entre verso e prosa, épica e lírica, ponto de vista interno e externo, primeira e terceira pessoas, e os mesclasse em um movimento incessante que os tensiona reciprocamente. Essa oscilação pode ser lida como a expressão da inexistência de uma solução para os dilemas que inquietavam o poeta mineiro naquele momento porque, se está por trás da tentativa de trilhar novos rumos, também atesta o fracasso em se decidir por algum deles. Mais do que recursos artísticos, portanto, essas ambivalências formais traduzem a crise ideológica mais ampla por que então passava o poeta e que ainda se estenderia por alguns anos, até pelo menos a publicação de seu segundo livro, Brejo das almas, onde a indecisão prefigurada em "Outubro 1930" se converte no fracassismo difuso pelos poemas do livro de $1934^{118}$. Dito de outro modo, influenciado pelo clima da época, o anseio de superar o próprio individualismo adquiria uma dimensão tanto poética (e artística) quanto ideológica, o que obrigava nosso Autor a tratá-las em conjunto. O poema se insere precisamente nesse processo, e em sua oscilação condensa questões que - hoje sabemos - ocupariam Drummond por muito tempo ainda.

118 Cf. Vagner Camilo, "Brejo das almas: uma poética da indecisão". In: Novos estudos. São Paulo: CEBRAP, novembro 2006, pp. 39-47. 


\section{EPÍLOGO}

No mesmo momento em que publicava "Outubro 1930" pela primeira vez, em maio de 1931, Drummond afirmava em entrevista para o jornal A Pátria:

espiritualmente, a minha geração está diante de três rumos, ou de três soluções - Deus, Freud e o comunismo. A bem dizer, os rumos são dois apenas: uma ação católica, fascista e organizada em "Defesa do Ocidente" de um lado. E do outro lado o paraíso moscovita, com a sua terrível e por isso mesmo envolvente sedução. Que é um apelo a tudo quanto subsiste em nós de romântico e descontrolado. Mas entre as duas posições, que impõem duas disciplinas, há lugar para a simples investigação científica, que nos fornece a chave, e por assim dizer o perdão dos nossos erros mais íntimos e das nossas mais dolorosas perplexidades. 'Vamos todos para a Pasárgada' é o grito que Mário de Andrade ouviu de quase todas as nossas bocas, e creio que ouviu bem... Aqueles a quem o tomismo não consola, e o plano quinquenial não interessa, esses se voltam para a libertação do instinto, o supra-realismo e a explicação dos sonhos, no roteiro da psicanálise. Ao ceticismo, à disponibilidade, à não-opção sucede - nova moléstia do espírito - essa 'ida a Pasárgada', paraíso freudiano, onde o poeta Manuel Bandeira afirma que tem 'a mulher que eu quero, na cama que escolherei', além de muitas outras utilidades que correspondem à satisfação de muitos outros impulsos sequestrados. Quanto a minha posição pessoal diante desses três caminhos possíveis, creio que não interessa aos leitores de A Pátria ${ }^{119}$.

$\mathrm{Na}$ entrevista, o poeta mineiro traça um balanço amplo da sua geração e dos dilemas a serem enfrentados por ela. $\mathrm{O}$ núcleo da resposta reside na existência de diferentes caminhos a serem trilhados e, de maneira oblíqua, na necessidade de os seus companheiros de geração (e de ele próprio, obviamente) escolherem um entre eles. A resposta é significativa porque revela que no momento da entrevista Drummond ao que tudo indica não enxergava outras alternativas além das mencionadas (o catolicismo, a

\footnotetext{
${ }^{119}$ Apud John Gledson, Poesia e poética de Carlos Drummond de Andrade. São Paulo: Duas Cidades,
} 1981, pp. 90-91. 
psicanálise e o comunismo) e, mais ainda, que ignorava ou, pelo menos, não via com simpatia a possibilidade de uma não-opção. Na verdade, Drummond estava às voltas com essas questões de caráter ideológico há algum tempo. Com efeito, elas já estavam presentes em sua correspondência e em sua produção poética pelo menos desde janeiro de 1931, como procuramos sugerir no capítulo anterior através da análise de "Outubro 1930" e de uma carta destinada a Mário de Andrade. E essas questões o angustiavam tanto mais na medida em que ele próprio - endossando a necessidade de se engajar, como sugere a entrevista de 1931 - não conseguia se decidir por nenhum dos caminhos existentes. Daí a frustração disseminada em suas cartas e poemas do período, entre eles "Outubro 1930", cuja oscilação formal estava ligada tanto à busca por novos caminhos, quanto ao embaraço em aderir a algum deles, como vimos. Lida em seu contexto, portanto, a entrevista revela o esforço do Autor em discutir e aprofundar essas questões, que no mais íntimo configuravam uma crise pessoal, emperrando sua atividade poética, como ele confessaria em carta de janeiro de 1931 a Mário de Andrade. Digamos que, influenciado pelo clima da época e pela intensa movimentação ideológica que caracterizou a década de 30, Drummond absorvia e participava ativamente de um debate que estava na ordem do dia e para o qual vinha tentando achar uma saída em sua produção poética.

Em sua resposta para a entrevista, o poeta mineiro distingue três rumos disponíveis aos membros da sua geração, que àquela altura estava entrando nos trinta anos (como se sabe, Drummond nasceu em 1902): a religião, a psicanálise e o comunismo. Na verdade, os rumos existentes eram só dois: o catolicismo (associado ao fascismo) e o comunismo, porquanto a psicanálise não constituiria exatamente uma solução, mas uma "simples investigação científica". Seja como for, os dois rumos apontados pelo poeta mineiro atestam a impregnação difusa, porém vigorosa das preocupações sociais e religiosas no debate e na produção artística da década de 30, resultado da convivência íntima e da convergência surpreendente entre a literatura e as ideologias políticas e religiosas notadas por Antonio Candido em seu famoso ensaio "A revolução de 30 e a cultura". Na resposta que deu ao jornal, Drummond parece considerar o fascismo e o comunismo como sendo duas soluções simétricas, mas de sentidos opostos: tratava-se, de um lado, da defesa organizada do Ocidente; de outro, pelo contrário, de um apelo sedutor e terrível. Talvez por isso, por causa dessa aparência de soluções prontas, nosso Autor não tenha se detido muito em nenhuma delas e tenha se concentrado, ao invés, na psicanálise. $\mathrm{O}$ fato é que o destaque maior é dado a esta - cuja explicação ocupa a maior 
parte da resposta -, o que é curioso, porque não se trata de uma solução, mas de uma investigação capaz, segundo Drummond, de fornecer a chave e o perdão do modo de ser mais íntimo. Na acepção atribuída por ele, a psicanálise consistia em um instrumento apto para sondar os instintos, o supra-realismo, os sonhos, os impulsos sequestrados - enfim, o inconsciente e a subjetividade. O destaque dado à psicanálise se revela, portanto, profundamente coerente com a pesquisa aturada da subjetividade que marcou - como tentamos argumentar ao longo de todo este trabalho - a produção poética do poeta mineiro da década de 20. Ou por outra, o destaque dado a ela reflete não a sua adesão (afinal, ele se esquiva de esclarecer sua posição pessoal na entrevista), mas o seu interesse e inclinação pelas formas de sondagem da subjetividade. E de fato, a psicanálise devia parecer a ele naquele momento uma solução aceitável porque respondia às solicitações do acirrado debate ideológico da época e porque, ao mesmo tempo, não era incompatível com o seu próprio individualismo, do qual não conseguia se livrar. Tratava-se, em certo sentido, de uma solução de compromisso, através da qual o seu próprio individualismo podia ser conservado e explorado. Porém, a conservação do seu individualismo - mesmo sob a forma "científica" da psicanálise - não constituía para Drummond uma solução efetiva, tanto assim que ele a situava entre o que considerava soluções verdadeiras, o fascismo e o comunismo. Ou seja, o interesse pela psicanálise não configurava, aos seus olhos, uma solução, provavelmente porque ela o mantinha aprisionado em seu individualismo, com o qual ele queria romper por julgá-lo em desacordo com a atmosfera intelectual engajada do período (as "paragens largas e povoadas" mencionadas na carta a Mário) - daí possivelmente por que não aderia a ela.

Por sua vez, a alusão a Mário de Andrade revela a continuidade do diálogo iniciado em 1924. A referência da entrevista é ao ensaio "A poesia em 1930". Nele, eram analisados quatro livros de poesia publicados em 1930: Alguma poesia, de Drummond, Libertinagem, de Manuel Bandeira, O pássaro cego, de Augusto Frederico Schmidt, e Poesia, de Murilo Mendes. Sem prejuízo das diferenças e singularidades de cada um, Mário identificava em todos o que chamou de um espírito de vou-me embora, adaptando o famoso refrão do poema "Vou-me embora pra Pasárgada", de Manuel Bandeira. Segundo o argumento do ensaio, tratava-se de um estado de espírito vigente entre os poetas: "incapazes de achar a solução, surgiu neles essa vontade amarga de dar de ombros, de não se amolar, de partir pra uma farra de libertações morais e físicas de toda 


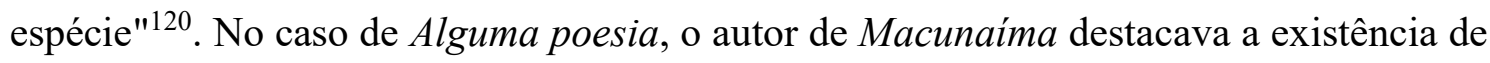
dois sequestros resultantes da reação do poeta mineiro contra sua "inenarrável capacidade para viver": um, sexual e outro - artisticamente mais importante, porque, de acordo com Mário, mais bem sublimado -, da vida besta. Ora, é justamente esse diagnóstico que Drummond cita e endossa na entrevista de 1931, inclusive com as mesmas palavras de "A poesia em 1930", destacando-se o termo "sequestro", àquela altura muito empregado por Mário e tomado de empréstimo pelo poeta mineiro. A recorrência dessas expressões de matriz psicanalítica (ainda que adaptadas e com sentidos insólitos) reflete a voga do debate ideológico e sua refração na obra de Mário do período, que promoveu uma espécie de "ajustamento ideológico"121 entre cristianismo, marxismo e psicanálise - não por acaso, as mesmas tendências citadas por Drummond na entrevista. Na verdade, o interesse deste pela psicanálise - como tantas outras coisas - foi ao que parece incutido pelo amigo paulista, que talvez tenha sido o primeiro a chamar sua atenção para a convergência subterrânea existente entre o seu livro de estreia e a psicanálise, com a crônica "Puro, sem mistura", de junho de $1930^{122}$. De sua parte, nosso Autor parece ter concordado com Mário e se interessado verdadeiramente pelo tema - sem, contudo, abraçá-lo de maneira irrestrita. De fato, as suas referências ao surrealismo e à psicanálise nesse período, como afirma John Gledson, "não são [...] de um aderente. Interessa-se [...] como sintomas, e não soluções"123. Ou por outra, embora se valesse do vocabulário e de um diagnóstico de extração psicanalítica e psicologizante (o "voumeemborismo" de Mário), o poeta mineiro relutava em se engajar nela, porque não tinha atingido ainda a "maturação necessária"124, segundo confessou em carta. Talvez não fosse só isso. Como estamos tentando argumentar, Drummond não considerava a psicanálise uma solução porque ela o

\footnotetext{
${ }^{120}$ Mário de Andrade, “A poesia em 1930". In: Aspectos da literatura brasileira. São Paulo: Martins, 1974, p. 31.

${ }^{121}$ A expressão é de Telê Porto Ancona Lopez, Cf. da Autora, Mário de Andrade: ramais e caminhos. São Paulo: Livraria Duas Cidades, 1972, p. 65. A expressão é usada especificamente para a combinação de Cristianismo e Marxismo, mas também vale - acho eu - para a psicanálise, haja vista a presença no vocabulário de Mário de expressões tomadas dela.

122 É muito provável que Drummond já conhecesse a psicanálise antes mesmo da crônica da Mário, inclusive porque ela foi tema de artigos publicados na revista que o poeta mineiro editou junto com nomes como João Alphonsus e Emílio Moura. Mas - esta é a hipótese desenvolvida aqui -, ele só passou a vê-la como uma solução possível para a sua própria crise poética e ideológica após o alerta dado por Mário em "Puro, sem mistura". A indicação da existência desses artigos foi lembrada por Ivan Marques, a quem agradeço.

123 John Gledson, op. cit., p. 91

${ }^{124}$ Lélia Coelho (org.), Carlos \& Mário: correspondência completa entre Carlos Drummond de Andrade inédita - e Mário de Andrade. Rio de Janeiro: Bem-Te-Vi, 2002, p. 402.
} 
mantinha agrilhoado ao seu individualismo, o qual lhe parecia suficientemente trabalhado nos poemas de Alguma poesia. Estimulado pelo efervescente cenário intelectual da época e em busca de novos rumos poéticos, a insistência nos mesmos assuntos assumia para o poeta mineiro a feição de um decepcionante girar em círculo, do qual não conseguia escapar e para o qual não via outra saída senão se engajar. E é dessa tensão fundamental que se alimentará parte considerável da poesia de Drummond escrita nas décadas de 30 e 40.

Exceto pelo fato de também ter sido publicada em jornal, a entrevista de 1931 guarda poucas semelhanças com o artigo de Drummond de 1925 estampado no "Mês modernista". Porque, diferentemente do ânimo polêmico e engraçadinho de "Ta'i!", a entrevista se caracteriza pelo cunho analítico e argumentativo. A diferença se explica pelos objetivos de cada um. Afinal, se em "Ta'i!" o que estava em jogo era sobretudo a legitimidade estética do Modernismo, na entrevista se tratava de discutir os impasses do movimento, àquela altura praticamente consolidado. Daí que o artigo, inserido em um momento de combate, empregasse as mesmas armas das vanguardas - especialmente, o choque e o humor -, ao passo que a entrevista, situada em águas inquietantemente calmas, preferisse a ponderação e a sobriedade. Ou por outra, quando da entrevista em 1931, Drummond está muito distante do jovem autor de "Ta'i!" e de suas preocupações em torno da validade estética do Modernismo. Influenciado pela radicalização do debate ideológico da época, ele discute na entrevista os caminhos que se apresentavam a seus companheiros de geração e luta. Tratava-se, assim, de interrogar o destino das aspirações e inovações modernistas pelas quais ele havia se batido no artigo de 1925 e que, na virada da década, começaram a se normalizar. Portanto, entre as questões do artigo e as da entrevista há, não ruptura, mas um processo de redimensionamento, em que a discussão estética e artística do primeiro incorpora, na segunda, conotações ideológicas mais explícitas. A despeito das diferenças de superfície, por conseguinte, há uma continuidade profunda e estrita entre um e outra, porque ambos constituem em última análise intervenções dentro de um mesmo debate - o debate modernista -, ainda que se situem em momentos muito distintos dele. Nesse sentido, os dois se relacionam ao esforço do Autor de participar das questões do seu tempo. Na verdade, tanto o artigo de 1925 quanto a entrevista de 1931 possuem uma dimensão programática que os aproxima: em um, o poeta mineiro reelabora 
e ressignifica a ausência de uma tradição autêntica, tratando como potencialidade o que era usualmente encarado como carência; e em outra, exorta seus companheiros a se engajarem, problematizando indiretamente sua própria indecisão ideológica.

A dimensão estratégica comum ao artigo e à entrevista testemunha, além disso, que, a despeito do individualismo confessado de Drummond, sua voz poética se definiu a partir do diálogo cerrado (que não exclui o confronto e a polêmica) com autores especialmente com a figura de proa do Modernismo, Mário de Andrade -, questões e temas candentes da época. E esse diálogo é tanto mais cerrado e, por isso mesmo, visível no intervalo que separa a publicação do artigo do aparecimento da entrevista, na medida em que ele constitui o coração da temporada de formação do poeta mineiro, como ele próprio assumiria em carta a Mário. Com efeito, é nesse intervalo em que foi escrita a maioria dos poemas depois reunidos em Alguma poesia e em que o poeta mineiro logrou forjar uma voz poética pessoal, nacional e moderna. O que não quer dizer, é claro, que a formação do Poeta tenha se completado nesse intervalo (como não se formou a sociedade correspondente), afinal a grande marca de fábrica da sua lírica são, como se sabe, justamente, as inquietudes poéticas, que divergem inteiramente da plenitude e imobilidade sugeridas pela ideia de formação. Como procuramos mostrar, as questões trabalhadas ao longo da década de 20 não foram resolvidas ou abandonadas na década seguinte, mas deslocadas e retrabalhadas em um âmbito mais explicitamente ideológico, em um processo truncado e cheio de idas e vindas, mas significativo e, em certo sentido, atual. Pois, embora os poemas de seu livro de estreia estejam rigorosamente inseridos em seu contexto - como procuramos enfatizar ao longo das análises -, eles mantêm seu interesse em boa medida graças à mediação de uma subjetividade hipertrofiada e tirânica, reinventada literariamente com o uso em geral original das conquistas modernistas, que pareciam corresponder à natureza poética mais recôndita de Drummond, como notou Antonio Candido $^{125}$. Via de regra, essa subjetividade está implicada e se analisa a si mesma nos poemas, compondo uma sondagem introspectiva e prismática. A participação nas questões e polêmicas da época não constitui, portanto, obstáculo à autonomia e à pureza da poética do seu primeiro livro, pelo contrário: essas categorias são internalizadas e problematizadas desde dentro, em um movimento poético analítico e mesclado que relativiza e tensiona as convenções líricas clássicas. Aí a modernidade de Alguma poesia,

${ }^{125}$ Antonio Candido, Iniciação à literatura brasileira. Rio de Janeiro: Ouro sobre Azul, p. 101. 
cujo individualismo incrustado equivale, não a alheamento ou isolamento, mas a um meio, muitas vezes irônico e engraçado, de conhecimento da realidade. A subjetividade que emerge do conjunto se abre, assim, para a objetividade, absorvendo-a e a recriando liricamente.

E se hoje, em tempos pós-catastróficos, a subjetividade poderosa configurada nos poemas de Alguma poesia está porventura distante de nós e possui algo de uma miragem ${ }^{126}$, talvez o livro ganhe em ser lido como uma espécie de imagem, acima de tudo crítica, do que poderíamos ter sido, e não fomos, barrados pelo rumo desconcertante dos acontecimentos, que continuam nos interrogando.

\footnotetext{
${ }^{126}$ Comentando o diálogo de um livro contemporâneo de poesia, Corola da poetisa Claudia RoquettePinto, com o lirismo intimista de Claro enigma, de Drummond, Iumna Maria Simon e Vinicius Dantas afirmam que: "Claudia Roquette-Pinto não se apropria desses temas ou técnicas para glosá-los, uma vez que está ciente do quanto a poderosa subjetividade drummondiana é inviável nas circunstâncias atuais. Corola testemunha a inviabilidade de um sujeito capaz de delinear os terrenos do eu e do outro, da intimidade e da sociedade e ainda dizer classicamente a hora histórica de seu desmoronamento, ou fracasso. Nesse caso, ou noutros de diálogos diretos ou indiretos, a autora de Corola tem noção de que a sua consciência crítica é específica, limitada a seus materiais, a seus processos de composição, o que lhe diminui a envergadura, sem comprometer a qualidade de sua poesia". Iumna Maria Simon e Vinicius Dantas, "Consistência de Corola". In: Novos Estudos. São Paulo: CEBRAP, no 85 , novembro 2009, p. 216. Ou seja, a atualidade da subjetividade drummondiana se revela em negativo, como uma espécie de avesso do estado de coisas atual.
} 


\section{BIBLIOGRAFIA}

ANDRADE, Carlos Drummond de. Confissões de Minas. São Paulo: Cosac Naify, 2011 - Poesia 1930/62. Organização Júlio Castañon

Guimarães, São Paulo: Cosac Naify, 2012.

. Poesia e prosa, Rio de Janeiro: Editora Nova

Aguilar, 1992.

ANDRADE, Luciana Teixeira de. A Belo Horizonte dos modernistas: representações ambivalentes da cidade moderna. Belo Horizonte: PUC Minas: C/Arte, 2004.

ANDRADE, Mário de. Aspectos da Literatura Brasileira. São Paulo: Martins, 1960.

. O empalhador de passarinho. São Paulo: Martins, 1972.

. Poesias completas. Edição crítica de Diléia Zanotto Manfio, Belo

Horizonte; São Paulo: Itatiaia; Editora da Universidade de São Paulo, 1987

. Táxi e crônicas no Diário Nacional. Estabelecimento de texto, introdução e notas Telê Porto Ancona, São Paulo: Livraria Duas Cidades, 1976.

ANDRADE, Oswald de. Pau Brasil, São Paulo: Globo, 2004.

ARANTES, Otília e Paulo. Sentido da formação: três estudos sobre Antonio Candido, Gilda de Mello e Lúcio Costa. Rio de Janeiro: Paz e Terra, 1997.

ARRIGUCCI JR., Davi. Coração Partido - uma análise da poesia reflexiva de Drummond. São Paulo: Cosac Naify, 2008.

ASSIS, Machado de. Obras completas. Rio de Janeiro: Editora Nova Aguilar, 1996.

BANDEIRA, Manuel. Crônicas da província Brasil. São Paulo: Cosac Naify, 2011. Poesia completa e prosa. Rio de Janeiro: Editora Nova Aguilar, 1985.

BATISTA, Marta Rossetti, LOPEZ, Telê Porto Ancona e LIMA, Yone Soares de (orgs.). 
Brasil: $1^{\circ}$ Tempo Modernista - 1917/29. São Paulo: Instituto de Estudos Brasileiros, 1972.

CAMILO, Vagner. "A cartografia lírico-social de Sentimento do mundo", in: Revista USP. São Paulo, março/maio, no 53, 2002, pp. 64-75.

. "Brejo das almas: uma poética da indecisão". In: Novos estudos. São

Paulo: CEBRAP, novembro 2006, pp. 39-47.

. Drummond: da Rosa do Povo à rosa das trevas. Cotia: Ateliê

Editorial/Anpoll, 2001.

. "Figurações espaciais e mapeamentos na lírica de Drummond", in:

ReDObRa, v. 13, 2014, pp. 35-66.

CANÇADO, José Maria. Os sapatos de Orfeu: biografia de Carlos Drummond de Andrade. São Paulo: Ed. Página Aberta Ltda, 1993.

CANDIDO, Antonio. A educação pela noite. Rio de Janeiro: Ouro sobre Azul, 2011. . Iniciação à literatura brasileira. Rio de Janeiro: Ouro sobre Azul, 2010

. Literatura e sociedade: estudos de história e teoria literária, Rio de Janeiro: Ouro sobre Azul, 2011.

. O discurso e a cidade. Rio de Janeiro: Ouro sobre Azul/ Academia Brasileira de Letras, 2010.

. Recortes. São Paulo: Companhia das Letras, 1993.

. Vários escritos. Rio de Janeiro: Ouro sobre Azul, 2011.

COELHO (org.), Lélia. Carlos \& Mário: correspondência entre Carlos Drummond de Andrade - inédita - e Mário de Andrade: 1924-1945. Rio de Janeiro: Bem-Te-Vi, 2002.

COSTA, Iná Camargo. "A herança modernista nas mãos do primeiro Drummond", in: Ana Pizarro (org.), América Latina: palavra, literatura e cultura. V. 3. Campinas/São Paulo: Memorial/UNICAMP, 3 vols., 1995, pp. 309-318.

CURY, Maria Zilda. Horizonte Modernistas: o jovem Drummond e seu grupo em papel jornal. Belo Horizonte: Autêntica, 1998. 
DANTAS, Vinicius. "Desmanchando o naturalismo: capítulos obscuríssimos da crítica de Mário e Oswald", Novos Estudos. São Paulo: CEBRAP, nº 57, julho 2000, pp. 9-27. . "Entre "A negra" e a mata virgem", in: Novos Estudos. São Paulo: CEBRAP, no 45, julho 1996, pp. 100-116.

. "Oswald de Andrade e a poesia", in: Novos Estudos. São Paulo: CEBRAP, no 30, julho 1991, pp. 191-203.

GLEDSON, John. Influências e impasses: Drummond e alguns contemporâneos. São Paulo: Companhia das Letras, 2003.

. Poesia e poética de Carlos Drummond de Andrade. São Paulo: Duas Cidades, 1981.

GOLDSTEIN, Norma. Do Penumbrismo ao Modernismo: o primeiro Bandeira e outros poetas significativos. São Paulo: Ática, 1983.

HOLANDA, Sérgio Buarque de. O espírito e a letra: estudos de crítica literária 19481959. Vol. 2. Org. Antonio Arnoni Prado, São Paulo: Companhia das Letras, 1996.

LOPEZ, Telê Porto Ancona. Mário de Andrade: ramais e caminhos. São Paulo: Livraria Duas Cidades, 1987.

MARQUES, Ivan. Cenas de um modernismo de província: Drummond e outros rapazes de Belo Horizonte. São Paulo: Editora 34, 2011.

. "Modernismo de pés descalços: Mário de Andrade e a cultura caipira", in: Revista IEB, São Paulo, nº 55, 2012, pp. 27-42.

. "O país dos Andrades: Drummond e o Brasil profundo". In: Cerrados (UnB), v. 17, p. 93-110, 2008.

MELlO E SOUZA, Gilda de. A ideia e o figurado. São Paulo: Livraria Duas Cidades/Editora 34, 2005.

Exercícios de Leitura. São Paulo: Duas Cidades, 1980.

. O tupi e o alaúde. São Paulo: Duas Cidades/Editora 34, 2003.

MERQUIOR, José Guilherme. Verso universo em Drummond. Rio de Janeiro: José 
Olympio, 1976.

MORAES, Marcos Antonio de (org.). Correspondência: Mário de Andrade \& Manuel Bandeira. São Paulo: EDUSP; IEB, 2001.

PASINI, Leandro. Apreensão do desconcerto: subjetividade e nação na poesia de Mário de Andrade. Tese de Doutorado, FFLCH-USP, 2011.

RUFINONI, Simone Rossinetti. "Mário e Drummond: nacionalismo, alteridade, arte”, in: Estudos Avançados (USP), v. 80, 2014, pp. 247-264.

SCHWARZ, Roberto. Ao vencedor as batatas: forma literária e processo social nos inícios do romance brasileiro. São Paulo: Livraria Duas Cidades/Editora 34, 2000. . A sereia e o desconfiado: ensaios crítico, Rio de Janeiro: Paz e Terra, 1981. . Martinha versus Lucrécia: ensaios críticos. São Paulo: Companhia das Letras, 2012 . O pai de família e outros ensaios. Rio de Janeiro: Paz e Terra, 1978. . Que horas são?. São Paulo: Companhia das Letras, 1997. . Sequências brasileiras: ensaios. São Paulo: Companhia das Letras, 1999.

SIMON, Iumna Maria. "Condenados à tradição", in: Piauí, no 61, outubro 2011, pp. 8286. . "Considerações sobre a poesia brasileira em fim de século", in: Novos Estudos. São Paulo: CEBRAP, no 55, novembro 1999, pp. 27-36.

; DANTAS, Vinicius, "Consistência de Corola". In: Novos Estudos. São Paulo: CEBRAP, no 85, novembro 2009, pp. 215-235. . Drummond - Uma poética do risco. São Paulo: Ática, 1978. . "Na praça de convites", in: SCHWARZ (org.), Roberto. Os pobres na literatura brasileira. São Paulo: Brasiliense, 1983, pp. 140-148. . "O mundo em chamas e o país inconcluso", in: Novos Estudos. São 
Paulo: CEBRAP, n $^{\circ}$ 103, novembro 2015, pp. 169-191.

SINGER, Paul. Desenvolvimento econômico e evolução urbana. São Paulo: Editora Nacional, 1968.

VILLAÇA, Alcides. Passos de Drummond. São Paulo: Cosac Naify, 2006. 